\title{
New Titanium Borylimido Compounds: Synthesis, Structure, and Bonding
}

\author{
Benjamin A. Clough, ${ }^{\dagger}$ Simona Mellino, ${ }^{\dagger}$ Andrey V. Protchenko, ${ }^{\dagger}$ Martin Slusarczyk, ${ }^{\dagger}$ Laura C. Stevenson, $^{\dagger}$
} Matthew P. Blake, ${ }^{\dagger}$ Bowen Xie, ${ }^{\dagger}$ Eric Clot, ${ }^{*}+\infty$ and Philip Mountford ${ }^{*}{ }^{\dagger}$ (i)

${ }^{\dagger}$ Chemistry Research Laboratory, Department of Chemistry, University of Oxford, Mansfield Road, Oxford OX1 3TA, U.K.

${ }^{\ddagger}$ Institut Charles Gerhardt Montpellier, UMR 5253, CNRS-UM-ENSCM, Université de Montpellier, cc 1501, Place Eugéne Bataillon, F-34095 Montpellier Cedex 5, France

Supporting Information

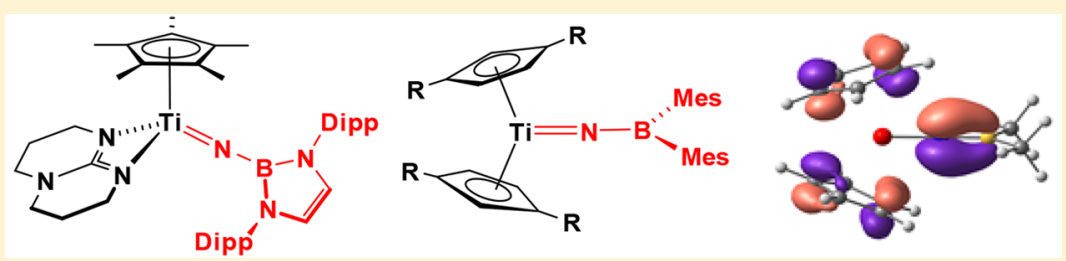

ABSTRACT: We report a combined experimental and computational study of the synthesis and electronic structure of titanium borylimido compounds. Three new synthetic routes to this hitherto almost unknown class of Group 4 imide are presented. The double-deprotonation reaction of the borylamine $\mathrm{H}_{2} \mathrm{NB}\left(\mathrm{NAr}{ }^{\prime} \mathrm{CH}\right)_{2} \quad\left(\mathrm{Ar}^{\prime}=2,6-\mathrm{C}_{6} \mathrm{H}_{3}{ }^{\mathrm{i}} \mathrm{Pr}_{2}\right)$ with $\mathrm{Ti}\left(\mathrm{NMe}_{2}\right)_{2} \mathrm{Cl}{ }_{2}$ gave $\mathrm{Ti}\left\{\mathrm{NB}\left(\mathrm{NAr}^{\prime} \mathrm{CH}\right)_{2}\right\} \mathrm{Cl}_{2}\left(\mathrm{NHMe}_{2}\right)_{2}$, which was easily converted to $\mathrm{Ti}\left\{\mathrm{NB}\left(\mathrm{NAr}{ }^{\prime} \mathrm{CH}\right)_{2}\right\} \mathrm{Cl}_{2}(\mathrm{py})_{3}$. This compound is an entry point to other borylimides, for example, reacting with $\mathrm{Li}_{2} \mathrm{~N}_{2}{ }^{\text {pyr }} \mathrm{N}^{\mathrm{Me}}$ to form $\mathrm{Ti}\left(\mathrm{N}_{2}{ }^{\text {pyr }} \mathrm{N}^{\mathrm{Me}}\right)\left\{\mathrm{NB}\left(\mathrm{NAr}{ }^{\prime} \mathrm{CH}\right)_{2}\right\}(\mathrm{py})_{2}$ and with 2 equiv of $\mathrm{NaCp}$ to give $\mathrm{Cp}_{2} \mathrm{Ti}\left\{\mathrm{NB}\left(\mathrm{NAr}{ }^{\prime} \mathrm{CH}\right)_{2}\right\}(\mathrm{py})$ (23). Borylamine-tert-butylimide exchange between $\mathrm{H}_{2} \mathrm{NB}\left(\mathrm{NAr} \mathrm{r}^{\prime} \mathrm{CH}\right)_{2}$ and $\mathrm{Cp}^{*} \mathrm{Ti}\left(\mathrm{N}^{\mathrm{t}} \mathrm{Bu}\right) \mathrm{Cl}(\mathrm{py})$ under forcing conditions afforded $\mathrm{Cp}{ }^{*} \mathrm{Ti}\left\{\mathrm{NB}\left(\mathrm{NAr} \mathrm{C}^{\prime} \mathrm{CH}\right)_{2}\right\} \mathrm{Cl}(\mathrm{py})$, which could be further substituted with

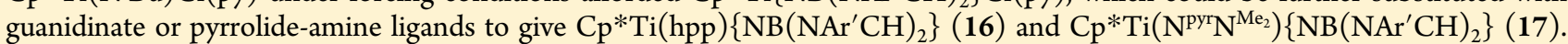
The $\mathrm{Ti}-\mathrm{N}_{\mathrm{im}}$ distances in compounds with the $\mathrm{NB}\left(\mathrm{NAr} \mathrm{r}^{\prime} \mathrm{CH}\right)_{2}$ ligand were comparable to those of the corresponding arylimides. Dialkyl- or diaryl-substituted borylamines do not undergo the analogous double-deprotonation or imide-amine exchange reactions. Reaction of $\left(\mathrm{Cp}^{\prime \prime}{ }_{2} \mathrm{Ti}\right)_{2}\left(\mu_{2}: \eta^{1}, \eta^{1}-\mathrm{N}_{2}\right)$ with $\mathrm{N}_{3} \mathrm{BMes}_{2}$ gave the base-free, diarylborylimide $\mathrm{Cp}{ }_{2}{ }_{2} \mathrm{Ti}\left(\mathrm{NBMes}_{2}\right)(26)$ by an oxidative route; this compound has a relatively long $\mathrm{Ti}-\mathrm{N}_{\mathrm{im}}$ bond and large $\mathrm{Cp}^{\prime \prime}-\mathrm{Ti}-\mathrm{Cp}^{\prime \prime}$ angle. Reaction of 16 with $\mathrm{H}_{2} \mathrm{~N}^{t} \mathrm{Bu}$ formed equilibrium mixtures with $\mathrm{H}_{2} \mathrm{NB}\left(\mathrm{NAr}{ }^{\prime} \mathrm{CH}\right)_{2}$ and $\mathrm{Cp}{ }^{*} \mathrm{Ti}(\mathrm{hpp})\left(\mathrm{N}^{\mathrm{t} B u}\right)\left(\Delta_{\mathrm{r}} G=-1.0 \mathrm{kcal}^{\mathrm{mol}}{ }^{-1}\right)$. In contrast, the dialkylborylimide $\mathrm{Cp}^{*} \mathrm{Ti}\left\{\mathrm{MeC}\left(\mathrm{N}^{\mathrm{i}} \mathrm{Pr}\right)_{2}\right\}\left(\mathrm{NBC}_{8} \mathrm{H}_{14}\right)$ (2) reacted quantitatively with $\mathrm{H}_{2} \mathrm{~N}^{\mathrm{t}} \mathrm{Bu}$ to give the corresponding tertbutylimide and borylamine. The electronic structures and imide-amine exchange reactions of half-sandwich and sandwich titanium borylimides have been evaluated using density functional theory (DFT), supported by quantum theory of atoms in molecules (QTAIM) and natural bond orbital (NBO) analysis, and placed more generally in context with the well-established alkyl- and arylimides and hydrazides. The calculations find that $\mathrm{Ti}-\mathrm{N}_{\mathrm{im}}$ bonds for borylimides are stronger and more covalent than in their organoimido or hydrazido analogues, and are strongest for alkyl- and arylborylimides. Borylamine-tert-butylimide exchange reactions fail for $\mathrm{H}_{2} \mathrm{NBR}_{2}$ ( $\mathrm{R}$ = hydrocarbyl) but not for $\mathrm{H}_{2} \mathrm{NB}\left(\mathrm{NAr}{ }^{\prime} \mathrm{CH}\right)_{2}$ because the increased strength of the new $\mathrm{Ti}-\mathrm{N}_{\mathrm{im}}$ bond for the former is outweighed by the increased net $\mathrm{H}-\mathrm{N}$ bond strengths in the borylamine. Variation of the Ti- $\mathrm{N}$ im bond length over short distances is dominated by $\pi$-interactions with any appropriate orbital on the $\mathrm{N}_{\mathrm{im}}$ atom organic substituent. However, over the full range of imides and hydrazides studied, overall bond energies do not correlate with bond length but with the $\mathrm{Ti}-\mathrm{N}_{\mathrm{im}} \sigma$-bond character and the orthogonal $\pi$-interaction.

\section{INTRODUCTION}

As summarized in several reviews, ${ }^{1}$ the synthesis, bonding, and reactivity of Group 4 terminal organoimido complexes (L)M(NR) ( $\mathrm{M}=$ Group 4 metal, $\mathrm{R}=$ alkyl or aryl) have seen considerable activity since Bergman, Wolczanski, Rothwell, and Roesky's initial reports in these areas. ${ }^{2}$ The polar and unsaturated $\mathrm{M}-\mathrm{N}_{\mathrm{im}}$ multiple bond (formally a $\sigma^{2} \pi^{4}$ triple bond in most instances ${ }^{3}$ ) usually acts as the reactive site in these complexes and can undergo a wide range of addition reactions with saturated and unsaturated substrates. In addition to the continuing interest in Group 4 imido chemistry, the past 10 years in particular have seen a number of advances in the corresponding dialkyl- or diarylhydrazido(2-) complexes (L) $\mathrm{M}\left(\mathrm{NNR}_{2}\right)(\mathrm{M}=\text { Group } 4, \mathrm{R}=\text { alkyl or aryl })^{4}$ where the hydrocarbyl $\mathrm{N}_{\mathrm{im}}$-substituent of an organoimido group is replaced by a heteroatom donor. This chemistry, following from initial reports by Wiberg $^{5}$ and Bergman, ${ }^{4 \mathrm{~b}}$ is also characterized by single or multiple coupling or insertion reactions of the $\mathrm{M}-\mathrm{N}_{\mathrm{im}}$ bond. On reaction with reducing

Received: July 19, 2017

Published: August 24, 2017 

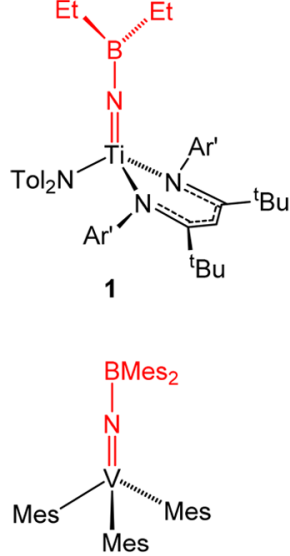

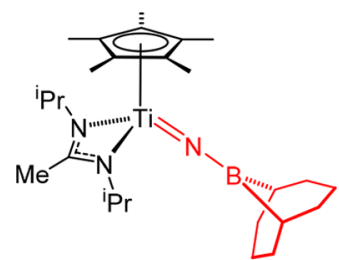

2

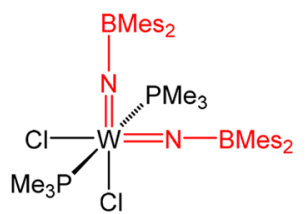

5

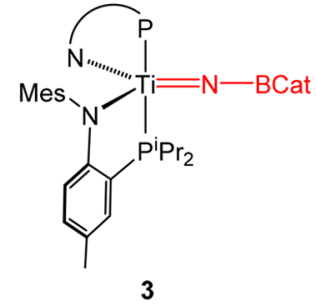

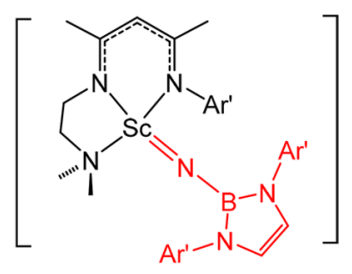

Figure 1. Isolated and transient terminal borylimido complexes of Groups 3-6. $\mathrm{Ar}^{\prime}=2,6-\mathrm{C}_{6} \mathrm{H}_{3}{ }^{\mathrm{i}} \mathrm{Pr}_{2}, \mathrm{Mes}=2,4,6-\mathrm{C}_{6} \mathrm{H}_{2} \mathrm{Me} \mathrm{e}_{3}, \mathrm{~N} \cdots \mathrm{P}=\mathrm{MesN}-1,2-$ $\mathrm{C}_{6} \mathrm{H}_{4} \mathrm{P}^{\mathrm{i}} \mathrm{Pr}_{2}, \mathrm{BCat}=\mathrm{B}\left(1,2-\mathrm{O}_{2} \mathrm{C}_{6} \mathrm{H}_{4}\right) \cdot{ }^{4 \mathrm{q}, 10-13,15}$

substrates such as alkynes, $\mathrm{CO}$, and isonitriles, cleavage of the $\mathrm{N}_{\mathrm{im}}-\mathrm{NR}_{2}$ bond can also occur. In further development of heteroatom-functionalized imido compounds we showed that the corresponding alkoxyimido, (L)Ti(NOR), chemistry can also be readily accessed, leading in certain cases to reductive $\mathrm{N}_{\mathrm{im}}-\mathrm{O}$ bond cleavage and/or $\mathrm{Ti}-\mathrm{N}_{\mathrm{im}}$ addition and coupling reactions. ${ }^{6}$

The $\mathrm{N}_{\mathrm{im}}$-bound heteroatom donors in hydrazido and alkoxyimido compounds perturb the bonding in the $\mathrm{Ti}-\mathrm{N}_{\mathrm{im}}$ bond itself by acting as lone pair $(\pi)$ donors to one of the Ti$\mathrm{N}_{\mathrm{im}} \pi^{*}$ MOs $(\mathrm{MO}=$ molecular orbital), and also destabilizing one of the $\mathrm{Ti}-\mathrm{N}_{\mathrm{im}} \pi$-bond MOs. We have reported density functional theory (DFT) and natural bond orbital $(\mathrm{NBO})^{7}$ studies of these effects, including the cyclopentadienylamidinate complexes $\mathrm{Cp}{ }^{*} \mathrm{Ti}\left\{\mathrm{MeC}\left(\mathrm{N}^{\mathrm{i} P r}\right)_{2}\right\}(\mathrm{NR})$ ( $\mathrm{R}=$ hydrocarbyl, $\mathrm{NR}_{2}^{\prime}$ or $\mathrm{OR}^{\prime}$ ), which can be prepared for a range of imido and related functional groups. ${ }^{3 \mathrm{~h}, 4 \mathrm{r}, 6 \mathrm{~b}, 8}$

In contrast to this well-developed literature for Group 4 organoimido, hydrazido, and alkoxyimido chemistry, very little indeed is known about borylimido compounds $(\mathrm{L}) \mathrm{Ti}\left(\mathrm{NBR}_{2}\right)$ ( $\mathrm{R}=$ hydrocarbyl or heteroatom donor moiety). These feature a strongly $\sigma$-donating ${ }^{9}$ but $\pi$-accepting $\mathrm{BR}_{2}$ substituent at $\mathrm{N}_{\text {im }}$. The first Group 4 borylimide was Mindiola's 1 (Figure 1) formed unexpectedly from the corresponding parent imide (i.e., terminal $\mathrm{NH}$ ) with 2 equiv of $\mathrm{NaHBEt}_{3}{ }^{10}$. We subsequently reported the formation of a second titanium borylimide, namely, $\mathrm{Cp} * \mathrm{Ti}\left\{\mathrm{MeC}\left(\mathrm{N}^{\mathrm{i}} \mathrm{Pr}\right)_{2}\right\}\left(\mathrm{NBC}_{8} \mathrm{H}_{14}\right) \quad(2 \text {, Figure } 1)^{4 \mathrm{q}}$ through the serendipitous reductive $\mathrm{N}_{\mathrm{im}}-\mathrm{NR}_{2}$ bond cleavage reaction of the hydrazides $\mathrm{Cp}{ }^{*} \mathrm{Ti}\left\{\mathrm{MeC}\left(\mathrm{N}^{\mathrm{i} P r}\right)_{2}\right\}\left(\mathrm{NNR}_{2}\right)(\mathrm{R}=$ $\mathrm{Me}$ or $\mathrm{Ph})$ with $9-\mathrm{BBN}$. Very recently a catechol-functionalized borylimide 3 was obtained by reaction of a rare metalated nitride with ClBCat. ${ }^{11}$ There are only very few other transition metal borylimides known. Wilkinson and Sundermeyer have reported the synthesis of Group 5 and 6 dimesitylborylimides (e.g., 4 and 5 in Figure 1) by the oxidative reaction of lower oxidation state precursors with $\mathrm{N}_{3} \mathrm{BMes}_{2}{ }^{12}$ and Fryzuk et al. prepared a ditantalum borylimide by reaction of $9-\mathrm{BBN}$ with a dinitrogen compound. ${ }^{13}$ Our group very recently extended borylimido chemistry to Group 3 by using the bulky borylamine $\mathrm{H}_{2} \mathrm{NB}\left(\mathrm{NAr}^{\prime} \mathrm{CH}\right)_{2} \quad(\mathbf{6})^{14}$ to access the methylborylamide $\left(\mathrm{NacNac}^{\mathrm{NMe}_{2}}\right) \mathrm{Sc}(\mathrm{Me})\left\{\mathrm{NHB}\left(\mathrm{NAr}{ }^{\prime} \mathrm{CH}\right)_{2}\right\} .{ }^{15}$ Thermolysis led to methane elimination and formation of the transient borylimide 7 (Figure 1, neither isolated nor observed) which was trapped by $[2+2]$ cycloaddition or $\mathrm{C}-\mathrm{H}$ bond activation reactions. These are the first substrate-activation reactions of any metal-bound borylimide, although a number of interesting reports have appeared in the past decade concerning the small molecule activation reactions of transient borylnitrenes (generated from azide precursors). ${ }^{16}$

Encouraged by these recent results we set out to develop new routes to titanium borylimido compounds using $\mathrm{H}_{2} \mathrm{NB}$ $\left(\mathrm{NAr}^{\prime} \mathrm{CH}\right)_{2}$ as a representative heteroatom-substituted borylamine, and $\mathrm{H}_{2} \mathrm{NBC}_{8} \mathrm{H}_{14}$ and $\mathrm{H}_{2} \mathrm{NBMes}_{2}$ as organoborylamine analogues. In addition to extending the range of known titanium borylimides and developing useful synthetic routes for the future, we aimed to gain a better understanding of the bonding in these types of compound, both per se and in the wider context of the much better-established organoimido and hydrazido analogues.

\section{RESULTS AND DISCUSSION}

Synthesis of Bis(amine) and Tris(pyridine) Titanium Borylimido Compounds. One aim of this work was to establish the scope and potential of general synthetic entry points to titanium borylimido chemistry to complement those we have demonstrated previously for their organoimido, ${ }^{1 \mathrm{c}, \mathrm{e}, 17}$ hydrazido, $^{3 \mathrm{~h}, 41,8 \mathrm{a}, 18}$ and alkoxyimido ${ }^{6 \mathrm{a}, \mathrm{b}, \mathrm{d}}$ analogues. Bis(dimethylamine) and tris(pyridine) compounds of the type $\mathrm{Ti}(\mathrm{NR}) \mathrm{Cl}_{2}\left(\mathrm{NHMe}_{2}\right)_{2}$ and $\mathrm{Ti}(\mathrm{NR}) \mathrm{Cl}_{2}(\mathrm{py})_{3}$ ( $\mathrm{R}=$ alkyl, aryl, $\mathrm{NR}_{2}^{\prime}\left(\mathrm{R}^{\prime}=\mathrm{Me}\right.$ and/or $\left.\mathrm{Ph}\right)$ or $\left.\mathrm{O}^{\mathrm{t}} \mathrm{Bu}\right)$ have been particularly useful since substitution of one or more of the chloride and/or amine/pyridine ligands by other ligand sets is generally straightforward. The tris(pyridine) compounds can usually be accessed from their bis(dimethylamine) homologues. These, in turn, can be straightforwardly prepared by reaction of $\mathrm{Ti}\left(\mathrm{NMe}_{2}\right)_{2} \mathrm{Cl}_{2}$ with the respective primary amine, aniline, hydrazine, or tert-butoxyamine. We sought to extend these routes to borylamines $\mathrm{H}_{2} \mathrm{NBR}_{2}$ where $\mathrm{R}$ is either an $\mathrm{N}$-donor or C-donor substituent.

The N,N-disubstituted borylamine $\mathrm{H}_{2} \mathrm{NB}\left(\mathrm{NAr}^{\prime} \mathrm{CH}\right)_{2}(6)$ is readily available in multigram quantities, ${ }^{14}$ and was very successfully employed in accessing scandium borylimido chemistry. ${ }^{15}$ Reaction of 6 with $\mathrm{Ti}\left(\mathrm{NMe}_{2}\right)_{2} \mathrm{Cl}_{2}$ on the NMR tube scale in $\mathrm{C}_{6} \mathrm{D}_{6}$, quantitatively formed the borylimido 
Scheme 1. Synthesis of $\operatorname{Ti}\left\{\mathrm{NB}\left(\mathrm{NAr} \mathbf{r}^{\prime} \mathrm{CH}\right)_{2}\right\} \mathrm{Cl}_{2}\left(\mathrm{NHMe}_{2}\right)_{2}(8)$ and $\mathrm{Ti}\left\{\mathrm{NB}\left(\mathrm{NAr}^{\prime} \mathrm{CH}\right)_{2}\right\} \mathrm{Cl}_{2}(\mathrm{py})_{3}$ (9)
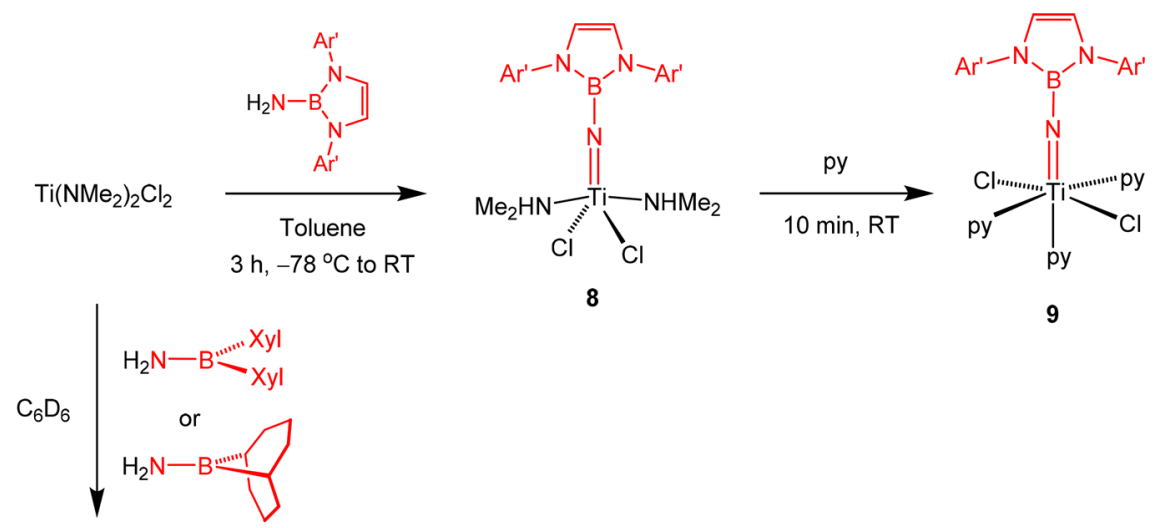

Unknown mixtures

complex $\operatorname{Ti}\left\{\mathrm{NB}\left(\mathrm{NAr}^{\prime} \mathrm{CH}\right)_{2}\right\} \mathrm{Cl}_{2}\left(\mathrm{NHMe}_{2}\right)_{2}$ (8) via double proton transfer (Scheme 1) from 6 to the $\mathrm{NMe}_{2}$ ligands. On the preparative scale in toluene, 8 was isolated in $79 \%$ yield. The ${ }^{1} \mathrm{H}$ NMR spectrum displays resonances for a $C_{s}$ symmetric species containing one $\mathrm{NB}\left(\mathrm{NAr}{ }^{\prime} \mathrm{CH}\right)_{2}$ and two $\mathrm{NHMe}_{2}$ ligands. The ${ }^{11} \mathrm{~B}$ chemical shift of the borylimido ligand in 8 is $14.2 \mathrm{ppm}$, upfield from the value of $23.0 \mathrm{ppm}$ for $\mathrm{H}_{2} \mathrm{NB}\left(\mathrm{NAr}{ }^{\prime} \mathrm{CH}\right)_{2}$ (6). DFT calculations on the full complex 8 gave a computed ${ }^{11} \mathrm{~B}$ NMR shift of $13.7 \mathrm{ppm}$, which is in good agreement with the experimental value.

Diffraction-quality crystals of $\mathbf{8}$ were grown from hexane. The solid state structure is shown in Figure 2, along with selected bond lengths and angles. Compound $\mathbf{8}$ has an approximately trigonal bipyramidal geometry $(\tau=0.19)$ in which the two $\mathrm{NHMe}_{2}$ ligands occupy the axial sites and the $\mathrm{Cl}$ and $\mathrm{NB}\left(\mathrm{NAr}^{\prime} \mathrm{CH}\right)_{2}$ ligands occupy equatorial ones. Compound 8 can be compared with a wide range of previously structurally

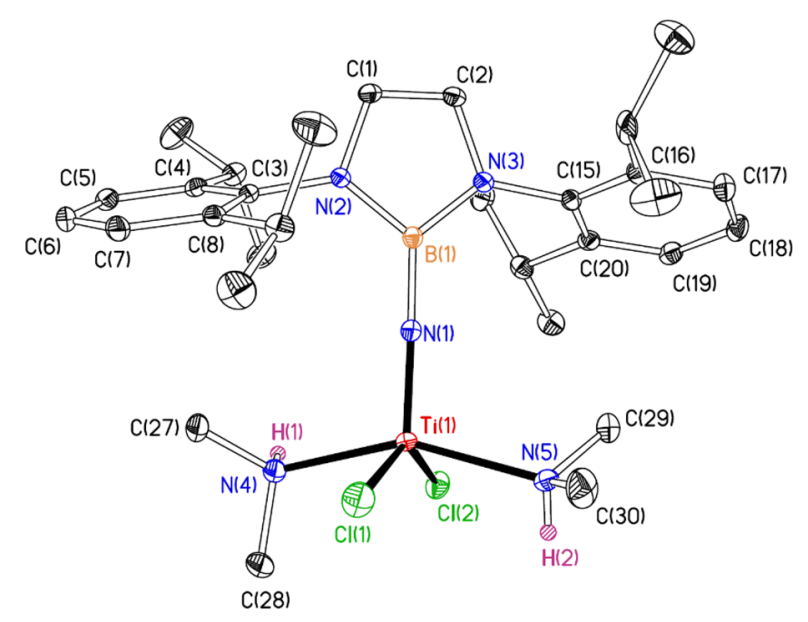

Figure 2. Displacement ellipsoid plot (25\% probability) of Ti\{NB$\left.\left(\mathrm{NAr}{ }^{\prime} \mathrm{CH}\right)_{2}\right\} \mathrm{Cl}_{2}\left(\mathrm{NHMe}_{2}\right)_{2}$ (8). C-bound $\mathrm{H}$ atoms are omitted for clarity. $\mathrm{H}(1)$ and $\mathrm{H}(2)$ are drawn as spheres of an arbitrary radius. Selected bond distances $(\AA)$ and angles $\left(^{\circ}\right)$ : $\mathrm{Ti}(1)-\mathrm{N}(1)$ 1.7027(10), $\mathrm{Ti}(1)-\mathrm{N}(4)$ 2.2235(11), $\mathrm{Ti}(1)-\mathrm{N}(5)$ 2.2447(11), $\mathrm{Ti}(1)-\mathrm{Cl}(1)$ 2.3224(4), $\mathrm{Ti}(1)-\mathrm{Cl}(2)$ 2.3730(4), N(1)-B(1) 1.4374(16), N(4)$\mathrm{H}(1) \quad 0.898(18), \quad \mathrm{N}(5)-\mathrm{H}(2) \quad 0.849(19), \mathrm{N}(1)-\mathrm{Ti}(1)-\mathrm{N}(4)$ 104.60(4), N(1)-Ti(1)-N(5) 102.30(4), N(4)-Ti(1)-N(5) 152.65(4), $\mathrm{N}(1)-\mathrm{Ti}(1)-\mathrm{Cl}(1) \quad 110.35(4), \quad \mathrm{N}(1)-\mathrm{Ti}(1)-\mathrm{Cl}(2)$ 108.21(4), $\mathrm{Cl}(1)-\mathrm{Ti}(1)-\mathrm{Cl}(2) \quad 141.288(17), \quad \mathrm{Ti}(1)-\mathrm{N}(1)-\mathrm{B}(1)$ $178.19(9) ; \tau=0.19^{21}$ characterized complexes $\mathrm{Ti}(\mathrm{NR}) \mathrm{Cl}_{2}\left(\mathrm{NHMe}_{2}\right)_{2}$ ( $\mathrm{R}=$ alkyl, aryl, $\left.\mathrm{O}^{t} \mathrm{Bu}\right)^{1,2,5-9}$ which have similar geometries. Of particular interest here is the $\operatorname{Ti}\left\{\mathrm{NB}\left(\mathrm{NAr}^{\prime} \mathrm{CH}\right)_{2}\right\}$ moiety. The short $\mathrm{Ti}(1)-\mathrm{N}(1)$ distance of $1.7027(10) \AA$ and the near-linear $\mathrm{Ti}(1)-\mathrm{N}(1)-\mathrm{B}(1)$ angle of $178.19(9)^{\circ}$, which implies sp hybridization at $\mathrm{N}(1)$, are both indicative of a $\mathrm{Ti} \equiv \mathrm{N}_{\mathrm{im}}$ triple bond ( $\sigma^{2} \pi^{4}$ configuration).

Previous structural ${ }^{19}$ and computational studies have found that $\mathrm{Ti}-\mathrm{N}_{\mathrm{im}}$ bond lengths typically follow the trend $\mathrm{Ti}-\mathrm{NR}$ ( $\mathrm{R}$ $=$ alkyl $)<\mathrm{Ti}-\mathrm{NO}^{t} \mathrm{Bu}<\mathrm{Ti}-\mathrm{NAr}<\mathrm{Ti}-\mathrm{NNR}_{2}^{\prime}\left(\mathrm{R}^{\prime}=\mathrm{Me}\right.$ or $\mathrm{Ph})$. The $\mathrm{Ti}(1)-\mathrm{N}(1)$ bond length of $1.7027(10) \AA$ in 8 places this value within the range reported for a series of eight arylimido complexes $\mathrm{Ti}(\mathrm{NAr}) \mathrm{Cl}_{2}\left(\mathrm{NHMe}_{2}\right)_{2}$ (av. $\mathrm{Ti}-\mathrm{N}_{\text {im }}=$ $1.703 \AA$, range $1.694(4)-1.708(2) \AA),{ }^{17 c, 20}$ whereas it is longer than in both the alkylimide $\mathrm{Ti}\left(\mathrm{N}^{\mathrm{i}} \mathrm{Pr}\right) \mathrm{Cl}_{2}\left(\mathrm{NHMe}_{2}\right)_{2}(1.672(2)$ $\AA)$ and the tert-butoxyimido analogue (av. 1.689(4) $\AA$ ). ${ }^{6 \mathrm{~b}, 17 \mathrm{c}}$ The $\mathrm{N}(1)-\mathrm{B}(1)$ distance of $1.4374(16) \AA$ is typical ${ }^{19}$ of compounds of the type $\mathrm{R}_{2} \mathrm{~N}-\mathrm{BR}_{2}{ }_{2}$ which have significant $\mathrm{N}=$ $\mathrm{B}$ double bond character via $\mathrm{N}_{2 \mathrm{p}} \rightarrow \mathrm{B}_{2 \mathrm{p}} \pi$-donation. More specifically, it is longer than in $\mathrm{Cp} * \mathrm{Ti}\left\{\mathrm{MeC}\left(\mathrm{N}^{\mathrm{i}} \mathrm{Pr}\right)_{2}\right\}$ $\left(\mathrm{NBC}_{8} \mathrm{H}_{14}\right)(2,1.402(4) \AA)^{4 \mathrm{q}}$ but comparable to Mindiola's $\mathrm{Ti}\left(\mathrm{NBEt}_{2}\right)\left(\mathrm{NTol}_{2}\right)\left\{\mathrm{HC}\left(\mathrm{C}^{\mathrm{t}} \mathrm{BuNAr}^{\prime}\right)_{2}\right\}(\mathbf{1}, 1.428(6) \AA) .{ }^{10}$ However, the differing ligand types and coordination numbers in these three compounds renders precise comparisons of $\mathrm{Ti}-\mathrm{N}_{\mathrm{im}}$ and $\mathrm{N}_{\mathrm{im}}-\mathrm{B}$ distances inappropriate.

In the solid state, $\mathbf{8}$ forms hydrogen-bonded dimers (see Figure $\mathrm{S} 1$ of the Supporting Information). Only $\mathrm{Cl}(2)$ and $\mathrm{N}(4) \mathrm{HMe}_{2}$ are involved in an $\mathrm{N}-\mathrm{H} \cdots \mathrm{Cl}$ hydrogen bond, the $\mathrm{H}(1) \cdots \mathrm{Cl}(2 \mathrm{~A})$ distance of $2.86(2) \AA$ A lying within the expected range for an "intermediate" strength $\mathrm{N}-\mathrm{H} \cdots \mathrm{Cl}$ hydrogen bond. ${ }^{22}$ This causes the longer $\mathrm{Ti}(1)-\mathrm{Cl}(2)$ distance of 2.3730(4) A compared to $\operatorname{Ti}(1)-\mathrm{Cl}(1)(2.3224(4) \AA)$. The solid state IR spectrum (Nujol mull) of $\mathbf{8}$ is consistent with this, showing two $\nu(\mathrm{N}-\mathrm{H})$ bands at 3289 and $3277 \mathrm{~cm}^{-1}$, assigned to the nonbridging $\mathrm{N}-\mathrm{H}$ bond and the hydrogen bonding $\mathrm{N}-$ $\mathrm{H}$, respectively. In dichloromethane solution, a single $\nu(\mathrm{N}-\mathrm{H})$ band is observed at $3288 \mathrm{~cm}^{-1}$. Hydrogen-bonded motifs (chains or dimers) have been reported for many compounds of the type $\mathrm{Ti}(\mathrm{NR}) \mathrm{Cl}_{2}\left(\mathrm{NHMe}_{2}\right)_{2}$. ${ }^{17 c, 20}$

Reactions were also carried out between $\mathrm{Ti}\left(\mathrm{NMe}_{2}\right)_{2} \mathrm{Cl}_{2}$ and $\mathrm{H}_{2} \mathrm{NBC}_{8} \mathrm{H}_{14}$ or $\mathrm{H}_{2} \mathrm{NBMes}_{2}$ (Scheme 1) in an attempt to make the corresponding diorganoborylimido complexes. The reaction of $\mathrm{H}_{2} \mathrm{NBMes}_{2}$ with $\mathrm{Ti}\left(\mathrm{NMe}_{2}\right)_{2} \mathrm{Cl}_{2}$ on the NMR tube scale in $\mathrm{C}_{6} \mathrm{D}_{6}$ at $50{ }^{\circ} \mathrm{C}$ (no reaction occurred at room temperature) formed a complex mixture of unknown products. Reaction with 
$\mathrm{H}_{2} \mathrm{NBC}_{8} \mathrm{H}_{14}$ also resulted in unknown products except for the known aminoborane ${ }^{23} \mathrm{Me}_{2} \mathrm{NBC}_{8} \mathrm{H}_{14}$ which could be identified from its ${ }^{1} \mathrm{H}$ and ${ }^{11} \mathrm{~B}$ NMR data. $\mathrm{Me}_{2} \mathrm{NBC}_{8} \mathrm{H}_{14}$ is possibly formed by an unproductive transamination reaction between a Ti-bound $\mathrm{NMe}_{2}$ ligand and the $\mathrm{NH}_{2}$ group of the borylamine, but the complex nature of the reaction product mixture precludes further speculation.

Given how little is known of these types of transamination reactions of borylamines with metal complexes, and the previously versatile nature of the amine-to-imide reactions of $\mathrm{Ti}\left(\mathrm{NMe}_{2}\right)_{2} \mathrm{Cl}_{2}$ with $\mathrm{H}_{2} \mathrm{NR}$, we examined selected model and full experimental systems by DFT at the B3PW91 level (see the Supporting Information for further details). The SCF energies for the model reactions of $\mathrm{Ti}\left(\mathrm{NMe}_{2}\right)_{2} \mathrm{Cl}_{2}$ with $\mathrm{H}_{2} \mathrm{NPh}$, $\mathrm{H}_{2} \mathrm{NMe}, \mathrm{H}_{2} \mathrm{NB}(\mathrm{NMeCH})_{2}, \mathrm{H}_{2} \mathrm{NBPh}_{2}$, and $\mathrm{H}_{2} \mathrm{NBMe}_{2}$ to form the corresponding imides $\mathrm{Ti}(\mathrm{NR}) \mathrm{Cl}_{2}\left(\mathrm{NHMe}_{2}\right)_{2}$ were $-15.2,-14.0,-14.9,-5.1$, and $-2.5 \mathrm{kcal} \mathrm{mol}^{-1}$, respectively. This shows a much reduced tendency on electronic grounds for this transformation in the case of the diorganoborylamines. Corresponding calculations (including corrections for dispersion and solvent effects (see the Supporting Information)) were also carried out on selected full experimental systems. The DFT reactions of $\mathrm{Ti}\left(\mathrm{NMe}_{2}\right)_{2} \mathrm{Cl}_{2}$ with $\mathrm{H}_{2} \mathrm{NPh}, \mathrm{H}_{2} \mathrm{~N}^{t} \mathrm{Bu}$, $\mathrm{H}_{2} \mathrm{NB}\left(\mathrm{NAr}^{\prime} \mathrm{CH}\right)_{2}$ (6), $\mathrm{H}_{2} \mathrm{NBMes}_{2}$, and monomeric $\mathrm{H}_{2} \mathrm{NBC}_{8} \mathrm{H}_{14}$ gave $\Delta_{\mathrm{r}} \mathrm{G}=-9.9,-7.8,-4.3,-2.0$, and +2.3

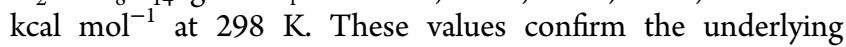
electronic trends, attenuated by the increased steric effects of the real substituents. The DFT results are consistent with the experimental outcomes ${ }^{17 \mathrm{c}}$ in the cases of $\mathrm{H}_{2} \mathrm{NPh}, \mathrm{H}_{2} \mathrm{~N}^{\mathrm{t}} \mathrm{Bu}$, and 6. In the case of $\mathrm{H}_{2} \mathrm{NBMes}_{2}$ the desired product is predicted to be thermodynamically viable, but the experimental observations show that alternative unknown and deleterious pathways are available (perhaps involving amine/amide group exchange as found with $\mathrm{H}_{2} \mathrm{NBC}_{8} \mathrm{H}_{14}$ ). In the case of $\mathrm{H}_{2} \mathrm{NBC}_{8} \mathrm{H}_{14}$ the target reaction is fairly endergonic, leading to alternative unknown pathways. We return to a detailed analysis of the factors controlling these types of exchange reaction later on.

Reaction of $\mathbf{8}$ with neat pyridine gave clean formation of $\operatorname{Ti}\left\{\mathrm{NB}\left(\mathrm{NAr}^{\prime} \mathrm{CH}\right)_{2}\right\} \mathrm{Cl}_{2}(\mathrm{py})_{3}(9)$ in $89 \%$ isolated yield (Scheme $1)$. We were also able to prepare compound 9 via a one-pot reaction from $\mathrm{Ti}\left(\mathrm{NMe}_{2}\right)_{2} \mathrm{Cl}_{2}$ without the need to purify the intermediate 8 , yielding $5.3 \mathrm{~g}$ of 9 from $1.5 \mathrm{~g}$ of $\mathrm{Ti}\left(\mathrm{NMe}_{2}\right)_{2} \mathrm{Cl}_{2}$ and $3.0 \mathrm{~g}$ of borylamine 6 (94\% overall yield). The ${ }^{1} \mathrm{H}$ NMR spectrum of 9 features the expected resonances for the borylimido ligand, as well as two sets of resonances in a 2:1 integration ratio for pyridine ligands cis and trans to the borylimido group. The signals for the trans-pyridine are significantly broadened, an effect which has also been described in the organoimido, hydrazido, and alkoxyimido complexes, ${ }^{6 b, 17 a, 18 a}$ and is attributed to a dissociative exchange of the more labile trans-pyridine ligands in solution. The ${ }^{11} \mathrm{~B}$ NMR shift of $13.8 \mathrm{ppm}$ is comparable to that of $14.2 \mathrm{ppm}$ in 8 .

Diffraction-quality crystals of 9 were grown from hexane at 5 ${ }^{\circ} \mathrm{C}$. The solid state structure is shown in Figure 3, along with selected bond lengths and angles. Compound 9 has an approximately octahedrally coordinated titanium, analogous to previous complexes of the type $\mathrm{Ti}(\mathrm{NR}) \mathrm{Cl}_{2}(\mathrm{py})_{3}$ ( $\mathrm{R}=$ alkyl, aryl, $\left.\mathrm{NPh}_{2}, \mathrm{O}^{\mathrm{t}} \mathrm{Bu}\right) .^{2 \mathrm{c}, 6 \mathrm{~b}, 8 \mathrm{a}, 17 \mathrm{a}, 20,24} \mathrm{Ti}(1)$ lies ca. $0.27 \AA$ above the $\{\mathrm{Cl}(1), \mathrm{Cl}(2), \mathrm{N}(5), \mathrm{N}(6)\}$ least-squares plane in order to enhance the $\operatorname{Ti}(1)-\mathrm{N}(1) \pi$-bonding, as described for certain imido and nitrido complexes. ${ }^{3 \mathrm{~d}, 25}$ The $\mathrm{Ti}(1)-\mathrm{N}(1)$ bond length of $1.7118(9) \AA$ is again indicative of a $\mathrm{Ti} \equiv \mathrm{N}_{\mathrm{im}}$ triple bond and falls within the range of $\mathrm{Ti}-\mathrm{N}_{\mathrm{im}}$ distances for

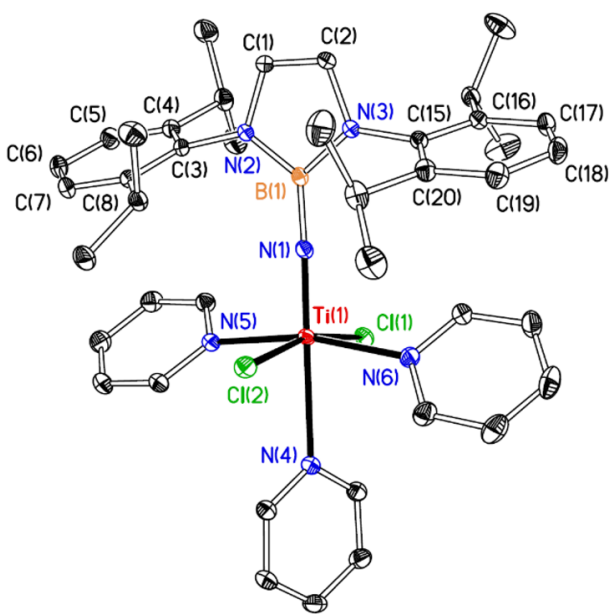

Figure 3. Displacement ellipsoid plot (30\% probability) of Ti\{NB$\left.\left(\mathrm{NAr}^{\prime} \mathrm{CH}\right)_{2}\right\} \mathrm{Cl}_{2}(\mathrm{py})_{3}(9) . \mathrm{H}$ atoms are omitted for clarity. Selected bond distances $(\AA)$ and angles $\left({ }^{\circ}\right): \operatorname{Ti}(1)-\mathrm{N}(1)$ 1.7118(9), $\mathrm{Ti}-\mathrm{N}(4)$ 2.5411(9), $\mathrm{Ti}(1)-\mathrm{N}(5)$ 2.2229(9), $\mathrm{Ti}(1)-\mathrm{N}(6)$ 2.2268(9), $\mathrm{Ti}(1)-$ $\mathrm{Cl}(1)$ 2.4106(3), $\mathrm{Ti}(1)-\mathrm{Cl}(2) 2.3861(3), \mathrm{N}(1)-\mathrm{B}(1)$ 1.4216(14), $\mathrm{N}(1)-\mathrm{Ti}(1)-\mathrm{N}(4)$ 179.37(3), $\mathrm{N}(1)-\mathrm{Ti}(1)-\mathrm{N}(5)$ 94.77(4), $\mathrm{N}(1)-$ $\mathrm{Ti}(1)-\mathrm{N}(6)$ 98.41(4), N(1)-Ti(1) $-\mathrm{Cl}(1)$ 96.30(3), N(1) $-\mathrm{Ti}(1)-$ $\mathrm{Cl}(2)$ 97.34(3), $\mathrm{Cl}(1)-\mathrm{Ti}(1)-\mathrm{Cl}(2)$ 166.343(12), $\mathrm{Ti}(1)-\mathrm{N}(1)-\mathrm{B}(1)$ $177.85(9)$.

structurally characterized arylimides $\mathrm{Ti}(\mathrm{NAr}) \mathrm{Cl}_{2}(\text { py })_{3}$ (av. Ti$\mathrm{N}_{\mathrm{im}}=1.718 \AA$, range $1.705(4)-1.730(2) \AA$ for six examples). ${ }^{17 a, 20,24 a, 26} \mathrm{Ti}(1)-\mathrm{N}(1)$ is longer than in both the alkylimide $\mathrm{Ti}\left(\mathrm{N}^{\mathrm{t}} \mathrm{Bu}\right) \mathrm{Cl}_{2}(\mathrm{py})_{3}(\mathbf{1 0} \text {, av. } 1.701(4) \AA)^{17 \mathrm{a}, 24 \mathrm{~b}}$ and in the alkoxyimide $\mathrm{Ti}\left(\mathrm{NO}^{\mathrm{t}} \mathrm{Bu}\right) \mathrm{Cl}_{2}(\mathrm{py})_{3}(\mathbf{1 1}, 1.7087(18) \AA)^{2},{ }^{2}$ and shorter than in the hydrazide $\mathrm{Ti}\left(\mathrm{NNPh}_{2}\right) \mathrm{Cl}_{2}(\mathrm{py})_{3}$ (12, $1.727(2) \AA) .{ }^{3}$ The $\mathrm{N}(1)-\mathrm{B}(1)$ bond length of $1.4216(14) \AA$ is comparable to that in $\mathbf{8}$.

The borylimido ligand exerts a strong trans influence (defined quantitatively as the difference between the $\mathrm{Ti}-\mathrm{N}$ bond lengths for the pyridine ligands cis and trans to the borylimido ligand) on the $\mathrm{N}(4)$ pyridine ligand. The average lengthening of $0.316(1) \AA$ is significantly larger than for the homologous $\mathrm{Ti}(\mathrm{NR}) \mathrm{Cl}_{2}(\mathrm{py})_{3}\left(\mathrm{R}={ }^{\mathrm{t}} \mathrm{Bu}(\mathbf{1 0}), \mathrm{Ph}, \mathrm{Tol}, \mathrm{P}(\mathrm{S}) \mathrm{Ph}_{2}\right.$; range $=0.18-0.21 \AA),{ }^{2 \mathrm{c}, 17 \mathrm{a}}$ hydrazides $\mathrm{Ti}\left(\mathrm{NNPh}_{2}\right) \mathrm{Cl}_{2}(\mathrm{~L})_{3}(\mathrm{~L}=$ py (12), 4- $\mathrm{NC}_{5} \mathrm{H}_{4}{ }^{\mathrm{t}} \mathrm{Bu}$; av. ca. $\left.0.16 \AA\right)^{3}$ and alkoxyimide 11 $(0.170(2) \AA) .{ }^{6 \mathrm{~b}}$ The trans influence in such complexes depends on a number of factors, including the $\mathrm{N}_{\mathrm{im}}$-substituent and the $\mathrm{Ti}-\mathrm{N}_{\mathrm{im}}$ bond distance. ${ }^{3 \mathrm{~d}, 17 \mathrm{a}}$ The large trans influence in the case of 9 may imply that the borylimido ligand has a very high $\sigma$-donor ability compared to its imido, hydrazido, and alkoxyimido analogues. This would be consistent with the well-developed chemistry of the $\mathrm{B}\left(\mathrm{NAr}^{\prime} \mathrm{CH}\right)_{2}$ moiety, which is itself a very strong $\sigma$-donor. ${ }^{9}$ Calculations for the [NB$\left.\left(\mathrm{NAr}{ }^{\prime} \mathrm{CH}\right)_{2}\right]^{2-}$ dianion $^{15}$ are consistent with this, and further DFT studies are described later in this contribution.

The borylimide 9 was specifically targeted because of its potential ability to act as a synthon for the installation of different supporting ligand sets. ${ }^{a, b, 8 a, 17 a}$ As a proof of principle, the dipyrrolide-amine ligand $\mathrm{N}_{2}{ }^{\text {pyr }} \mathrm{N}^{\mathrm{Me}}$ (the dianion of $\mathrm{N}, \mathrm{N}$ di(pyrrolyl- $\alpha$-methyl)- $N$-methylamine) was introduced via salt elimination. This ligand has previously been utilized by Odom in a number of imido and amido compounds relevant to small molecule activation and catalysis. ${ }^{4 \mathrm{~d}, \mathrm{f}, \mathrm{bb}, 27}$ Mixing 9 and $\mathrm{Li}_{2} \mathrm{~N}_{2}{ }^{\text {pyr }} \mathrm{N}^{\mathrm{Me}}$ in toluene at $-78{ }^{\circ} \mathrm{C}$, followed by warming to room temperature, and crystallization from $\mathrm{Et}_{2} \mathrm{O}$ afforded $\mathrm{Ti}\left(\mathrm{N}_{2}{ }^{\mathrm{pyr}} \mathrm{N}^{\mathrm{Me}}\right)\left\{\mathrm{NB}\left(\mathrm{NAr}{ }^{\prime} \mathrm{CH}\right)_{2}\right\}(\mathrm{py})_{2}(13$, eq 1) in $34 \%$ isolated 
<smiles>[3H][Te]([Al])(Cl)(Cl)=NB1N([Al])C=CN1[Ga]</smiles>

9

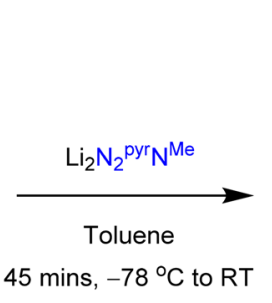

45 mins, $-78^{\circ} \mathrm{C}$ to $\mathrm{RT}$

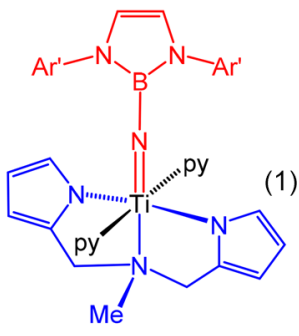

13 yield. The ${ }^{1} \mathrm{H}$ and ${ }^{13} \mathrm{C}$ NMR spectra of 13 indicate that the complex has $C_{s}$ symmetry in solution. One set of resonances for the chemically equivalent pyrrolyl groups are observed, whereas two are seen for the chemically inequivalent pyridine ligands (differentiated because of the orientation of the central $\mathrm{NMe}$ group of the tridentate ligand). The ${ }^{1} \mathrm{H}$ and ${ }^{13} \mathrm{C}$ resonances for the borylimido ligand are comparable to those in 8 and 9 and the ${ }^{11} \mathrm{~B}$ NMR shows a singlet at $13.2 \mathrm{ppm}$.

Diffraction-quality crystals of 13 were grown from $\mathrm{Et}_{2} \mathrm{O}$ at 5 ${ }^{\circ} \mathrm{C}$. The solid state structure is shown in Figure 4 along with

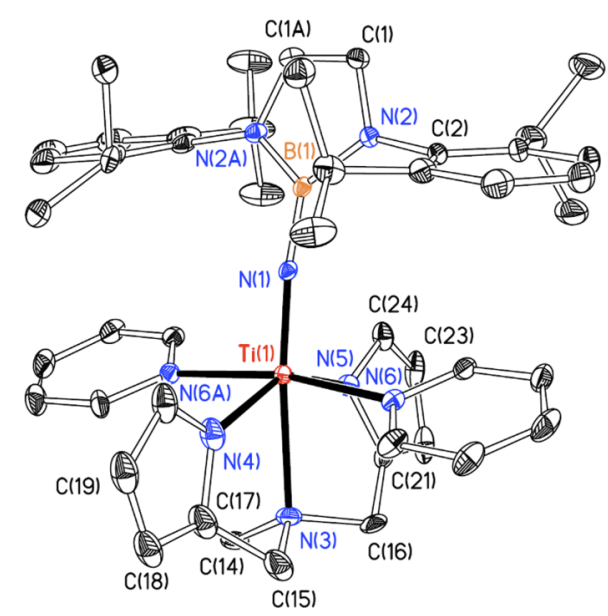

Figure 4. Displacement ellipsoid plot (20\% probability) of $\mathrm{Ti}$ $\left(\mathrm{N}_{2}{ }^{\mathrm{pyr}} \mathrm{N}^{\mathrm{Me}}\right)\left\{\mathrm{NB}\left(\mathrm{NAr}{ }^{\prime} \mathrm{CH}\right)_{2}\right\}(\mathrm{py})_{2}$ (13). $\mathrm{H}$ atoms are omitted for clarity. Atoms carrying the suffix ' $\mathrm{A}$ ' are related to their counterparts by the symmetry operator $[-x,-y, 1+z]$. Selected bond distances $(\AA)$ and angles $\left({ }^{\circ}\right)$ : $\mathrm{Ti}(1)-\mathrm{N}(1)$ 1.732(4), $\mathrm{Ti}(1)-\mathrm{N}(3)$ 2.440(5), $\mathrm{Ti}(1)-$ $\mathrm{N}(4)$ 2.064(6), $\mathrm{Ti}(1)-\mathrm{N}(5)$ 2.047(5), $\mathrm{Ti}(1)-\mathrm{N}(6) 2.258(3), \mathrm{N}(1)-$ $\mathrm{B}(1) \quad 1.421(8), \mathrm{N}(1)-\mathrm{Ti}(1)-\mathrm{N}(3) \quad 170.6(2), \mathrm{N}(1)-\mathrm{Ti}(1)-\mathrm{N}(4)$ 114.2(3), $\mathrm{N}(1)-\mathrm{Ti}(1)-\mathrm{N}(5)$ 98.0(2), $\mathrm{N}(1)-\mathrm{Ti}(1)-\mathrm{N}(6)$ 94.67(9), $\mathrm{N}(3)-\mathrm{Ti}(1)-\mathrm{N}(6)$ 85.99(9), $\mathrm{N}(4)-\mathrm{Ti}(1)-\mathrm{N}(5)$ 147.8(3), N(4)$\mathrm{Ti}(1)-\mathrm{N}(6)$ 84.76(9), N(5)-Ti(1)-N(6) 92.96(9), $\mathrm{Ti}(1)-\mathrm{N}(1)-$ B(1) 167.9(4).

selected bond lengths and angles. The tridentate ligand is coordinated in a meridional fashion as part of an overall distorted octahedral geometry, and the borylimido ligand is positioned trans to the central NMe donor. The $\mathrm{Ti}(1)-\mathrm{N}(1)$ bond length of 1.732(4) Å is again consistent with a triple bond but longer than that in $9(1.7118(9) \AA)$ due to the strongly donating anionic pyrrolide groups. The $\mathrm{N}(1)-\mathrm{B}(1)$ distance of $1.421(8) \AA$ is the same as that in 9 and seems relatively insensitive to the environment at the metal center. The structure also confirms that two pyridine ligands are retained from 9 and possess different environments due to the orientation of $\mathrm{C}(14)$.

Synthesis of Half-Sandwich Titanium Borylimides. As mentioned above, half-sandwich tert-butylimido, arylimido, hydrazido, and alkoxyimido complexes have shown a rich reaction chemistry of the $\mathrm{Ti}=\mathrm{NR}$ functional group. The latter three classes have usually been accessed through an imideamine exchange protocol in which a tert-butylimido ligand is displaced as $\mathrm{H}_{2} \mathrm{~N}^{t} \mathrm{Bu}$ by net protonolysis with the respective aniline, hydrazine, or alkoxyamine. ${ }^{3 \mathrm{~h}, 24 a, 28}$ The only previously reported half-sandwich borylimido compound of any transition metal is $\mathrm{Cp} * \mathrm{Ti}\left\{\mathrm{MeC}\left(\mathrm{N}^{\mathrm{i}} \mathrm{Pr}\right)_{2}\right\}\left(\mathrm{NBC}_{8} \mathrm{H}_{14}\right)$ (2) accessed by reductive $\mathrm{N}_{\mathrm{im}}-\mathrm{NR}_{2}$ bond cleavage of $\mathrm{Cp} * \mathrm{Ti}\left\{\mathrm{MeC}\left(\mathrm{N}^{\mathrm{i}} \mathrm{Pr}\right)_{2}\right\}$ $\left(\mathrm{NNR}_{2}\right)(\mathrm{R}=\mathrm{Me}$ or $\mathrm{Ph}$, vide supra $)$. This is not a general route since it works only for $9-\mathrm{BBN}^{4 \mathrm{q}}$ In addition it is difficult to separate 2 from the side-product aminoboranes $\mathrm{R}_{2} \mathrm{NBC}_{8} \mathrm{H}_{14}$ giving low overall yields. Thus, we aimed to extend the imideamine methodology to borylimido chemistry using $\mathrm{H}_{2} \mathrm{NB}$ $\left(\mathrm{NAr}^{\prime} \mathrm{CH}\right)_{2}$ (6) and corresponding diorganoborylamines $\mathrm{H}_{2} \mathrm{NBR}_{2}$.

When followed on the NMR tube scale in $\mathrm{C}_{6} \mathrm{D}_{6}$ solution at $90{ }^{\circ} \mathrm{C}$, reaction of $\mathrm{Cp}^{*} \mathrm{Ti}\left(\mathrm{N}^{\mathrm{t}} \mathrm{Bu}\right) \mathrm{Cl}(\mathrm{py})$ (14) with $\mathrm{H}_{2} \mathrm{NB}$ $\left(\mathrm{NAr}^{\prime} \mathrm{CH}\right)_{2}(6)$ resulted in slow and only partial (ca. 10\%) conversion to the target borylimido compound $\mathbf{1 5}$ at equilibrium. Higher temperatures and removal of the $\mathrm{H}_{2} \mathrm{~N}^{t} \mathrm{Bu}$ byproduct were required in order to drive the reaction to completion. This was achieved by performing the reaction in the melt, assisted by removal of $\mathrm{H}_{2} \mathrm{~N}^{\mathrm{t}} \mathrm{Bu}$ by a dynamic vacuum. Thus, heating of a mixture of 14 and 6 to $140{ }^{\circ} \mathrm{C}$ under a dynamic vacuum gave $\mathrm{Cp}{ }^{*} \mathrm{Ti}\left\{\mathrm{NB}\left(\mathrm{NAr}^{\prime} \mathrm{CH}\right)_{2}\right\} \mathrm{Cl}(\mathrm{py})(15)$ in $59 \%$ isolated yield (eq 2).

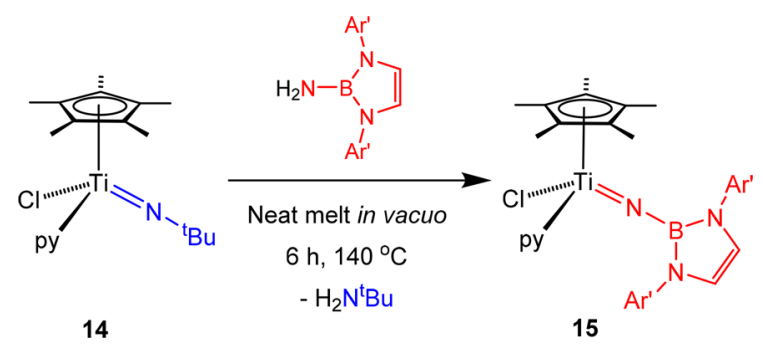

As an alternative route to $15, \operatorname{Ti}\left\{\mathrm{NB}\left(\mathrm{NAr}^{\prime} \mathrm{CH}\right)_{2}\right\} \mathrm{Cl}_{2}(\mathrm{py})_{3}$ (9) was reacted with 1 equiv of $\mathrm{LiCp}^{*}$ on the NMR tube scale. Heating for 3 days at $70{ }^{\circ} \mathrm{C}$ in $\mathrm{C}_{6} \mathrm{D}_{6}$ resulted in conversion of 9 to 15 . However, on scale-up, this route was accompanied by some decomposition side-reactions as judged by formation of $\mathrm{H}_{2} \mathrm{NB}\left(\mathrm{NAr}^{\prime} \mathrm{CH}\right)_{2}$, which is difficult to separate from $\mathbf{1 5}$ due to their similar solubilities Therefore, only the route via tertbutylimide/borylamine exchange was later used to reliably access 15. Attempts to prepare an unsubstituted cyclopentadienyl (i.e., $\eta-\mathrm{C}_{5} \mathrm{H}_{5}$ ) analogue of $\mathbf{1 5}$ from 9 and 1 equiv. $\mathrm{NaCp}$ also gave mixtures. This is discussed in further detail later on.

The ${ }^{1} \mathrm{H}$ and ${ }^{13} \mathrm{C}$ NMR spectra of $\mathbf{1 5}$ are consistent with the structure illustrated; a singlet was observed at $15.5 \mathrm{ppm}$ in the ${ }^{11} \mathrm{~B}$ NMR spectrum. Diffraction-quality crystals of 15 were grown from a benzene/hexane mixture at room temperature. The solid state structure is shown in Figure 5, along with selected bond distances and angles. The structures of six related complexes of the type $\mathrm{Cp}^{*} \mathrm{Ti}(\mathrm{NR}) \mathrm{Cl}(\mathrm{py})\left(\mathrm{R}={ }^{\mathrm{t}} \mathrm{Bu}(14), \mathrm{Ar}^{\prime}\right.$, 2,6- $\mathrm{C}_{6} \mathrm{H}_{3} \mathrm{Br}_{2}, 2-\mathrm{C}_{6} \mathrm{H}_{4}{ }^{\mathrm{t}} \mathrm{Bu}, 2-\mathrm{C}_{6} \mathrm{H}_{4}{ }^{\mathrm{i}} \mathrm{Pr}, \mathrm{NPh}_{2}$ ) have been reported to date, ${ }^{3 \mathrm{~h}, 24 a, 29}$ all of which are comparable to that of $\mathbf{1 5}$ with three-legged piano stool geometries. The $\mathrm{Ti}(1)-\mathrm{N}(1)$ bond distance of 1.7380(11) A for $\mathbf{1 5}$ falls within the range of values found for the arylimido analogues (range 1.7304(19)-1.753(2) 


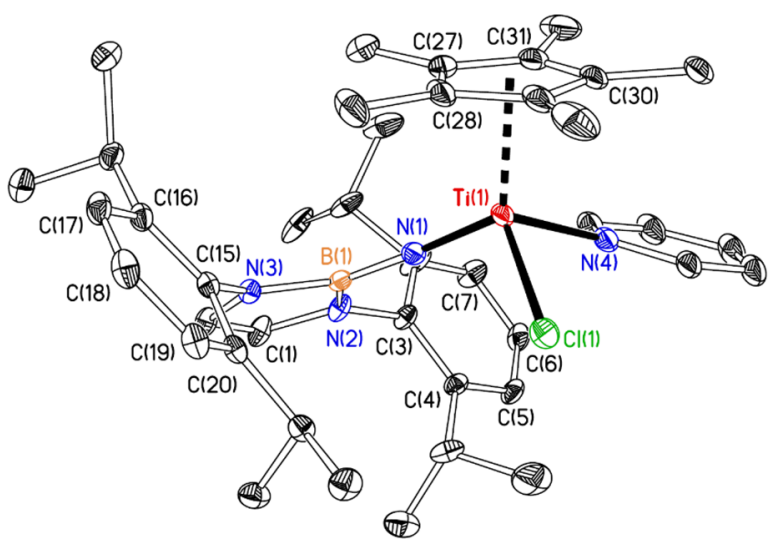

Figure 5. Displacement ellipsoid plot (20\% probability) of Cp*Ti$\left\{\mathrm{NB}\left(\mathrm{NAr}{ }^{\prime} \mathrm{CH}\right)_{2}\right\} \mathrm{Cl}(\mathrm{py})$ (15). $\mathrm{H}$ atoms are omitted for clarity. Selected bond distances $(\AA)$ and angles $\left({ }^{\circ}\right)$ : $\operatorname{Ti}(1)-\mathrm{N}(1)$ 1.7380(11), $\mathrm{Ti}(1)-\mathrm{N}(4)$ 2.1649(11), $\mathrm{Ti}(1)-\mathrm{Cl}(1)$ 2.3212(4), $\mathrm{Ti}(1)-\mathrm{Cp}_{\text {cent }}$ 2.07, $\mathrm{N}(1)-\mathrm{B}(1)$ 1.4153(17), $\mathrm{Cp}_{\text {cent }}-\mathrm{Ti}(1)-\mathrm{N}(1)$ 122.0, $\mathrm{Cp}_{\text {cent }}-\mathrm{Ti}(1)-\mathrm{N}(4)$ 110.1, $\mathrm{Cp}_{\text {cent }}-\mathrm{Ti}(1)-\mathrm{Cl}(1)$ 116.8, $\mathrm{N}(1)-\mathrm{Ti}(1)-\mathrm{Cl}(1) \quad 107.68(5), \mathrm{N}(4)-\mathrm{Ti}(1)-\mathrm{Cl}(1)$ 96.77(4), $\mathrm{N}(1)-\mathrm{Ti}(1)-\mathrm{N}(4)$ 99.16(5), $\mathrm{Ti}(1)-\mathrm{N}(1)-\mathrm{B}(1)$ 175.01(8). C $\mathrm{p}_{\text {cent }}$ refers to the centroid for the $\mathrm{C}_{5} \mathrm{Me}_{5}$ ring carbons.

$\AA)^{12}$ and is significantly longer than in the tert-butylimido homologue (av. 1.697(5) $\AA$ ). ${ }^{29}$

In an attempt to access organoborylimides, reactions of $\mathrm{Cp}^{*} \mathrm{Ti}\left(\mathrm{N}^{\mathrm{t}} \mathrm{Bu}\right) \mathrm{Cl}(\mathrm{py})$ (14) with $\mathrm{H}_{2} \mathrm{NBC}_{8} \mathrm{H}_{14}$ and $\mathrm{H}_{2} \mathrm{NBMes}_{2}$ were also explored. No success was found with either of these substrates, either in solution or melt conditions. At room temperature in $\mathrm{C}_{6} \mathrm{D}_{6}$, no reaction was observed with either amine, while the forcing conditions employed in higher temperature solution reactions, or in melts, ultimately resulted only in decomposition products. Further experiments and calculations probing this type of borylamine-tert-butylimide exchange reaction are discussed later.

The previously described $\mathrm{Cp} * \mathrm{Ti}\left\{\mathrm{MeC}\left(\mathrm{N}^{\mathrm{i}} \mathrm{Pr}\right)_{2}\right\}\left(\mathrm{NBC}_{8} \mathrm{H}_{14}\right)$ $(2)^{4 \mathrm{q}}$ is supported by a $\mathrm{Cp} * / \kappa^{2}-\mathrm{MeC}\left(\mathrm{N}^{\mathrm{i}} \mathrm{Pr}\right)_{2}$ ligand set which we have found useful as a ligand platform in related compounds. $^{4 \mathrm{r}, 6 \mathrm{~d}, 8 \mathrm{~b}, 30}$ Attempts to synthesize an analogous compound incorporating the $\mathrm{NB}\left(\mathrm{NAr}^{\prime} \mathrm{CH}\right)_{2}$ ligand by reaction of 15 with either $\mathrm{Li}\left[\mathrm{MeC}\left(\mathrm{N}^{i} \mathrm{Pr}\right)_{2}\right]$ or $\mathrm{Li}\left[\mathrm{PhC}\left(\mathrm{N}^{i} \mathrm{Pr}\right)_{2}\right]$ failed. This is probably due to significant steric constraints imposed by the large boryl ligand in this case. We therefore turned our attention to alternative monoanionic, $\kappa^{2}{ }_{\mathrm{N}, \mathrm{N}}$-bidentate ligands with reduced steric profiles. The first of these is the bicyclic guanidinate derived from $\mathrm{H}$-hpp (1,3,4,6,7,8-hexahydro- $\mathrm{H}$ pyrimido[1,2-a]pyrimidine), which has found some application in titanium organoimido chemistry previously. ${ }^{31}$ Second, the aminopyrrolide ligand $\mathrm{N}^{\mathrm{pyr}} \mathrm{N}^{\mathrm{Me}_{2}}\left(\mathrm{Me}_{2} \mathrm{NCH}_{2}\left(2-\mathrm{NC}_{4} \mathrm{H}_{3}\right)\right)$ was employed, which, along with related pyrrolide ligands, has been used extensively in Group 4 imido and hydrazido chemistry in recent years. ${ }^{4 \mathrm{~d}, \mathrm{e}, 27 \mathrm{a}, \mathrm{c}, 32}$

Reaction of 15 with 1 equiv of either $\mathrm{Li}[\mathrm{hpp}]$ or $\mathrm{LiN}^{\mathrm{pyr}} \mathrm{N}^{\mathrm{Me}_{2}}$ in toluene proceeded smoothly at $50{ }^{\circ} \mathrm{C}$ (Scheme 2). Following workup, $\mathrm{Cp}{ }^{*} \mathrm{Ti}(\mathrm{hpp})\left\{\mathrm{NB}\left(\mathrm{NAr}^{\prime} \mathrm{CH}\right)_{2}\right\} \quad(16)$ and $\mathrm{Cp}{ }^{*} \mathrm{Ti}-$ $\left(\mathrm{N}^{\mathrm{pyr}} \mathrm{N}^{\mathrm{Me}_{2}}\right)\left\{\mathrm{NB}\left(\mathrm{NAr}{ }^{\prime} \mathrm{CH}\right)_{2}\right\}$ (17) were isolated in 68 and $71 \%$ yield, respectively. The ${ }^{1} \mathrm{H}$ and ${ }^{13} \mathrm{C}$ NMR spectra of 16 are indicative of a $C_{s}$ symmetric species. Those of 17 suggest a $C_{1}$ symmetric species. The ${ }^{11} \mathrm{~B}$ NMR spectra showed single resonances at 14.6 (DFT calculated 14.0) and $15.3 \mathrm{ppm}$, respectively. Diffraction-quality crystals of 16 and 17 were grown from hexane. The solid state structure of $\mathbf{1 6}$ is shown in Figure 6, along with selected bond distances and angles, and that of $\mathbf{1 7}$ is shown in Figure S2 of the Supporting Information.

Both 16 and 17 possess three-legged piano stool geometries, with an $\eta^{5}-\mathrm{C}_{5} \mathrm{Me}_{5}$ ligand, $\eta^{1}$-borylimido ligand and a $\kappa^{2}-\mathrm{N}, \mathrm{N}^{\prime}-$ hpp or $-\mathrm{N}^{\mathrm{pyr}} \mathrm{N}^{\mathrm{Me}_{2}}$. Comparison of the metric parameters of the $\mathrm{Ti}-\mathrm{N}_{\mathrm{im}}-\mathrm{B}$ linkages show that the borylimido moiety is broadly similar in the two compounds. The $\mathrm{Ti}(1)-\mathrm{N}(1)(1.7433(19)$ and $1.7444(12) \AA$ in 16 and 17 respectively) and $\mathrm{N}(1)-\mathrm{B}(1)$ distances (1.422(3) and 1.4318(19) $\AA$ ), along with the $\mathrm{Ti}(1)-$ $\mathrm{N}(1)-\mathrm{B}(1)$ angles $\left(176.00(17)\right.$ and $\left.174.15(10)^{\circ}\right)$ are all in agreement with the structural data discussed above.

Scheme 2. Synthesis of $\mathrm{Cp}^{*} \mathrm{Ti}(\mathrm{hpp})\left\{\mathrm{NB}\left(\mathrm{NAr}{ }^{\prime} \mathrm{CH}\right)_{2}\right\}(16)$ and $\mathrm{Cp} * \mathrm{Ti}\left(\mathrm{N}^{\mathrm{pyr}^{2}} \mathrm{~N}^{\mathrm{Me}_{2}}\right)\left\{\mathrm{NB}\left(\mathrm{NAr}{ }^{\prime} \mathrm{CH}\right)_{2}\right\}$ (17), from $\mathrm{Cp}^{*} \mathrm{Ti}\left\{\mathrm{NB}\left(\mathrm{NAr}^{\prime} \mathrm{CH}\right)_{2}\right\} \mathrm{Cl}(\mathbf{p y})(15)$
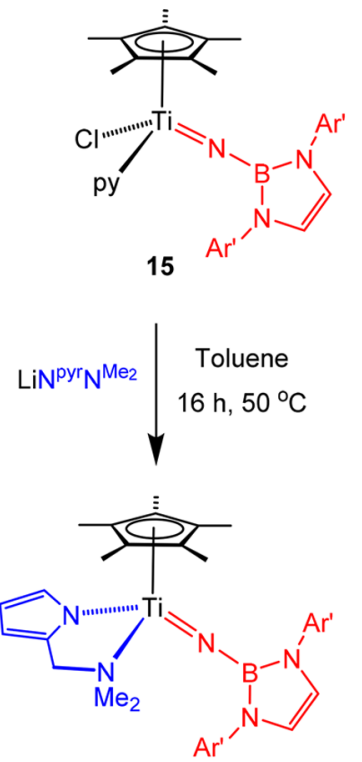

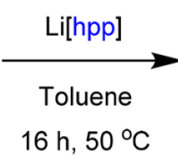

$16 \mathrm{~h}, 50^{\circ} \mathrm{C}$

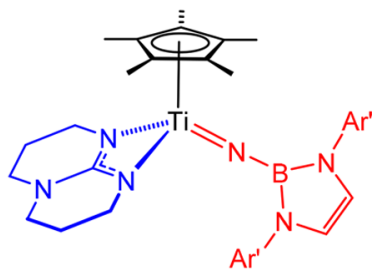

16 


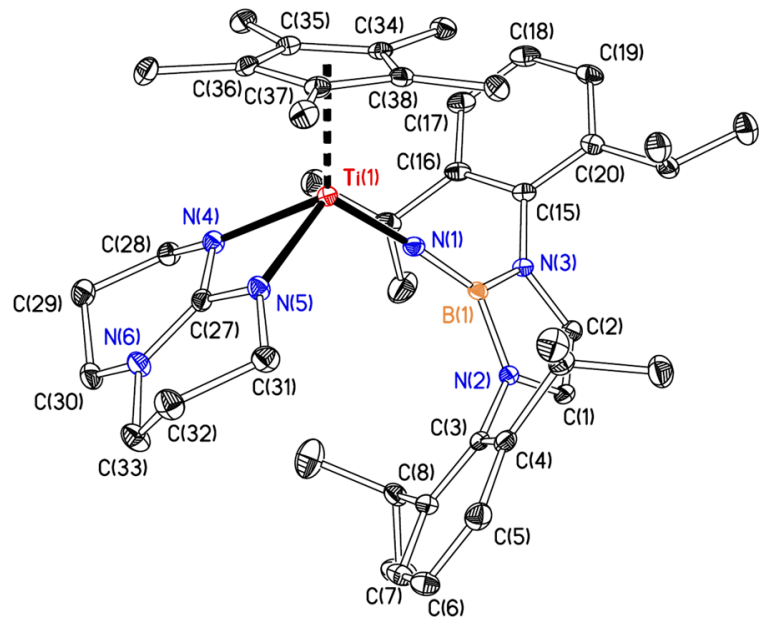

Figure 6. Displacement ellipsoid plot (20\% probability) of $\mathrm{Cp}^{*} \mathrm{Ti}-$ (hpp) $\left\{\mathrm{NB}\left(\mathrm{NAr}{ }^{\prime} \mathrm{CH}\right)_{2}\right\}(\mathbf{1 6}) . \mathrm{H}$ atoms are omitted for clarity. Selected bond distances $(\AA)$ and angles (deg): $\mathrm{Ti}(1)-\mathrm{N}(1)$ 1.7433(19), $\mathrm{Ti}(1)-\mathrm{N}(4)$ 2.0790(18), $\mathrm{Ti}(1)-\mathrm{N}(5) 2.0753(19), \mathrm{Ti}(1)-\mathrm{Cp}_{\text {cent }} 2.07$, $\mathrm{N}(1)-\mathrm{B}(1) 1.422(3), \mathrm{N}(1)-\mathrm{Ti}(1)-\mathrm{Cp}_{\text {cent }} 125.1, \mathrm{~N}(4)-\mathrm{Ti}(1)-\mathrm{Cp}_{\text {cent }}$ 117.1, $\mathrm{N}(5)-\mathrm{Ti}(1)-\mathrm{Cp}_{\text {cent }}$ 115.0, $\mathrm{N}(1)-\mathrm{Ti}(1)-\mathrm{N}(4) \quad 109.87(8)$, $\mathrm{N}(1)-\mathrm{Ti}(1)-\mathrm{N}(5)$ 109.56(8) $\mathrm{N}(4)-\mathrm{Ti}(1)-\mathrm{N}(5)$ 64.95(7), $\mathrm{Ti}(1)-$ $\mathrm{N}(1)-\mathrm{B}(1) 176.00(17) . \mathrm{Cp}_{\text {cent }}$ refers to the centroid for the $\mathrm{C}_{5} \mathrm{Me}_{5}$ ring carbons.

Compound 16 allows for a fairer comparison (in terms of structural similarity) between its $\mathrm{Ti}-\mathrm{NB}\left(\mathrm{NAr}^{\prime} \mathrm{CH}\right)_{2}$ group and the corresponding $\mathrm{Ti}-\mathrm{NBC}_{8} \mathrm{H}_{14}$ in $\mathrm{Cp} * \mathrm{Ti}\left\{\mathrm{MeC}\left(\mathrm{N}^{\mathrm{i}} \mathrm{Pr}\right)_{2}\right\}$ $\left(\mathrm{NBC}_{8} \mathrm{H}_{14}\right)\left(2, \mathrm{Ti}-\mathrm{N}_{\mathrm{im}}=1.731(3) \AA\right) .{ }^{4 \mathrm{q}}$ Interestingly, the $\mathrm{Ti}-\mathrm{N}_{\mathrm{im}}$ distances are equivalent (difference $=0.012(4) \AA$ ) at the $3 \sigma$ level of uncertainty, but quite possibly are still influenced by the different steric requirements in each system. The $\mathrm{N}(1)-$ $\mathrm{B}(1)$ distances are also similar (1.422(3) (16) and 1.402(4) $\AA$ ), but the difference of 0.020 (5) $\AA$ is significant at the $3 \sigma$ level of uncertainty. This suggests more multiple $(\pi)$ bond character in the $\mathrm{N}_{\mathrm{im}}-\mathrm{B}$ bond of 2 , as would be expected since the $\mathrm{NBC}_{8} \mathrm{H}_{14}$ ligand does not have additional $\mathrm{N}$ atom (lone pair) donors adjacent to the boron to compete for the vacant $2 p$ atomic orbital. To probe this further we determined the X-ray structure of $\mathrm{H}_{2} \mathrm{NB}\left(\mathrm{NAr}^{\prime} \mathrm{CH}\right)_{2}$ (see Figure $\mathrm{S} 3$ in the Supporting Information) and found a $\mathrm{B}-\mathrm{NH}_{2}$ distance of 1.41(1) (computed value $1.417 \AA$ ). The amine " $\mathrm{H}_{2} \mathrm{NBC}_{8} \mathrm{H}_{14}$ " in fact exists as a $\mathrm{B}\left(\mu-\mathrm{NH}_{2}\right) \mathrm{B}$ bridged dimer in the solid state, ${ }^{33}$ so an experimental comparison of the $\mathrm{B}-\mathrm{NH}_{2}$ distance in the monomer cannot be made. The DFT computed value was $1.395 \AA, 0.022 \AA$ shorter than in the computed version of $\mathrm{H}_{2} \mathrm{NB}\left(\mathrm{NAr}{ }^{\prime} \mathrm{CH}\right)_{2}$. This difference is comparable to that between the $\mathrm{N}(1)-\mathrm{B}(1)$ distances in 16 and 2. Further comparisons are made using DFT later.

Isodesmic Borylimide-Amine Exchange Reactions. $\mathrm{Cp}{ }^{*} \mathrm{Ti}(\mathrm{hpp})\left(\mathrm{N}^{\mathrm{t}} \mathrm{Bu}\right)(\mathbf{1 8})$, the tert-butylimido analogue of $\mathbf{1 6}$, was prepared from 14 and $\mathrm{Li}[\mathrm{hpp}]$. Given access to both 16 and 18 independently of each other, these and related hppsupported compounds were used to develop comparative isodesmic amine-borylimide exchange reactions so as to probe further the bond energetics in these systems (Scheme 3).

The 1:1 reaction of 16 with $\mathrm{H}_{2} \mathrm{~N}^{t} \mathrm{Bu}$ in $\mathrm{C}_{6} \mathrm{D}_{6}$ at room temperature immediately formed an equilibrium mixture with 18 and the borylamine 6 (ratio of $[18]:[16]=70: 30 ; K_{\mathrm{eq}}=$ 5.44 ) giving an experimental $\Delta_{\mathrm{r}} G=-1.0 \mathrm{kcal} \mathrm{mol}^{-1}$ at $298 \mathrm{~K}$ for the reaction $16+\mathrm{H}_{2} \mathrm{~N}^{t} \mathrm{Bu} \rightarrow \mathbf{1 8}+\mathrm{H}_{2} \mathrm{NB}\left(\mathrm{NAr}^{\prime} \mathrm{CH}\right)_{2}$. The same equilibrium mixture was formed from the 1:1 reaction of 18 and 6. DFT calculations gave $\Delta_{\mathrm{r}} G=0.6 \mathrm{kcal} \mathrm{mol}^{-1}$, consistent with a fine-balanced equilibrium.

Reaction of 16 with 1 equiv of $\mathrm{H}_{2} \mathrm{NTol}$ gave $50 \%$ conversion to the bis(anilido) compound $\mathrm{Cp}^{*} \mathrm{Ti}(\mathrm{hpp})(\mathrm{NHTol})_{2}(19)$ as opposed to the expected terminal imide Cp*Ti(hpp)(NTol), presumably due to the reduced steric profile of hpp (Scheme 3 ). Reaction with 2 equiv of $\mathrm{H}_{2} \mathrm{NTol}$ quantitatively formed 19. As a fairer comparison (since formation of 19 is not an isodesmic reaction), the reaction of 16 with 1 equiv of $\mathrm{H}_{2} \mathrm{NXyl}$ $\left(\mathrm{Xyl}=2,6-\mathrm{C}_{6} \mathrm{H}_{3} \mathrm{Me}_{2}\right)$ in $\mathrm{C}_{6} \mathrm{D}_{6}$ was performed, and this gave quantitative conversion to the terminal imide $\mathrm{Cp}{ }^{*} \mathrm{Ti}(\mathrm{hpp})$ (NXyl) (20) and borylamine 6. The DFT-computed $\Delta_{\mathrm{r}} G$ for this reaction is $-6.1 \mathrm{kcal} \mathrm{mol}^{-1}$, in agreement with experiment. Compounds 19 and 20 were conveniently prepared and fully characterized on scale-up by imide-amine exchange from $C p^{*} \operatorname{Ti}(h p p)\left(N^{t} B u\right)(18)$ and the respective aniline. The $\mathrm{X}$ -

Scheme 3. Borylimido Ligand Exchange Reactions of $\mathrm{Cp}^{*} \mathrm{Ti}(\mathrm{hpp})\left\{\mathrm{NB}\left(\mathrm{NAr} \mathbf{C H}_{2}\right\}\right.$ (16) with $\mathrm{H}_{2} \mathrm{~N}^{\mathrm{t} B u}, \mathrm{H}_{2} \mathrm{NXyl}$, and $\mathrm{H}_{2} \mathrm{NTol}$

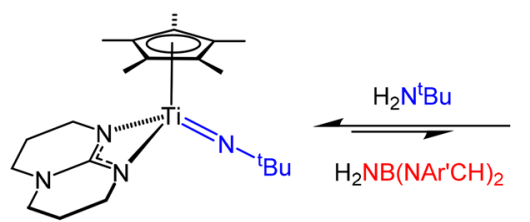

18

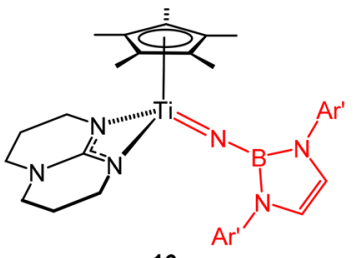

16

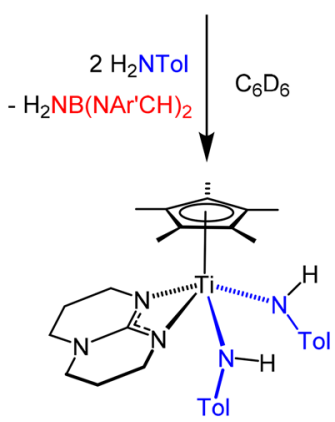

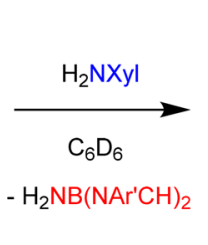

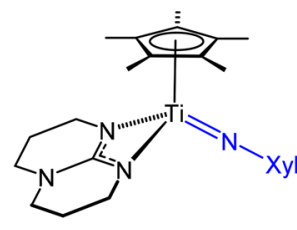

20 
ray structures of $\mathbf{1 8}$ and $\mathbf{1 9}$ are given in Figure S4 of the Supporting Information.

No reaction was observed at room temperature or with heating between $\mathrm{Cp} \mathrm{p}^{*} \mathrm{Ti}(\mathrm{hpp})\left(\mathrm{N}^{\mathrm{t} B u}\right)$ (18) and either $\mathrm{H}_{2} \mathrm{NBMes}_{2}$ or $\mathrm{H}_{2} \mathrm{NBC}_{8} \mathrm{H}_{14}$, consistent with the failure of other attempts (vide supra) at tert-butylimide-amine reactions with these diorganoborylamines. The DFT-computed $\Delta_{\mathrm{r}} G$ for the reaction of 18 with $\mathrm{H}_{2} \mathrm{NBC}_{8} \mathrm{H}_{14}$ was $+10.6 \mathrm{kcal} \mathrm{mol}^{-1}$ $\left(+12.8 \mathrm{kcal} \mathrm{mol}^{-1}\right.$ taking into account initial dissociation of the aminoborane dimer), consistent with experiment. Likewise, $\mathrm{Cp}{ }^{*} \mathrm{Ti}(\mathrm{hpp})\left\{\mathrm{NB}\left(\mathrm{NAr}{ }^{\prime} \mathrm{CH}\right)_{2}\right\}(\mathbf{1 6})$ did not react with either of these aminoboranes.

Since the closely related $\mathrm{Cp}{ }^{*} \mathrm{Ti}\left\{\mathrm{MeC}\left(\mathrm{N}^{\mathrm{i}} \mathrm{Pr}\right)_{2}\right\}\left(\mathrm{NBC}_{8} \mathrm{H}_{14}\right)$ (2) can be prepared without requiring imide-amine or other exchange protocols, it provides an experimental way to probe the energetics of dialkylborylamine-tert-butylimide exchange from the opposite direction (eq 3). As expected, reaction of 2

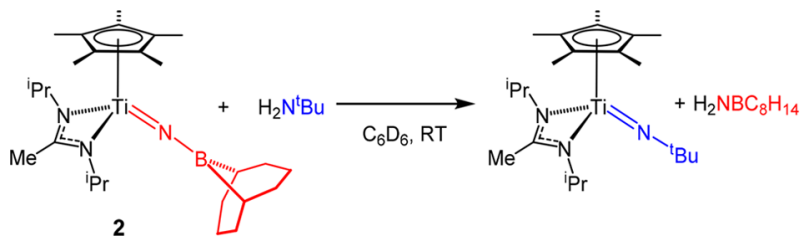

with 1 equiv of $\mathrm{H}_{2} \mathrm{~N}^{\mathrm{t}} \mathrm{Bu}$ in $\mathrm{C}_{6} \mathrm{D}_{6}$ quantitatively formed the known ${ }^{28} \mathrm{Cp} * \mathrm{Ti}\left\{\mathrm{MeC}\left(\mathrm{N}^{\mathrm{i}} \mathrm{Pr}\right)_{2}\right\}\left(\mathrm{N}^{\mathrm{t}} \mathrm{Bu}\right)$ and $\mathrm{H}_{2} \mathrm{NBC}_{8} \mathrm{H}_{14}$. The DFT-computed $\Delta_{\mathrm{r}} G$ for this reaction is $-8.2 \mathrm{kcal} \mathrm{mol}^{-1}(-6.0$ $\mathrm{kcal} \mathrm{mol}{ }^{-1}$ without taking into account dimerization of the aminoborane) at $298 \mathrm{~K}$. Analogous experimental outcomes were found with $\mathrm{H}_{2} \mathrm{NTol}$ and $\mathrm{H}_{2} \mathrm{NNPh}_{2}$ forming Cp*Ti$\left\{\mathrm{MeC}\left(\mathrm{N}^{\mathrm{i} P r}\right)_{2}\right\}(\mathrm{NR})\left(\mathrm{R}=\right.$ Tol or $\left.\left.\mathrm{NPh}_{2}\right)\right)^{8 \mathrm{~b}, 28,30}$

DFT and QTAIM Study of the Bonding and Borylimide-Amine Exchange Energetics of Cyclopentadienyl-Amidinate Complexes. Two previous studies have examined aspects of the bonding in transition metal borylimides, namely, Bettinger's analysis ${ }^{16 \mathrm{c}}$ of the hypothetical 20 valence electron $(\mathrm{CO})_{4} \mathrm{Fe}(\mathrm{NBCat})$ and $(\mathrm{CO})_{4} \mathrm{Fe}\left(\mathrm{NBH}_{2}\right)$, and ours for the transient borylimide $\left(\mathrm{NacNac}^{\mathrm{NMe}_{2}}\right) \mathrm{Sc}\{\mathrm{NB}$ $\left.\left(\mathrm{NAr}^{\prime} \mathrm{CH}\right)_{2}\right\} \quad\left(7\right.$, Figure 1). ${ }^{15}$ We compared scandiumborylimide and scandium-arylimide bonding, concluding that heteroatom-substituted borylimido ligands of the type NB-
$\left(\mathrm{NAr}^{\prime} \mathrm{CH}\right)_{2}$ are better $\sigma$ - and $\pi$-donors than their arylimido counterparts and form stronger $\mathrm{Sc}-\mathrm{N}_{\mathrm{im}}$ bonds. We also accounted for differences observed in the reactions of scandium boryl- and aryl-imido compounds with saturated and unsaturated substrates, concluding that substrate 1,2-addition to the $\mathrm{Sc}-\mathrm{N}_{\text {im }}$ bond of $\left(\mathrm{NacNac}^{\mathrm{NMe}_{2}}\right) \mathrm{Sc}\left(\mathrm{NB}\left(\mathrm{NAr}{ }^{\prime} \mathrm{CH}\right)_{2}\right\}$ is energetically more favorable than the same reaction for $\left(\mathrm{NacNac}^{\mathrm{NMe}_{2}}\right) \mathrm{Sc}\left(\mathrm{NAr}^{\prime}\right)$. However, these previous studies were necessarily somewhat limited in scope: (i) there are relatively few types of rare earth-imido compounds to compare with, and so a broader contextual view of metal-borylimido bonding could not be developed; (ii) no scandium borylimide has been structurally characterized which prevents the testing of structure-bonding predictions; (iii) no experimental data are available for borylimido compounds (L)Sc(NBR $)_{2}$ without heteroatom donor R-groups. We therefore set out to develop a more detailed and integrated picture of the bonding and thermodynamic features of the different types of borylimides represented by $\mathrm{Cp} * \mathrm{Ti}\left\{\mathrm{MeC}\left(\mathrm{N}^{\mathrm{i}} \mathrm{Pr}\right)_{2}\right\}\left(\mathrm{NBC}_{8} \mathrm{H}_{14}\right) \quad$ (2) and $\mathrm{Cp}{ }^{*} \mathrm{Ti}(\mathrm{hpp})\left\{\mathrm{NB}\left(\mathrm{NAr}^{\prime} \mathrm{CH}\right)_{2}\right\}$ (16). We decided to approach this (vide infra) by comparing them with the previously reported alkyl- and aryl-imido, and hydrazido homologues $\mathrm{Cp}^{*} \mathrm{Ti}\left\{\mathrm{MeC}\left(\mathrm{N}^{\mathrm{i} P r}\right)_{2}\right\}(\mathrm{NR})\left(\mathrm{R}={ }^{\mathrm{t}} \mathrm{Bu}\right.$, aryl, $\left.\mathrm{NNR}_{2}^{\prime}\right)$. These have complementary imido $\mathrm{N}$-substituents (no $\pi$-effects for $\mathrm{R}=$ alkyl; $\pi$-donor for $\mathrm{R}=\mathrm{NR}_{2}^{\prime}$; tunable $\pi$-acceptor for $\mathrm{R}^{\prime}=4$ $\mathrm{C}_{6} \mathrm{H}_{4} \mathrm{X}$ as a function of the para $\mathrm{X}$-group).

The DFT complexes used in this study are shown in Figure 7. $\mathbf{1 Q} \mathbf{B M e}_{2}$ is a model for $\mathrm{Cp} * \mathrm{Ti}\left\{\mathrm{MeC}\left(\mathrm{N}^{\mathrm{i} P r}\right)_{2}\right\}\left(\mathrm{NBC}_{8} \mathrm{H}_{14}\right)$ (2), and $1 \mathrm{Q} \mathbf{B}(\mathrm{NMeCH})_{2}$ represents $\mathrm{Cp} * \mathrm{Ti}(\mathrm{hpp})\{\mathrm{NB}-$ $\left.\left(\mathrm{NAr}{ }^{\prime} \mathrm{CH}\right)_{2}\right\}$ (16). Although the real compound has a $\kappa^{2}$ guanidinate ligand in place of $\kappa^{2}$-amidinate, DFT control calculations on the hpp-supported systems $\mathrm{CpTi}(\mathrm{hpp})(\mathrm{NR})(\mathrm{R}$ $\left.=\mathrm{Me}, \mathrm{Ph}, \mathrm{B}(\mathrm{NMeCH})_{2}, \mathrm{BMe}_{2}\right)$ showed that their bond dissociation energies and imide-amine exchange energies are very similar to, and scale with, those of their $\mathrm{CpTi}\{\mathrm{MeC}$ $\left.(\mathrm{NMe})_{2}\right\}(\mathrm{NR})$ counterparts (Figure S5 of the Supporting Information).

As mentioned, the $\mathrm{Ti}-\mathrm{N}_{\mathrm{im}}$ bonding in alkyl, aryl and hydrazido systems $\mathrm{CpTi}\left\{\mathrm{MeC}(\mathrm{NMe})_{2}\right\}(\mathrm{NR})$ ( $\mathrm{R}=\mathrm{Me}$, aryl, $\mathrm{NR}_{2}$ ) has been studied previously using molecular orbital and NBO analysis approaches. ${ }^{8 b}$ In each case, $\mathrm{Ti}-\mathrm{N}_{\mathrm{im}}$ is described as a triple bond $\left(\sigma^{2} \pi^{4}\right.$ configuration). As a point of reference

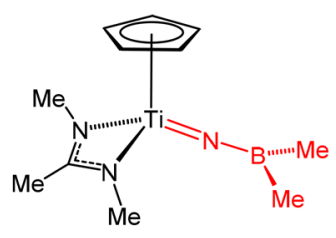

$R=M e\left(1 Q \_B M e_{2}\right)$

or $\mathrm{Ph}\left(1 \mathrm{Q} \_\mathrm{BPh}_{2}\right)$

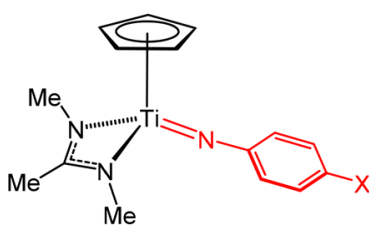

$X=H\left(1 Q_{-} P h\right)$

$\mathrm{CF}_{3}\left(1 \mathrm{Q} \_4-\mathrm{C}_{6} \mathrm{H}_{4} \mathrm{CF}_{3}\right)$

or $\mathrm{NH}_{2}\left(1 \mathrm{Q}_{-} 4-\mathrm{C}_{6} \mathrm{H}_{4} \mathrm{NH}_{2}\right)$
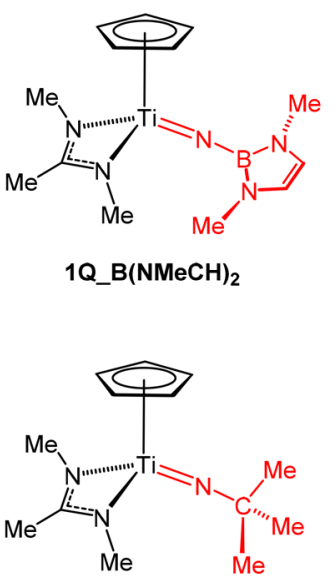

$1 Q_{-}{ }^{\mathrm{B}} \mathrm{Bu}$

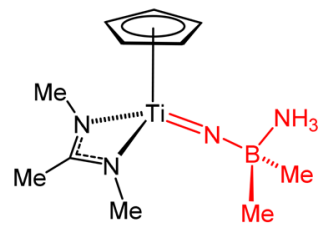

1Q_BMe ${ }_{2} \mathrm{NH}_{3}$<smiles>CC1=NN(C)[Te](=NN(C)C)(c2ccccc2)C1</smiles><smiles>CC1=C(C)N(C)[Al](=NN(C)C)N1C</smiles>

1Q_NMe 2_pyram

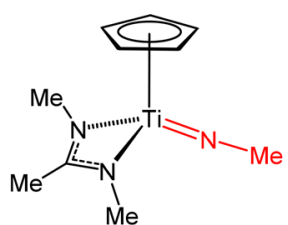

1Q_Me

1Q_NMe 2_planar

Figure 7. Model cyclopentadienyl-amidinate complexes. 
the two Ti- $\mathrm{N}_{\mathrm{im}} \pi$-bonding MOs (denoted $\pi_{\mathrm{v}}$ (lying in the approximate molecular mirror plane) and $\pi_{\mathrm{h}}$ ) of $1 \mathrm{Q}$ Me are shown in Figure 8 . The $\mathrm{Ti}(3 \mathrm{~d})-\mathrm{N}(2 \mathrm{p})$ component of $\pi_{\mathrm{h}}$ of
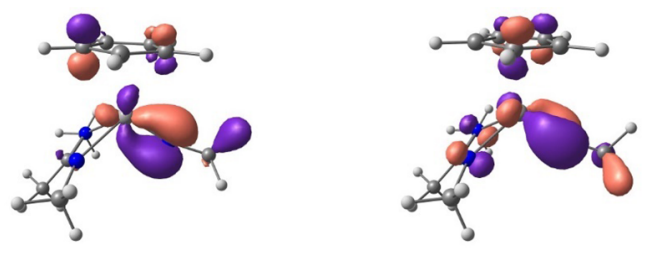

HOMO-1 $\left(\pi_{\mathrm{v}},-5.68 \mathrm{eV}\right)$

HOMO-2 $\left(\pi_{\mathrm{h}},-6.17 \mathrm{eV}\right)$

Figure 8. DFT computed $\mathrm{Ti}-\mathrm{N}_{\mathrm{im}} \pi$-type molecular orbitals of $\mathrm{CpTi}\left\{\mathrm{MeC}(\mathrm{NMe})_{2}\right\}(\mathrm{NMe})(\mathbf{1 Q} \mathbf{M e})$. Isosurfaces are drawn at the 0.036 au contour level.

1Q $\mathbf{R}$ does not interact with $\mathrm{R}$-substituent $\pi$-type orbitals as they are oriented orthogonal to it, whereas in $\pi_{\mathrm{v}}$ it interacts quite strongly. When $\mathrm{R}=$ phenyl the ring acts as a net $\pi$ acceptor from $\pi_{\mathrm{v}}$, and where $\mathrm{R}=\mathrm{NR}_{2}^{\prime}$ it acts as a $\pi$-donor to the $\mathrm{Ti}-\mathrm{N}_{\mathrm{im}}$ antibonding $\mathrm{MO}, \pi^{*}{ }_{v}$, especially when the $\mathrm{NR}_{2}{ }_{2}$ nitrogen is planar as found for $\mathrm{R}^{\prime}=\mathrm{Ph}$.

The different $\sigma$-and $\pi$-properties of the two types of boryl substituent, $\mathrm{BR}_{2}$, can be interpreted via the frontier MOs of the corresponding dianions $\left[\mathrm{NBMe}_{2}\right]^{2-}$ and $\left[\mathrm{NB}(\mathrm{NMeCH})_{2}\right]^{2-}$ (Figure 9). The MOs of $[\mathrm{NMe}]^{2-}$ and $[\mathrm{NPh}]^{2-}$ computed

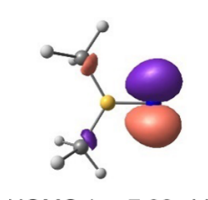

$\operatorname{HOMO}\left(\pi_{\mathrm{h}}, 7.32 \mathrm{eV}\right)$

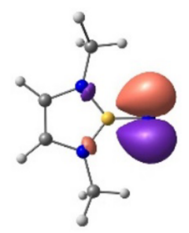

$\mathrm{HOMO}\left(\pi_{\mathrm{h}}, 6.81 \mathrm{eV}\right)$

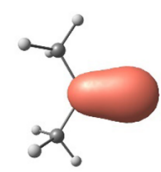

HOMO-1 $\left(\pi_{\mathrm{v}}, 5.79 \mathrm{eV}\right)$

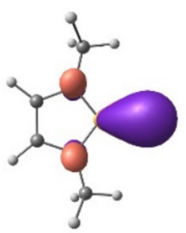

HOMO-1 $\left(\pi_{v}, 6.61 \mathrm{eV}\right)$

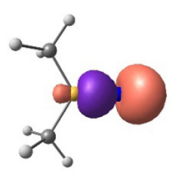

HOMO-2 $(\sigma, 4.76 \mathrm{eV})$

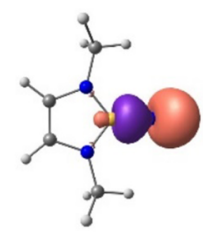

HOMO-2 $(\sigma, 4.50 \mathrm{eV})$
Figure 9. $\pi$ - and $\sigma$-type frontier molecular orbitals of the borylimido dianions $\left[\mathrm{NBMe}_{2}\right]^{2-}$ (top) and $\left[\mathrm{NB}(\mathrm{NMeCH})_{2}\right]^{2-}$ (bottom) in the geometry of $1 \mathbf{Q} \mathrm{BMe}_{2}$ and $1 \mathrm{Q} \mathbf{B}(\mathrm{NMeCH})_{2}$. Isosurfaces are drawn at the 0.075 au contour level.

with the same B3PW91/Def2-TZVP methodology are given for comparison in Figure S6 of the Supporting Information. As expected, the $\pi_{\mathrm{h}}$ and $\pi_{\mathrm{v}} \mathrm{MOs}$ of $\left[\mathrm{NBMe}_{2}\right]^{2-}$ have very different energies $(\Delta=1.53 \mathrm{eV})$ due to the $\mathrm{N}_{\text {im }}\left(2 \mathrm{p}_{\mathrm{v}}\right)-\mathrm{B}\left(2 \mathrm{p}_{\mathrm{v}}\right) \pi$ interaction. This difference is much smaller in $[\mathrm{NPh}]^{2-}(\Delta=$ $0.53 \mathrm{eV}$, Figure S6) and even less in $\left[\mathrm{NB}(\mathrm{NMeCH})_{2}\right]^{2-}(\Delta=$ $0.30 \mathrm{eV})$ due to $\mathrm{N}_{\mathrm{Me}}\left(2 \mathrm{p}_{\mathrm{v}}\right) \rightarrow \mathrm{B}\left(2 \mathrm{p}_{\mathrm{v}}\right)$ donation from the $\mathrm{N}_{\mathrm{Me}}$ lone pairs. As well as these $\pi$-effects from the electronegative $\mathrm{N}_{\mathrm{Me}}$ substituents, there is also a significant inductive effect which influences the $\left[\mathrm{NBR}_{2}\right]^{2-}$ orbital energies. Both the $\pi_{\mathrm{h}}$ (mainly boron $2 \mathrm{p} \mathrm{AO}$ character) and $\sigma$ (boron sp hybrid) MOs of $\left[\mathrm{NB}(\mathrm{NMeCH})_{2}\right]^{2-}$ are more stable than in $\left[\mathrm{NBMe}_{2}\right]^{2-}(\Delta=$ 0.51 and $0.26 \mathrm{eV}$, respectively).

The Ti-N $\mathrm{N}_{\mathrm{im}} \pi_{\mathrm{v}}$ and $\pi_{\mathrm{h}}$ MOs of $1 \mathbf{Q} \mathbf{B M e}_{2}$ and $\mathbf{1 Q} \mathbf{B}-$ $(\mathrm{NMeCH})_{2}$ are shown in Figure 57 of the Supporting Information, together with those of $1 \mathbf{Q ~} \mathbf{P h}$ for comparison. These show the expected general features, with $\pi_{\mathrm{h}}$ - and $\pi_{\mathrm{v}}$-type
$\mathrm{Ti}-\mathrm{N}_{\mathrm{im}}$ MOs being discernible. However, the relatively low symmetry of the complexes, mixing between $\mathrm{Ti}-\mathrm{Cp}$ and $\mathrm{Ti}-$ $\mathrm{NBR}_{2}$ bonding contributions in the lower energy $\pi_{\mathrm{v}}$ MOs, and also between the $\mathrm{Ti}-\mathrm{N}_{\mathrm{Me}}$ lone pairs and the $\mathrm{Ti}-\mathrm{N}_{\mathrm{im}} \pi_{\mathrm{h}}$ interaction prevents us from making more than a qualitative assessment.

In order to gain better insight into the relative bonding capabilities and the imide-amine exchange reactions we used the quantum theory of atoms in molecules (QTAIM) ${ }^{34}$ method together with computed bond dissociation energies for the metal complexes $\mathrm{CpTi}\left\{\mathrm{MeC}(\mathrm{NMe})_{2}\right\}(\mathrm{NR})\left(\Delta E_{\mathrm{Ti}-\mathrm{N}(\mathrm{R})}\right)$ and their corresponding amines $\mathrm{H}_{2} \mathrm{NR}\left(\Delta E_{2 \mathrm{H}-\mathrm{N}(\mathrm{R})}\right)$, as well as the optimized $\mathrm{Ti}-\mathrm{N}_{\mathrm{im}}$ and $\mathrm{N}_{\mathrm{im}}-\mathrm{R}$ distances. These data are given in Table 1 for the optimized complexes $1 \mathbf{Q} \mathbf{R}$, ordered principally according to the computed $\mathrm{Ti}-\mathrm{NR}$ bond dissociation energy. Table 2 provides a complementary set of QTAIM and selected NBO data for the same complexes but with $\mathrm{Ti}-$ $\mathrm{N}_{\text {im }}$ fixed at $1.70 \AA$ (1Q R f fxd) so as to better quantify the variations of QTAIM values with $\mathrm{N}_{\mathrm{im}}$ R-group alone. Graphical illustrations of the key parameter relationships are given in Figure 10, and Figures S8 and S9 of the Supporting Information.

Bond Length Trends. Comparison of the bond length trends for the $\mathrm{Ti}-\mathrm{N}_{\mathrm{im}-} \mathrm{R}$ moiety in the model compounds $1 \mathbf{Q} \mathbf{R}$ (Figure 7) with those of the previous and new X-ray structures for $\mathrm{Cp}^{*} \mathrm{Ti}\left(\kappa^{2}-\mathrm{L}^{\mathrm{N}_{2}}\right)(\mathrm{NR})\left(\mathrm{L}^{\mathrm{N}_{2}}=\mathrm{hpp}\right.$ or $\left.\mathrm{MeC}\left(\mathrm{N}^{\mathrm{i}} \mathrm{Pr}\right)_{2}\right)$ is a means to test the calculations against experiment, as well as probing underlying electronic factors in the absence of steric effects. To aid discussions we consider the variations in the bond lengths $d\left(\mathrm{Ti}-\mathrm{N}_{\mathrm{im}}\right)$ and $d\left(\mathrm{~N}_{\mathrm{im}}-\mathrm{R}\right)$ alongside the respective delocalization indices $(\delta)$, ellipticity $(\varepsilon)$, and net NR group charges $(\mathrm{Q}(\mathrm{NR}))$ from the QTAIM analysis. $\delta(\mathrm{A}-$ $B)$ for a bond pair " $A-B$ " is the number of electron pairs shared between the atoms, and is a measure of bond order for the same atomic types. The ellipticity measures the extent to which electron density is differentially accumulated in a given plane containing the bond path, and is 0 for a cylindrically symmetric bond.

The trends in $d\left(\mathrm{Ti}-\mathrm{N}_{\mathrm{im}}\right)$ and their approximate values for the model imides and hydrazides $\left(\mathrm{R}=\mathrm{Me}, \mathrm{Ar}, \mathrm{NMe}_{2}\right)$ follow that found previously by experiment. ${ }^{19}$ The increasing magnitude of $d\left(\mathrm{Ti}-\mathrm{N}_{\mathrm{im}}\right), \delta\left(\mathrm{N}_{\mathrm{im}}-\mathrm{R}\right)$ and $\varepsilon$, and decreasing $d\left(\mathrm{~N}_{\mathrm{im}}-\mathrm{R}\right), \delta\left(\mathrm{Ti}-\mathrm{N}_{\mathrm{im}}\right)$, and $\mathrm{Q}(\mathrm{NR})$, in the order $\mathrm{R}=\mathrm{Me}$, 4$\mathrm{C}_{6} \mathrm{H}_{4} \mathrm{NH}_{2}, \mathrm{Ph}, 4-\mathrm{C}_{6} \mathrm{H}_{4} \mathrm{CF}_{3}$ tracks the changes in delocalization of the $\pi_{\mathrm{v}}$ component of the $\mathrm{Ti}-\mathrm{N}_{\mathrm{im}}$ bond to the aryl ring. The corresponding changes in these values from $1 \mathbf{Q} \mathrm{NMe}_{2}$ pyram to $1 \mathbf{Q} \mathbf{N M e}_{2}$ planar (e.g., increase in $\varepsilon$ and $d\left(\mathrm{Ti}-\mathrm{N}_{\mathrm{im}}\right)$ and decrease in $\delta\left(\mathrm{Ti}-\mathrm{N}_{\mathrm{im}}\right)$ ) reflect increased lone pair donation from $\mathrm{N}_{\beta}$ to $\pi_{\mathrm{v}}^{*}$ of the Ti- $\mathrm{N}_{\mathrm{im}}$ bond in orbital terms.

The $\mathrm{Ti}-\mathrm{N}_{\mathrm{im}}$ distance for $\mathbf{1 Q} \mathbf{B M e}_{2}(1.706 \AA)$ is between that of $1 \mathbf{Q} \mathbf{P h}(1.702 \AA)$ and $\mathbf{1 Q} \mathbf{4}_{\mathbf{6}} \mathbf{H}_{\mathbf{4}} \mathbf{C F}_{3}(1.708 \AA)$, and longer than in $1 \mathrm{Q} \mathrm{Me}(1.679 \AA)$. This is in agreement with the $\mathrm{X}$-ray data for $\mathrm{Cp}{ }^{*} \mathrm{Ti}\left\{\mathrm{MeC}\left(\mathrm{N}^{\mathrm{i}} \mathrm{Pr}\right)_{2}\right\}\left(\mathrm{NBC}_{8} \mathrm{H}_{14}\right)$ (2), Cp*Ti$\left\{\mathrm{MeC}\left(\mathrm{N}^{\mathrm{i} P r}\right)_{2}\right\}(\mathrm{NXyl})^{28}$ and $\mathrm{Cp}{ }^{*} \mathrm{Ti}(\mathrm{hpp})\left(\mathrm{N}^{\mathrm{t} B u}\right)(\mathbf{1 8})$ (Ti$\mathrm{N}_{\text {im }}=1.731(3), 1.738(1)$, and 1.7081(18) $\AA$, respectively). The models find also that $d\left(\mathrm{Ti}-\mathrm{N}_{\mathrm{im}}\right)$ is slightly shorter for $1 \mathbf{Q} \mathbf{B}(\mathrm{NMeCH})_{2}$, whereas $d\left(\mathrm{Ti}-\mathrm{N}_{\mathrm{im}}\right)$ in $\mathrm{Cp} * \mathrm{Ti}(\mathrm{hpp})\{\mathrm{NB}-$ $\left.\left(\mathrm{NAr}^{\prime} \mathrm{CH}\right)_{2}\right\}(16,1.7433(19) \AA)$ is comparable within error to that in $\mathbf{2}$ and $\mathrm{Cp} * \mathrm{Ti}\left\{\mathrm{MeC}\left(\mathrm{N}^{\mathrm{i} P r}\right)_{2}\right\}(\mathrm{NXyl})$, presumably reflecting the large steric profile of the real $\mathrm{NB}\left(\mathrm{NAr}^{\prime} \mathrm{CH}\right)_{2}$ ligand in 16. Addition of $\mathrm{NH}_{3}$ to the boron atom of $1 \mathbf{Q} \mathbf{B M e}_{2}$ gives the hypothetical $\mathbf{1 Q} \mathbf{B M e}_{2} \mathbf{N H}_{3}\left(d\left(\mathrm{Ti}-\mathrm{N}_{\mathrm{im}}\right)=1.674 \AA\right)$ with a formally $\mathrm{sp}^{3}$ hybridized boron and no $2 \mathrm{p}_{\mathrm{v}} \pi$-acceptor 


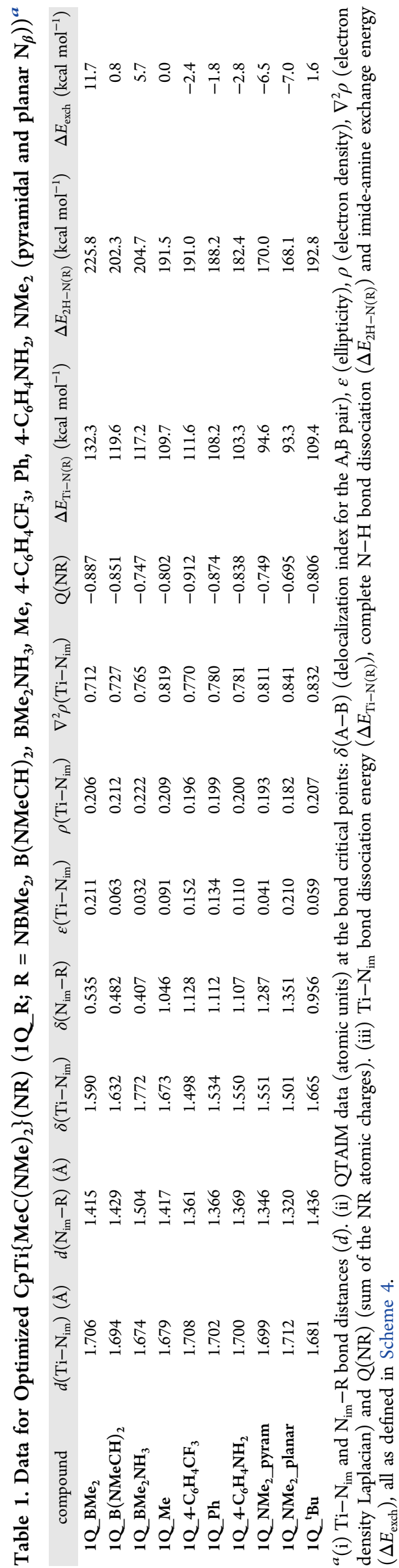

orbital. For comparison, we also computed the isoelectronic and isosteric $1 \mathbf{Q}^{\mathrm{t}} \mathrm{Bu}$, which has $d\left(\mathrm{Ti}-\mathrm{N}_{\mathrm{im}}\right)=1.681 \AA$, similar to that of 1 Me and $1 \mathrm{Q} \mathrm{BMe}_{2} \mathrm{NH}_{3}$.

The decrease in $d\left(\mathrm{Ti}-\mathrm{N}_{\mathrm{im}}\right)$ and corresponding increase in $d\left(\mathrm{~N}_{\mathrm{im}}-\mathrm{B}\right)$ from $1 \mathbf{Q} \mathbf{B M e}_{2}$ to $1 \mathbf{Q} \mathbf{B}(\mathbf{N M e C H})_{2}$ and then to $1 \mathrm{Q} \mathrm{BMe}_{2} \mathrm{NH}_{3}$ parallels the changing $\pi$-acceptor character of boron. The QTAIM data allow a quantitative evaluation of the relative $\pi$-effects. For example, $\varepsilon$ for $\mathrm{Ti}-\mathrm{N}_{\text {im }}$ in $\mathbf{1 Q} \mathbf{B M e}_{2}$ (0.211) is larger even than for $\mathbf{1 Q} \mathbf{4}-\mathbf{C}_{6} \mathbf{H}_{4} \mathbf{C F}_{3}$ (0.152), and much larger than in $\mathbf{1 Q} \mathbf{B}(\mathbf{N M e C H})_{2}(0.063)$. This $\varepsilon$ is comparable to that in $1 \mathbf{Q} \mathbf{B M e}_{2} \mathbf{N H}_{3}(\Delta=0.032)$ whose boron atom has no $2 \mathrm{p}_{\mathrm{v}} \pi$-acceptor orbital. The changes in the magnitudes of $d\left(\mathrm{Ti}-\mathrm{N}_{\mathrm{im}}\right), \delta\left(\mathrm{Ti}-\mathrm{N}_{\mathrm{im}}\right)$ and $Q(\mathrm{NR})$ from $1 Q \mathrm{BMe}_{2}$ to $1 \mathrm{Q} \mathrm{BMe}_{2} \mathrm{NH}_{3}(\Delta=0.032 \AA, 0.182$ and 0.140 e) are all significantly larger than from the isoelectronic $1 \mathbf{Q} \mathbf{~ P h}$ to $1 \mathrm{Q}^{\mathrm{t}} \mathrm{Bu}(\Delta=0.021 \AA, 0.010$ and $0.068 \mathrm{e})$. These QTAIM and metric data confirm that the $\mathrm{BMe}_{2} \mathrm{~N}_{\mathrm{im}}$-substituent (and dialkyl- or diaryl-boron in general) is a much better $\pi$-acceptor than a phenyl group, whereas the $\mathrm{B}(\mathrm{NMeCH})_{2}$ group (or its real homologues) is a less good acceptor even than an electronrich aryl group as modeled by $1 \mathrm{Q} \quad 4-\mathrm{C}_{6} \mathbf{H}_{4} \mathbf{N H}_{2}$.

The data in Table 1 for the fully optimized $1 \mathbf{Q} \mathbf{R}$ show that $d\left(\mathrm{Ti}-\mathrm{N}_{\mathrm{im}}\right)$ and $\delta\left(\mathrm{Ti}-\mathrm{N}_{\mathrm{im}}\right)$ are strongly correlated $\left(R^{2}=0.866\right.$, cf. Figure S8a in the Supporting Information). We also found that the $\mathrm{Ti}-\mathrm{N}_{\mathrm{im}}$ bonds of $\mathbf{1 Q} \mathbf{R}$ have a shallow potential energy surface. In a linear transit calculation, we found that $d\left(\mathrm{Ti}-\mathrm{N}_{\mathrm{im}}\right)$ for $1 \mathrm{Q}$ Me could be extended by ca. $0.04 \AA$ from its equilibrium value of 1.679 to $1.720 \AA$ (longer than any other 1Q $\mathbf{R} d\left(\mathrm{Ti}-\mathrm{N}_{\mathrm{im}}\right)$ value) at a cost of only $0.25 \mathrm{kcal} \mathrm{mol}^{-1}$ (and by up to $1.75 \AA$ with $\left.\Delta E=1.24 \mathrm{kcal} \mathrm{mol}^{-1}\right)$. The QTAIM parameters also change with $d\left(\mathrm{Ti}-\mathrm{N}_{\mathrm{im}}\right)$. For example, $\delta$ decreased from 1.673 to 1.629 and $\varepsilon$ increased from 0.091 to 0.111 on increasing $d\left(\mathrm{Ti}-\mathrm{N}_{\mathrm{im}}\right)$ for $1 \mathrm{Q}$ Me to 1.720 . In order to compare the QTAIM data for $1 \mathbf{Q} \mathbf{R}$ without the secondary effects from bond length changes we recalculated all of the systems with a fixed $\mathrm{Ti}-\mathrm{N}_{\mathrm{im}}$ bond length of $1.70 \AA$ (median value). These results are shown in Table 2 for the model compounds labeled $1 \mathbf{Q} \mathbf{R}$ fxd and correlate well with the those for $1 \mathbf{Q} \mathbf{R}$. Gratifyingly, we found that the $d\left(\mathrm{Ti}-\mathrm{N}_{\mathrm{im}}\right)$ values in optimized $1 \mathbf{Q} \mathbf{R}$ correlated well $\left(R^{2}=0.823\right)$ with the $\delta\left(\mathrm{Ti}-\mathrm{N}_{\mathrm{im}}\right)$ values in the fixed $\mathrm{Ti}-\mathrm{N}_{\mathrm{im}}$ bond distance series, $1 Q \mathbf{R}$ fxd as shown in Figure S8b. In most of the further discussions below we will refer to the $1 \mathbf{Q} \mathbf{R}$ fxd QTAIM parameters in order to extract cleanly the electronic effects of the various imide $\mathrm{R}$-substituents.

Bond Energies and Imide-Amine Exchange Energetics. The calculations for $\mathbf{1 Q} \mathbf{R}$ are consistent with $\mathrm{Ti}-\mathrm{N}_{\text {im }}$ bond lengths (and bond order as judged by $\delta\left(\mathrm{Ti}-\mathrm{N}_{\mathrm{im}}\right)$ ) being strongly influenced by the $\pi$-donor or $\pi$-acceptor ability of the $\mathrm{N}_{\text {im }}$ substituent. ${ }^{8 \mathrm{~b}, 17 \mathrm{a}, 35}$ On the other hand, lengthening $d(\mathrm{Ti}-$ $\mathrm{N}_{\mathrm{im}}$ ) in $1 \mathrm{Q}$ Me by over $0.07 \AA$ destabilized the compound only ca. $1.2 \mathrm{kcal} \mathrm{mol}^{-1}$, suggesting that $\mathrm{Ti}-\mathrm{N}_{\mathrm{im}}$ bond distance or bond order per se may not be reliable indicators of overall $\mathrm{Ti}-$ $\mathrm{N}_{\text {im }}$ bond strength. The well-behaved isodesmic imide-amine exchange reactions described above (Scheme 3 and eq 3 ) in principle provide experimental insight into the relative bond energetics of these imido and hydrazido compounds. We therefore computed (Table 1) the $\mathrm{Ti}-\mathrm{N}_{\mathrm{im}}$ bond dissociation energies $\left(\Delta E_{\mathrm{Ti}-\mathrm{N}(\mathrm{R})}\right)$ for $1 \mathbf{Q} \mathbf{R}$, as well as for the $2 \times \mathrm{H}-\mathrm{N}$ bond dissociation process $\mathrm{H}_{2} \mathrm{NR} \rightarrow 2 \mathrm{H}+\mathrm{NR}\left(\Delta E_{2 \mathrm{H}-\mathrm{N}(\mathrm{R})}\right)$ for the corresponding amines.

Table 1 shows that $\Delta E_{\mathrm{Ti}-\mathrm{N}(\mathrm{R})}$ increases generally in the order $\mathrm{R}=\mathrm{NMe}_{2}<$ aryl $<\mathrm{Me}<\mathrm{BR}_{2}$. There is no significant 
Table 2. Data for CpTi $\left\{\mathrm{MeC}(\mathrm{NMe})_{2}\right\}(\mathrm{NR})$ with $\mathrm{Ti}-\mathrm{N}_{\mathrm{im}}$ Fixed at $1.70 \AA$ (1Q R fxd; $\mathrm{R}=\mathrm{BMe}_{2}, \mathrm{~B}\left(\mathrm{NMeCH}_{2}, \mathrm{BMe}_{2} \mathrm{NH}_{3}, \mathrm{Me}\right.$, $4-\mathrm{C}_{6} \mathrm{H}_{4} \mathrm{CF}_{3}, \mathrm{Ph}, 4-\mathrm{C}_{6} \mathrm{H}_{4} \mathrm{NH}_{2}, \mathrm{NMe}_{2}$ (Pyramidal and Planar $\left.\left.\mathrm{N}_{\beta}\right)\right)^{a}$

\begin{tabular}{|c|c|c|c|c|c|c|c|c|c|c|}
\hline compound & $\delta$ & $\varepsilon$ & $\rho$ & $\nabla^{2} \rho$ & $H$ & $G / \rho$ & $\% \mathrm{Ti}$ in $\sigma \mathrm{NLMO}$ & $\mathrm{sp}^{x}$ of $\sigma \mathrm{NLMO}$ & $\% \mathrm{Ti}$ in $\pi_{\mathrm{h}}$ NLMO & $\% \mathrm{Ti}$ in $\pi_{\mathrm{v}} \mathrm{NLMO}$ \\
\hline $1 Q \mathrm{BMe}_{2}$ fxd & 1.596 & 0.208 & 0.210 & 0.719 & -0.114 & 1.400 & 20.4 & 1.94 & 30.2 & 17.2 \\
\hline $1 Q \mathrm{~B}(\mathrm{NMeCH})_{2}$ fxd & 1.627 & 0.063 & 0.209 & 0.722 & -0.113 & 1.405 & 19.4 & 1.53 & 26.1 & 25.7 \\
\hline $1 Q \mathrm{BMe}_{2} \mathrm{NH}_{3}$ f $\mathrm{fxd}$ & 1.749 & 0.032 & 0.208 & 0.740 & -0.112 & 1.428 & 20.3 & 1.05 & 25.8 & 30.0 \\
\hline 1Q Me_fxd & 1.653 & 0.096 & 0.199 & 0.793 & -0.101 & 1.508 & 18.0 & 0.64 & 28.7 & 29.1 \\
\hline 10 4- $\mathrm{C}_{6} \mathrm{H}_{4} \mathrm{CF}_{3} \_\mathrm{fxd}$ & 1.506 & 0.150 & 0.200 & 0.780 & -0.103 & 1.490 & 17.4 & 0.83 & 27.1 & 24.6 \\
\hline 1Q Ph_fxd & 1.536 & 0.133 & 0.200 & 0.783 & -0.103 & 1.494 & 17.6 & 0.81 & 27.4 & 25.8 \\
\hline $1 Q 4-\bar{C}_{6} \mathrm{H}_{4} \mathrm{NH}_{2}$ fxd & 1.549 & 0.111 & 0.200 & 0.781 & -0.103 & 1.491 & 17.5 & 0.78 & 27.1 & 26.9 \\
\hline $1 \mathrm{Q} \mathrm{NMe}_{2}$ pyram fxd & 1.550 & 0.041 & 0.192 & 0.809 & -0.095 & 1.545 & 17.0 & 0.45 & 25.2 & 34.1 \\
\hline $10 \mathrm{NMe}_{2}$ planar fxd & 1.515 & 0.205 & 0.188 & 0.859 & -0.089 & 1.618 & 16.7 & 0.51 & 22.9 & 37.2 \\
\hline
\end{tabular}

${ }^{a}(\mathrm{i})$ QTAIM data (atomic units) at the $\mathrm{Ti}-\mathrm{N}_{\mathrm{im}}$ bond critical points: $\delta$ (delocalization index), $\varepsilon$ (ellipticity), $\rho$ (electron density), $\nabla^{2} \rho$ (electron density Laplacian), $H$ (total energy density) and $G / \rho\left(G=\right.$ kinetic energy density). (ii) Percentage Ti participation (\% $\%$ i) in the stated $\mathrm{Ti}-\mathrm{N}_{\mathrm{im}}$ NLMOs, and proportion of $\mathrm{N}_{\mathrm{im}} 2 \mathrm{p}$ character $x$ in the $\mathrm{sp}^{x}$ hybrid orbital used to form the Ti- $\mathrm{N}_{\mathrm{im}} \sigma$-bond, as obtained from NBO calculations.
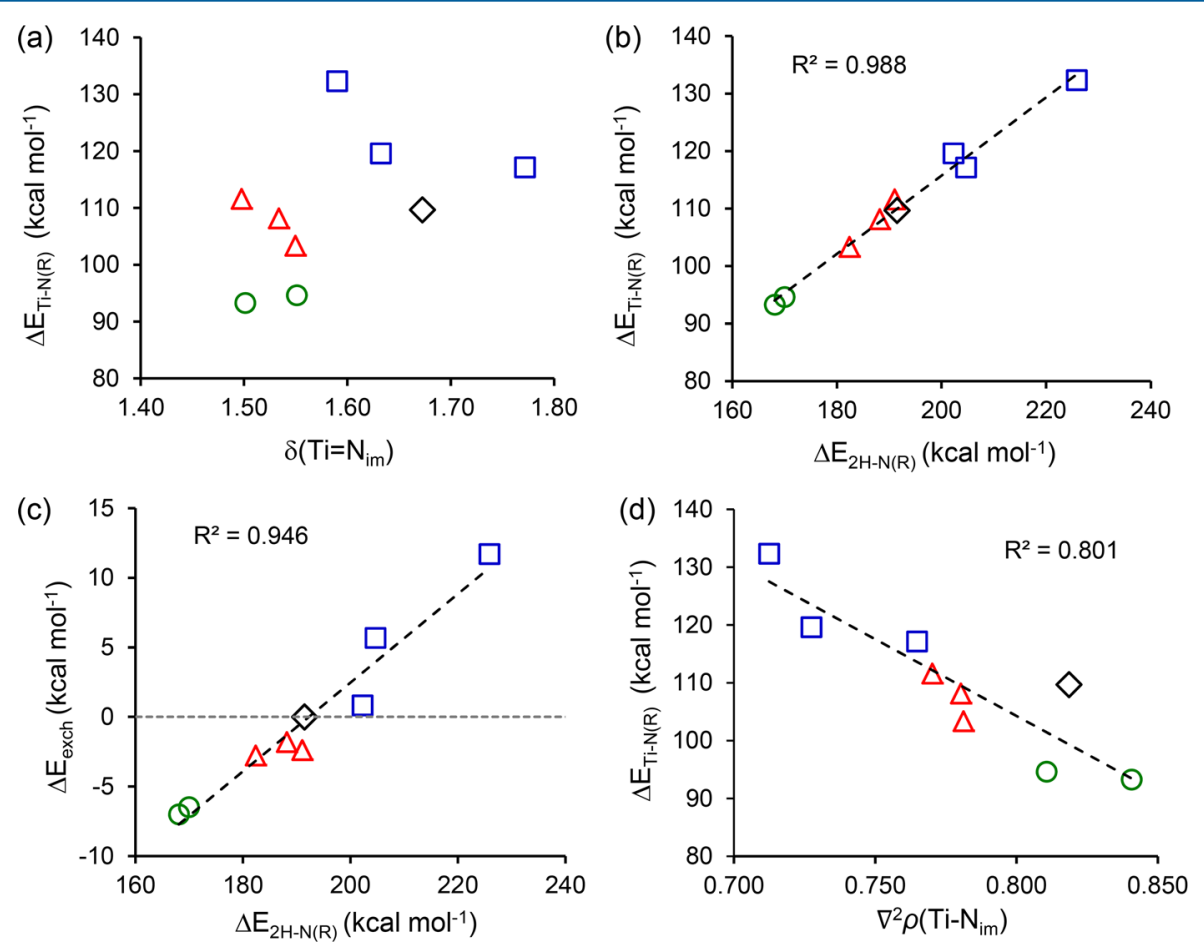

Figure 10. (a) Plot of $\Delta E_{\mathrm{Ti}-\mathrm{N}(\mathrm{R})}$ for $\mathrm{CpTi}\left\{\mathrm{MeC}(\mathrm{NMe})_{2}\right\}(\mathrm{NR})(\mathbf{1 Q} \mathbf{R})$ vs. $\delta\left(\mathrm{Ti}-\mathrm{N}_{\mathrm{im}}\right)$. (b) Plot of $\Delta E_{\mathrm{Ti}-\mathrm{N}(\mathrm{R})}$ for $\mathrm{CpTi}\left\{\mathrm{MeC}(\mathrm{NMe})_{2}\right\}(\mathrm{NR})$ $\left(1 \mathbf{Q}\right.$ R) vs. $\Delta E_{2 \mathrm{H}-\mathrm{N}(\mathrm{R})}$ for $\mathrm{H}_{2} \mathrm{NR}$ (c) Plot of $\Delta E_{\text {exch }}$ vs. $\Delta E_{2 \mathrm{H}-\mathrm{N}(\mathrm{R})}$. (d) Plot of $\Delta E_{\mathrm{Ti}-\mathrm{N}(\mathrm{R})}$ for $\mathrm{CpTi}\left\{\mathrm{MeC}(\mathrm{NMe})_{2}\right\}(\mathrm{NR})(\mathbf{1 Q} \mathbf{R})$ vs. $\nabla^{2} \rho\left(\mathrm{Ti}-\mathrm{N}_{\text {im }}\right)$. Key for all plots: blue squares, $\mathrm{R}=\mathrm{BMe}_{2}, \mathrm{~B}(\mathrm{NMeCH})_{2}, \mathrm{BMe}_{2} \mathrm{NH}_{3}$; black diamond, $\mathrm{R}=\mathrm{Me}$; red triangles, $\mathrm{R}=4-\mathrm{C}_{6} \mathrm{H}_{4} \mathrm{CF}_{3}, \mathrm{Ph}, 4-\mathrm{C}_{6} \mathrm{H}_{4} \mathrm{NH}_{2} ; g^{2}$ reen circles, $\mathrm{R}=\mathrm{NMe}_{2}$ (pyramidal and planar $\mathrm{N}_{\beta}$ ).

correlation $\left(R^{2} \approx 0.2\right)$ between $\Delta E_{\mathrm{Ti}-\mathrm{N}(\mathrm{R})}$ and either $d(\mathrm{Ti}-$ $\mathrm{N}_{\mathrm{im}}$ ) or $\delta\left(\mathrm{Ti}-\mathrm{N}_{\mathrm{im}}\right)$ (Figure $10 \mathrm{a}$ ) across the full range of compounds. In contrast, $\Delta E_{\mathrm{Ti}-\mathrm{N}(\mathrm{R})}$ for $\mathrm{CpTi}\left\{\mathrm{MeC}(\mathrm{NMe})_{2}\right\}$ (NR) $(1 \mathbf{Q} R)$ correlates very strongly with $\Delta E_{2 \mathrm{H}-\mathrm{N}(\mathrm{R})}$ for $\mathrm{H}_{2} \mathrm{NR}\left(R^{2}=0.988\right)$. Figure $10 \mathrm{~b}$ shows this relationship graphically. The gradient of the linear fit to the data from regression analysis is $0.32(3)$ showing that while both $\Delta E_{\mathrm{Ti}-\mathrm{N}(\mathrm{R})}$ and $\Delta E_{2 \mathrm{H}-\mathrm{N}(\mathrm{R})}$ increase in the same way with changing R-substituent, $\Delta E_{2 \mathrm{H}-\mathrm{N}(\mathrm{R})}$ increases faster.

The thermodynamic cycle in Scheme 4 allows the SCF energy $\left(\Delta E_{\text {exch }}\right)$ of imide-amine exchange to be calculated from the individual $\Delta E_{\mathrm{Ti}-\mathrm{N}(\mathrm{R})}$ and $\Delta E_{2 \mathrm{H}-\mathrm{N}(\mathrm{R})}$ data, which can then be tested against experiment. Figure 10c illustrates the strong linear relationship $\left(R^{2}=0.946\right)$ between $\Delta E_{\text {exch }}$ and $\Delta E_{2 \mathrm{H}-\mathrm{N}(\mathrm{R})}$. There is a similar relationship with $\Delta E_{\mathrm{Ti}-\mathrm{N}(\mathrm{R})}\left(R^{2}=0.886\right)$ but none with $d\left(\mathrm{Ti}-\mathrm{N}_{\mathrm{im}}\right)\left(R^{2}=0.09\right)$, for example. The horizontal line in Figure 10c intercepting the ordinate axis at $\Delta E_{\text {exch }}=0.0$ represents the thermoneutral exchange between $(\mathrm{L}) \mathrm{Ti}=\mathrm{NMe}$ and $\mathrm{H}_{2} \mathrm{NMe}$. Setting aside steric factors or kinetic limitations, and assuming $\Delta_{\mathrm{r}} S$ is relatively insignificant, any points which lie below the horizontal line represent electronically favorable reactions, while those above are unfavorable. The data match known experimental data well: titanium alkylimido ligands are readily substituted by anilines and hydrazines. ${ }^{1 \mathrm{c}, \mathrm{e}, 4 \mathrm{r}, 8 \mathrm{~b}}$ Within the arylimide systems alone, anilines with electron-withdrawing groups displace less electron-deficient arylimides ${ }^{35}$ (cf. $\Delta E_{\text {exch }}=$ $-0.58 \mathrm{kcal} \mathrm{mol}^{-1}\left(K_{\mathrm{eq}}=2.8\right)$ for $1 \mathrm{Q} \mathrm{Ph}+\mathrm{H}_{2} \mathrm{~N}-4-\mathrm{C}_{6} \mathrm{H}_{4} \mathrm{CF}_{3} \rightarrow$ $\left.1 \mathrm{Q} 4-\mathrm{C}_{6} \mathrm{H}_{4} \mathrm{CF}_{3}+\mathrm{H}_{2} \mathrm{NPh}\right)$. The DFT results are consistent with the borylimido results summarized in Scheme 3 and eq 3. Reaction of $\mathrm{Cp}^{*} \mathrm{Ti}(\mathrm{hpp})\left\{\mathrm{NB}\left(\mathrm{NAr}{ }^{\prime} \mathrm{CH}\right)_{2}\right\}\left(\right.$ 16) with $\mathrm{H}_{2} \mathrm{~N}^{\mathrm{t}} \mathrm{Bu}$ formed an equilibrium mixture with $\mathrm{Cp} \mathrm{p}^{*} \mathrm{Ti}(\mathrm{hpp})\left(\mathrm{N}^{\mathrm{t}} \mathrm{Bu}\right)(\mathbf{1 8})$ and borylamine 6 with experimental $\Delta_{\mathrm{r}} G=-1.0 \mathrm{kcal} \mathrm{mol}^{-1}$. Similarly, $\Delta E_{\text {exch }}=-0.83 \mathrm{kcal} \mathrm{mol}^{-1}$ for $1 \mathbf{Q} \mathbf{B}(\mathbf{N M e C H})_{2}+$ $\mathrm{H}_{2} \mathrm{NMe} \rightarrow 1 \mathbf{Q} \mathrm{Me}+\mathrm{H}_{2} \mathrm{NB}(\mathrm{NMeCH})_{2}$. The reaction between 


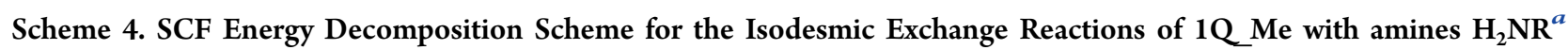

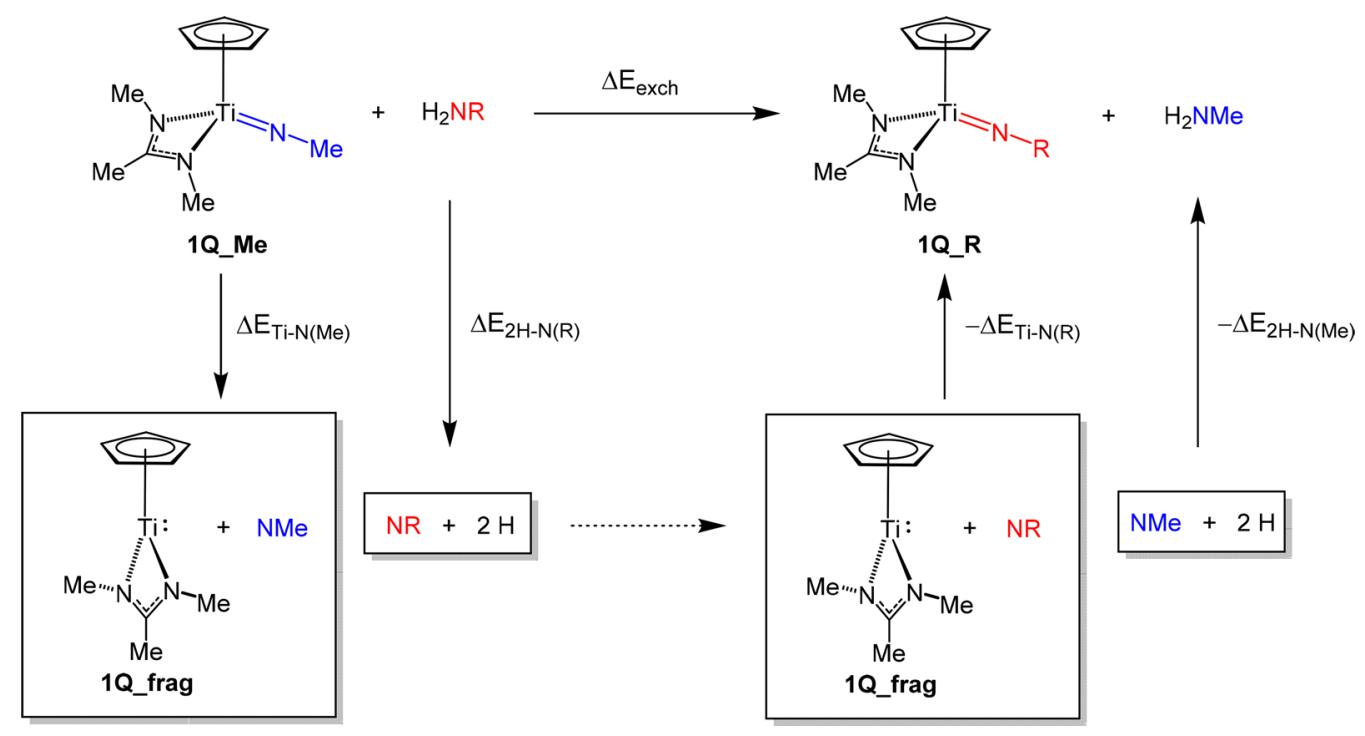

${ }^{a} \Delta E_{\text {exch }}=\Delta E_{\mathrm{Ti}-\mathrm{N}(\mathrm{Me})}+\Delta E_{2 \mathrm{H}-\mathrm{N}(\mathrm{R})}-\Delta E_{\mathrm{Ti}-\mathrm{N}(\mathrm{R})}-\Delta E_{2 \mathrm{H}-\mathrm{N}(\mathrm{Me})}$. All fragments are in their relaxed geometries for an $S=1$ spin state except for $\mathrm{H}(S=$ $1 / 2)$.

$\mathrm{Cp} * \mathrm{Ti}\left\{\mathrm{MeC}\left(\mathrm{N}^{\mathrm{i} P r}\right)_{2}\right\}\left(\mathrm{NBC}_{8} \mathrm{H}_{14}\right)$ and $\mathrm{H}_{2} \mathrm{~N}^{\mathrm{t}} \mathrm{Bu}$ is quantitative in favor of $\mathrm{Cp}^{*} \mathrm{Ti}\left\{\mathrm{MeC}\left(\mathrm{N}^{\mathrm{i}} \mathrm{Pr}\right)_{2}\right\}\left(\mathrm{N}^{\mathrm{t}} \mathrm{Bu}\right)$ (eq 3), while $\Delta E_{\text {exch }}=$ $-11.7 \mathrm{kcal} \mathrm{mol}^{-1}$ for $1 \mathrm{Q} \mathbf{B M e}_{2}+\mathrm{H}_{2} \mathrm{NMe} \rightarrow \mathbf{Q Q} \mathbf{M e}+$ $\mathrm{H}_{2} \mathrm{NBMe}_{2}$.

Bond Energies and QTAIM Parameters. To gain a better understanding of the computed trends in $\mathrm{Ti}-\mathrm{N}_{\mathrm{im}}$ bond energies, we turned again to the QTAIM data. Specifically, the signs and magnitude of the electron density $(\rho)$, its Laplacian $\left(\nabla^{2} \rho\right)$ and the total energy density $(H)$ at the bond critical point of a bond " $\mathrm{A}-\mathrm{B}$ " can all give indications of $\mathrm{A}-\mathrm{B}$ bond strengths. Table 1 gives $\nabla^{2} \rho$ data for the optimized $1 \mathbf{Q} \mathbf{R}$ systems, and Table 2 provides a wider set of QTAIM parameters for the $1 \mathbf{Q} \mathbf{R}$ fxd series where we separate out the electronic effects of the imido R-group from small perturbations with changing $d\left(\mathrm{Ti}-\mathrm{N}_{\mathrm{im}}\right)$. The values of $G / \rho$ ( $G=$ kinetic energy density), which can relate to bond polarity, are also listed in Table 2 .

In general, the magnitudes of $\rho$ and $H$ at the bond critical points, and the positive value of the electron density Laplacian $\left(\nabla^{2} \rho\right)$ are consistent with the expected polar, covalent $\mathrm{Ti}-\mathrm{N}_{\mathrm{im}}$ bonds in $1 \mathbf{Q} \mathbf{R}$ and $1 \mathbf{Q} \mathbf{R}$ fxd. Figure 10d illustrates the linear negative relationship $\left(R^{2}=0.801\right)$ between $\Delta E_{\mathrm{Ti}-\mathrm{N}(\mathrm{R})}$ and $\nabla^{2} \rho$ for $1 \mathbf{Q} \mathbf{R}$; the corresponding plot for $\mathbf{1 Q} \mathbf{R}$ fxd (Figure S9a) has $R^{2}=0.834 . \nabla^{2} \rho$ is a measure of the concentration of electron density at the bond critical point (BCP). A more negative value of $\nabla^{2} \rho$ indicates a higher degree of covalency for a homologous series of compounds. $\nabla^{2} \rho$ is in fact the sum of three curvatures of electron density $\left(\lambda_{n}, n=1,2,3\right)$ at the BCP. Table $S 1$ of the Supporting Information gives the breakdown for these values for $1 \mathbf{Q} \mathbf{R}$ fxd. $\lambda_{1}$ and $\lambda_{2}$ reflect the concentration of electron density along the bond path. They are negative for all $\mathbf{1 Q} \mathbf{R}$ fxd, and become increasingly negative with $\Delta E_{\mathrm{Ti}-\mathrm{N}(\mathrm{R})}\left(\mathrm{av} . R^{2}=0.878\right)$. Furthermore, the values of $\rho, H$, and $G / \rho$ (Table S2, Figure S9) all correlate with $\Delta E_{\mathrm{Ti}-\mathrm{N}(\mathrm{R})}\left(R^{2}=0.839-0.874\right)$ in a way that points to increasing covalency and bond strength, and decreasing $\mathrm{Ti}-$ $\mathrm{N}_{\text {im }}$ polarity, in the order $\mathrm{R}=\mathrm{NMe}_{2}$ (least covalent) < aryl < $\mathrm{Me}<\mathrm{BR}_{2}$ (most covalent), regardless of $d\left(\mathrm{Ti}-\mathrm{N}_{\mathrm{im}}\right)$ or $\delta(\mathrm{Ti}-$ $\mathrm{N}_{\mathrm{im}}$ ).
To relate these results back to orbital interpretations we analyzed the electronic structures of $1 \mathbf{Q} \mathbf{R}$ fxd using the NBO method. ${ }^{7,36}$ This approach aids interpretation of the bonding in terms of idealized Lewis structures. The NBO calculations were set up with the $\sigma$-and $\pi$-donor NBOs of $\mathrm{N}_{\text {im }}$ described formally as lone pairs donating to acceptor NBOs on titanium, ultimately forming the $\sigma-, \pi_{\mathrm{h}}-$, and $\pi_{\mathrm{v}}-\mathrm{NLMOs}$ of the Ti$\mathrm{N}_{\text {im }}$ triple bonds (NLMO = natural localized MO). The NLMOs of $1 \mathbf{Q} \mathbf{B M e}_{2}$ fxd are shown by way of example in Figure S10 of the Supporting Information.

Table 2 gives the extent of Ti participation (expressed as \% $\mathrm{Ti}$ orbital character) in these various NLMOs, and the proportion of $\mathrm{N}_{\mathrm{im}}$ atom $2 \mathrm{p}$ character $x$ in the $\mathrm{sp}^{x}$ hybrid donor orbital contributing to the Ti- $\mathrm{N}_{\mathrm{im}} \sigma$-bond. The \% Ti in the $\sigma$ and $\pi_{\mathrm{h}}$ NLMOs increases with $\mathrm{Ti}-\mathrm{N}_{\mathrm{im}}$ bond covalency as judged by negative correlations with $\nabla^{2} \rho$ (larger \% Ti for less positive $\left.\nabla^{2} \rho\right)$. The degree of $\mathrm{N}_{\mathrm{im}} 2 \mathrm{p}$ character also increases significantly with decreasing $\nabla^{2} \rho$. For example, the $\sigma$-bond for $1 Q \mathrm{BMe}_{2}$ fxd is formed using a $\mathrm{sp}^{1.6}$-hybridized $\mathrm{N}_{\mathrm{im}}$ hybrid, whereas that for $\mathbf{1 Q} \mathbf{N M e}_{2}$ planar fxd is formed with a $\mathrm{sp}^{0.51} \mathrm{~N}_{\mathrm{im}}$ hybrid orbital (Bent's rule ${ }^{37}$ predicts that $\mathrm{N}_{\mathrm{im}}$ $2 s$ character would accumulate preferentially toward more electropositive R-group bond partners). The increased $\mathrm{N}_{\mathrm{im}} 2 \mathrm{p}$ character in the $\sigma$-bonding NBO has the effect of polarizing this donor orbital toward $\mathrm{Ti}$, improving the $\sigma$-donor ability of $\mathrm{NR}$. The bond dissociation energies $\Delta E_{\mathrm{Ti}-\mathrm{N}(\mathrm{R})}$ scale linearly with \% $\mathrm{Ti}$ in the $\sigma$ - and $\pi_{\mathrm{h}}$-donor NLMOs and with the $x$ value of $\mathrm{sp}^{x}$ (Figures S9e $\left(R^{2}=0.798\right)$ and S9f $\left.\left(R^{2}=0.859\right)\right)$.

Whereas \% Ti generally increases in the $\sigma$ - and $\pi_{\mathrm{h}}$-NLMO from $1 Q \mathrm{NMe}_{2}$ planar_fxd to $1 \mathrm{Q} \mathrm{BMe}_{2}$ fxd, the position for the $\pi_{\mathrm{v}}$-NLMO is different and is dominated by the $\pi$ bonding character of $\mathrm{R}$. \% $\mathrm{Ti}$ decreases substantially from $1 \mathrm{Q} \mathrm{B}(\mathrm{NMeCH})_{2}$ fxd (25.7) to $10 \mathrm{BMe}_{2}$ fxd (17.2\%), and slightly from 1Q $4-\mathrm{C}_{6} \mathbf{H}_{4} \mathbf{N H}_{2}$ fxd $(26.9 \%)$ to $\mathbf{1 Q}$ 4$\mathbf{C}_{6} \mathbf{H}_{4} \mathbf{C F}_{3}$ fxd (24.6\%) as expected, showing that $\pi_{\mathrm{v}}$ becomes more ligand-based. Analogously, \% $\mathrm{Ti}$ increases from $1 \mathrm{Q} \mathrm{NMe}_{2} \_$pyram_fxd (34.1\%) to $1 \mathrm{Q} \mathrm{NMe}_{2}$ planar_fxd (37.1\%). Overall there is a negative correlation $\left(R^{2}=0 . \overline{873}\right)$ between $\Delta E_{\mathrm{Ti}-\mathrm{N}(\mathrm{R})}$ and $\% \mathrm{Ti}$ (and a modest positive correlation 
$\left(R^{2}=0.774\right)$ between $\nabla^{2} \rho$ and $\left.\% \mathrm{Ti}\right)$ for those $1 \mathbf{Q} \mathbf{R}$ planar_fxd systems which have significant R-group $\pi$-character. This reflects the $\mathrm{Ti}-\mathrm{N}_{\mathrm{im}}$ bond weakening effect of both $\pi$ acceptor and $\pi$-donor $\mathrm{N}_{\mathrm{im}}$ substituents.

Synthesis and Structures of Bis(cyclopentadienyl) titanium Borylimido Compounds. A wide range of metal-ligand multiply bonded Group 4 metallocenes of the type $\mathrm{Cp}_{2}^{\mathrm{R}}{ }_{2} \mathrm{M}(\mathrm{E})(\mathrm{L})(\mathrm{M}=\mathrm{Ti}, \mathrm{Zr}, \mathrm{Hf} ; \mathrm{E}=\mathrm{NR}, \mathrm{PR}, \mathrm{O}, \mathrm{S}, \mathrm{Se}, \mathrm{Te}$; $\mathrm{L}=$ Lewis base) have been previously reported. ${ }^{2 \mathrm{a}, 3 \mathrm{~h}, 38}$ These are interesting, both in terms of reactivity and of their electronic structure, being so-called " $\pi$-loaded" (formally 20 valence electron) compounds. We have previously shown that both the tert-butylimide $\mathrm{Cp}_{2} \mathrm{Ti}\left(\mathrm{N}^{\mathrm{t}} \mathrm{Bu}\right)(\mathrm{py})$ (21) and diphenylhydrazide $\mathrm{Cp}_{2} \mathrm{Ti}\left(\mathrm{NNPh}_{2}\right)$ (py) (22) can be prepared from the respective $\mathrm{Ti}(\mathrm{NR}) \mathrm{Cl}_{2}(\mathrm{py})_{3}$ precursor $\left(\mathrm{R}={ }^{\mathrm{t}} \mathrm{Bu}\right.$ or $\left.\mathrm{NPh}_{2}\right){ }^{3 \mathrm{~h}, 38 \mathrm{a}}$ Gratifyingly, reaction of $\mathrm{Ti}\left\{\mathrm{NB}\left(\mathrm{NAr}^{\prime} \mathrm{CH}\right)_{2}\right\} \mathrm{Cl}_{2}(\mathrm{py})_{3}$ (9) with two equiv of $\mathrm{NaCp}$ formed the corresponding titanocene borylimide $\mathrm{Cp}_{2} \mathrm{Ti}\left\{\mathrm{NB}\left(\mathrm{NAr}^{\prime} \mathrm{CH}\right)_{2}\right\}(\mathrm{py})(23)$ in $58 \%$ isolated yield (eq 4 ). The ${ }^{1} \mathrm{H}$ and ${ }^{13} \mathrm{C}$ NMR spectra of 23 are consistent

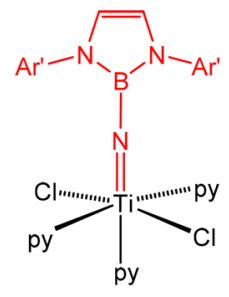

9

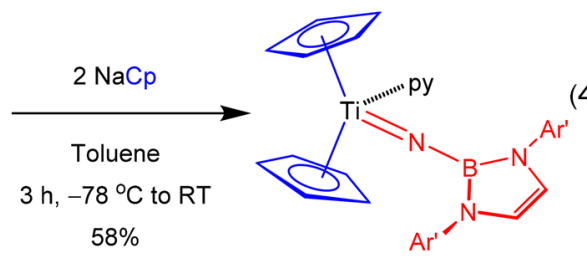

23 with the proposed structure, and the borylimido ligand gave a singlet at $18.0 \mathrm{ppm}$ in the ${ }^{11} \mathrm{~B}$ NMR spectrum, consistent with all the other borylimides of this type discussed above. As mentioned, the reaction of 9 with 1 equiv of $\mathrm{NaCp}$ did not cleanly form the target half-sandwich compound CpTi\{NB$\left.\left(\mathrm{NAr}^{\prime} \mathrm{CH}\right)_{2}\right\} \mathrm{Cl}$ (py) (24). However, we were able to prepare 24 through a redistribution reaction between 9 and 23 at $70{ }^{\circ} \mathrm{C}$ over 5 days. Full details are provided in the Supporting Information.

Diffraction-quality crystals of $\mathbf{2 3}$ were grown from pentane at $5{ }^{\circ} \mathrm{C}$. The solid state structure is shown in Figure 11, along with selected bond distances and angles. Molecules of 23 contain a bent $\mathrm{Cp}_{2} \mathrm{Ti}$ moiety which is coordinated to both the borylimido ligand and a pyridine donor ligand. Although this is the first borylimido sandwich compound of any metal, its structure may be compared to other Group 4 metallocenes of the type $\mathrm{Cp}^{\mathrm{R}}{ }_{2} \mathrm{M}(\mathrm{E})(\mathrm{L})$. The $\mathrm{Cp}$ rings of $\mathbf{2 3}$ are best described as $\eta^{5}$ coordinated to the metal with $\mathrm{Ti}-\mathrm{C}$ bonds in the range 2.4022(18)-2.6053(18) $\AA$, and an average $\mathrm{Ti}-\mathrm{Cp}_{\text {cent }}$ distance of $2.18 \pm 0.04 \AA$ (av. of 2.14 and $2.22 \AA$ ). These values are comparable to those in the analogous tert-butylimide $\mathrm{Cp}_{2} \mathrm{Ti}$ $\left(\mathrm{N}^{\mathrm{t}} \mathrm{Bu}\right)(\mathrm{py})(21$, av. $2.22 \AA)$ and hydrazide $\mathrm{Cp}_{2} \mathrm{Ti}\left(\mathrm{NNPh}_{2}\right)(\mathrm{py})$ (22, av. $2.18 \AA)^{3 \mathrm{~h}, 38 \mathrm{a}}$ They are, however, ca. $0.1 \AA \AA$ longer than the $\mathrm{Ti}-\mathrm{Cp}_{\text {cent }}$ distances generally found in titanocene complexes of the type $\mathrm{Cp}_{2}{ }_{2} \mathrm{TiX}_{2}\left(\mathrm{X}=\mathrm{Cl}\right.$, alkyl), ${ }^{19}$ because of the $\pi$-loaded nature of these compounds. The "upper" $\mathrm{Cp}$ ring (as drawn in Figure 11) of $\mathbf{2 3}$ has a noticeable ring-slip toward $\eta^{3}$-coordination $(\mathrm{Ti}(1)-\mathrm{C}(28)$ and $\mathrm{Ti}(1)-\mathrm{C}(29)=$ $2.6050(18)$ and 2.6053(18) $\AA$, respectively), whereas all of the other $\mathrm{Ti}-\mathrm{C}$ lengths in this and the "lower" $\mathrm{Cp}$ ring are in the range ca. $2.402-2.503 \AA$. The $\operatorname{Ti}(1)-\mathrm{N}(1)$ bond length of $1.7549(13) \AA$ and $C \mathrm{p}_{\text {cent }}-\mathrm{Ti}-\mathrm{Cp}_{\text {cent }}$ angle of $125.1^{\circ}$ is comparable to the $\mathrm{Ti}-\mathrm{N}_{\mathrm{im}}$ distance in the hydrazide 22

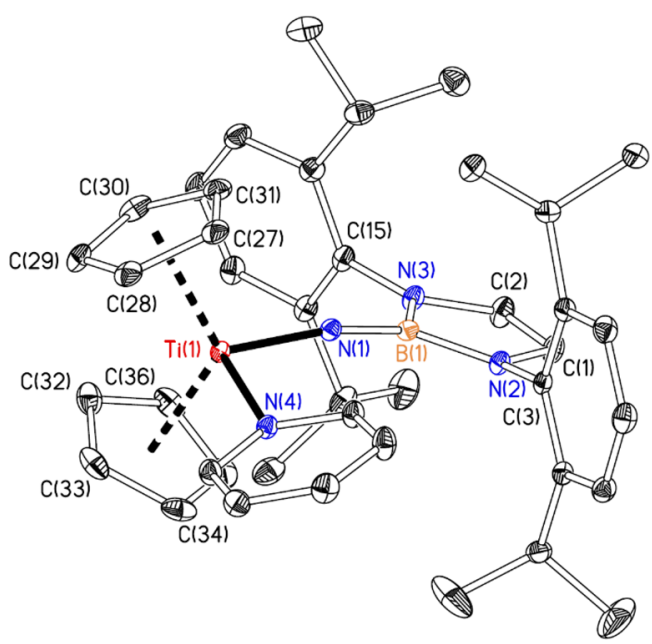

Figure 11. Displacement ellipsoid plot (20\% probability) of $\mathrm{Cp}_{2} \mathrm{Ti}\left\{\mathrm{NB}\left(\mathrm{NAr} \mathrm{r}^{\prime} \mathrm{CH}\right)_{2}\right\}$ (py) (23). $\mathrm{H}$ atoms are omitted for clarity. Selected bond distances $(\AA)$ and angles $\left({ }^{\circ}\right)$ : $\mathrm{Ti}(1)-\mathrm{N}(1)$ 1.7549(13), $\mathrm{Ti}(1)-\mathrm{N}(4)$ 2.2523(14), $\mathrm{Ti}(1)-\mathrm{Cp}_{\text {cent }(1)} 2.22, \mathrm{Ti}(1)-\mathrm{Cp}_{\text {cent(2) }}$ 2.14, $\mathrm{N}(1)-\mathrm{B}(1)$ 1.426(2), $\mathrm{Cp}_{\text {cent }(1)}-\mathrm{Ti}(1)-\mathrm{N}(1) 113.8, \mathrm{Cp}_{\text {cent }(2)}-\mathrm{Ti}(1)-$ $\mathrm{N}(1)$ 111.3, $\mathrm{Cp}_{\text {cent(1) }}-\mathrm{Ti}(1)-\mathrm{N}(4)$ 99.2, $\mathrm{Cp}_{\text {cent(2) }}-\mathrm{Ti}(1)-\mathrm{N}(4)$ 106.4, $C \mathrm{p}_{\text {cent }(1)}-\mathrm{Ti}(1)-\mathrm{C} \mathrm{p}_{\text {cent }(2)} 125.1, \mathrm{~N}(1)-\mathrm{Ti}(1)-\mathrm{N}(4)$ 95.11(5), Ti(1)$\mathrm{N}(1)-\mathrm{B}(1)$ 159.65(12). $\mathrm{Cp}_{\text {cent }(1)}$ and $\mathrm{Cp}_{\text {cent }(2)}$ refer to the centroids for the $C p$ ring carbons $C(27)-C(31)$ and $C(32)-C(36)$, respectively.

$\left(1.757(2) \AA, \mathrm{Cp}_{\text {cent }}-\mathrm{Ti}-\mathrm{Cp}_{\text {cent }}=123.8^{\circ}\right),{ }^{3 \mathrm{~h}}$ and longer than in $21\left(1.723(6) \AA, C p_{\text {cent }}-\mathrm{Ti}-\mathrm{Cp}_{\text {cent }}=121.3^{\circ}\right){ }^{38 \mathrm{a}}$ These compounds also showed partial slippages of one of the $\mathrm{Cp}$ rings.

Bergman and Andersen have previously shown ${ }^{39}$ that the base-free imide $\mathrm{Cp}^{*}{ }_{2} \mathrm{Ti}(\mathrm{NPh})$ could be prepared from $\mathrm{Cp}{ }_{2}{ }_{2} \mathrm{Ti}\left(\eta-\mathrm{C}_{2} \mathrm{H}_{4}\right)$ and $\mathrm{PhN}_{3}$, although only limited details of the solid state structure are available. Chirik subsequently found that the dinitrogen compound $\left(\mathrm{Cp}^{\prime \prime}{ }_{2} \mathrm{Ti}\right)_{2}\left(\mu_{2}: \eta^{1}, \eta^{1}-\mathrm{N}_{2}\right)(\mathbf{2 5}, \mathrm{Cp}$ " $\left.=1,3-\mathrm{C}_{5} \mathrm{H}_{3}\left(\mathrm{SiMe}_{3}\right)_{2}\right)$ reacts with certain azides to form $\mathrm{Cp}^{\prime \prime}{ }_{2} \mathrm{Ti}(\mathrm{NR})\left(\mathrm{R}=\mathrm{SiMe}_{3}\right.$ (X-ray structure) or Xyl); Rosenthal, Schulz, and Jemmis very recently reported the $\mathrm{X}$-ray structure of the arylimide $\mathrm{Cp}^{*}{ }_{2} \mathrm{Ti}\left(\mathrm{NAr}^{\prime}\right)\left(\mathrm{Ar}^{\prime}=2,6-\mathrm{C}_{6} \mathrm{H}_{3}{ }^{\mathrm{i}} \mathrm{Pr}_{2}\right)$, formed from $\mathrm{Cp}^{*}{ }_{2} \mathrm{Ti}\left\{\eta-\mathrm{C}_{2}\left(\mathrm{SiMe}_{3}\right)_{2}\right\}$ and $\mathrm{Ar}^{\prime} \mathrm{NCNAr}^{\prime}{ }^{40}$

Inspired by these results and Wilkinson ${ }^{12 a}$ and Sundermeyer's $^{12 b}$ reports of accessing certain Group 5 and 6 borylimides by reaction of lower oxidation state precursor complexes with $\mathrm{N}_{3} \mathrm{BMes}_{2}$, we carried out an analogous reaction of 25 with $\mathrm{N}_{3} \mathrm{BMes}_{2}$ in toluene at $-78{ }^{\circ} \mathrm{C}$. After warming to room temperature and workup, the base-free titanocene borylimido complex $\mathrm{Cp}^{\prime \prime}{ }_{2} \mathrm{Ti}\left(\mathrm{NBMes}_{2}\right)$ (26, eq 5) was isolated as a green powder in $70 \%$ yield. The ${ }^{1} \mathrm{H}$ and ${ }^{13} \mathrm{C}$ NMR spectra of $\mathbf{2 6}$ in toluene- $d_{8}$ solution are consistent with a $C_{s}$ symmetric species having one dimesitylborylimido ligand and two $\mathrm{Cp}$ " groups. The ${ }^{11} \mathrm{~B}$ NMR shift $(44.2 \mathrm{ppm})$ is much more positive than that of $23(18.0 \mathrm{ppm})$ or the other complexes reported above that contain $\mathrm{NB}\left(\mathrm{NAr}^{\prime} \mathrm{CH}\right)_{2}$ ligands (range ca. 14-18 ppm), but less than in $\mathrm{Cp}{ }^{*} \mathrm{Ti}\left\{\mathrm{MeC}\left(\mathrm{N}^{\mathrm{i}} \mathrm{Pr}\right)_{2}\right\}\left(\mathrm{NBC}_{8} \mathrm{H}_{14}\right)$ $52.8 \mathrm{ppm})$. These variations mainly reflect the nature of the boron substituents. The experimental ${ }^{11} \mathrm{~B}$ NMR shifts for monomeric (trigonal planar) $\mathrm{H}_{2} \mathrm{NBMes}_{2}$ and $\mathrm{H}_{2} \mathrm{NB}\left(\mathrm{NAr}{ }^{\prime} \mathrm{CH}\right)_{2}$ are 44.5 and $22.9 \mathrm{ppm}$ in $\mathrm{C}_{6} \mathrm{D}_{6}$ (DFT calculated 47.1 and 23.0 ppm). As mentioned, " $\mathrm{H}_{2} \mathrm{NBC}_{8} \mathrm{H}_{14}$ " exists as a dimer in solution and the solid state: experimental ${ }^{11} \mathrm{~B}$ shift $-1.7 \mathrm{ppm}$ (DFT - $4.6 \mathrm{ppm})$ in $\mathrm{C}_{6} \mathrm{D}_{6}$ indicating 4-coordinate boron. ${ }^{41}$ 

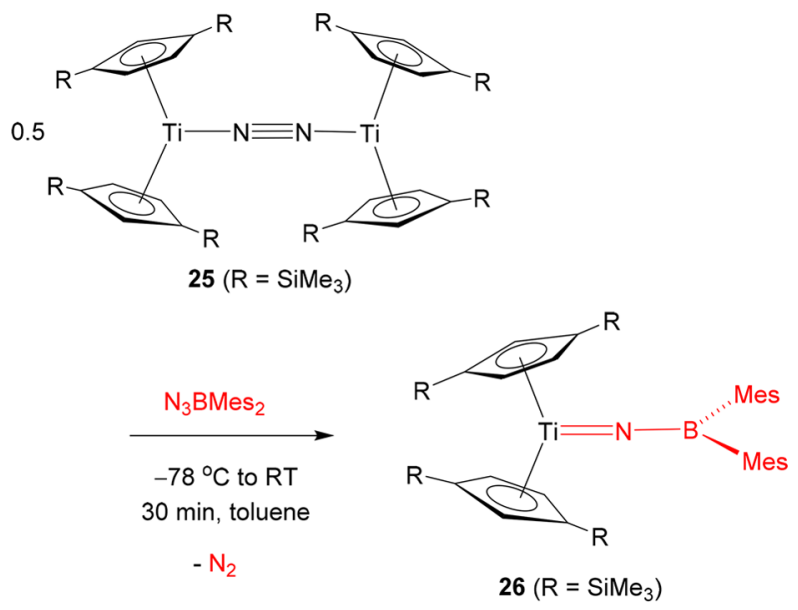

Therefore, a direct experimental comparison with 2 cannot be made. However, the DFT calculated value of $53.8 \mathrm{ppm}$ for monomeric $\mathrm{H}_{2} \mathrm{NBC}_{8} \mathrm{H}_{14}$ is in good agreement with the trend found in the borylimides themselves.

Diffraction-quality crystals of $\mathbf{2 6}$ were grown from hexane at $4{ }^{\circ} \mathrm{C}$. The solid state structure is shown in Figure 12, along with

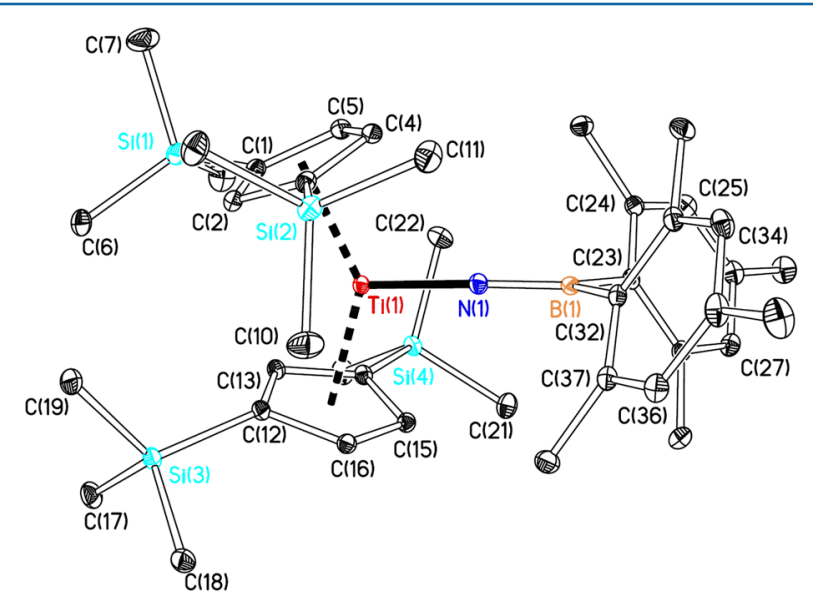

Figure 12. Displacement ellipsoid plot (20\% probability) of $\mathrm{Cp}^{\prime \prime}{ }_{2} \mathrm{Ti}\left(\mathrm{NBMes}_{2}\right)$ (26). $\mathrm{H}$ atoms are omitted for clarity. Selected bond distances $(\AA)$ and angles $\left({ }^{\circ}\right): \operatorname{Ti}(1)-\mathrm{N}(1)$ 1.8069(7), $\mathrm{Ti}(1)-$ $\mathrm{Cp}_{\text {cent(1) }}$ 2.08, $\mathrm{Ti}(1)-\mathrm{Cp}_{\text {cent }(2)} 2.08, \mathrm{~N}(1)-\mathrm{B}(1)$ 1.3782(12), $\mathrm{Cp}_{\text {cent }(1)}-\mathrm{Ti}(1)-\mathrm{N}(1) \quad$ 109.7, $\quad \mathrm{Cp}_{\text {cent }(2)}-\mathrm{Ti}(1)-\mathrm{N}(1)$ 109.9, $\mathrm{Cp}_{\text {cent }(1)}-\mathrm{Ti}(1)-\mathrm{C}_{\text {cent }(2)} 140.5, \operatorname{Ti}(1)-\mathrm{N}(1)-\mathrm{B}(1) \quad 175.7(1)$. $\mathrm{Cp}_{\text {cent }(1)}$ and $\mathrm{Cp}_{\text {cent }(2)}$ refer to the centroids for $\mathrm{Cp}^{\prime \prime}$ ring carbons $C(1)-C(5)$ and $C(12)-C(16)$, respectively.

selected bond distances and angles. Compound 26 is a monomeric, base-free species containing a bent $\mathrm{Cp}^{\prime \prime}{ }_{2} \mathrm{Ti}$ moiety bonded to a $\mathrm{NBMes}_{2}$ ligand. The mesityl rings are rotated ca. $65^{\circ}$ out of the $\{\mathrm{N}(1), \mathrm{B}(1), \mathrm{C}(23,32)\}$ least-squares plane, indicating little conjugation of the aromatic rings with the $\mathrm{Ti}(1)-\mathrm{N}(1)-\mathrm{B}(1)$ linkage. The $\mathrm{Ti}(1)-\mathrm{N}(1)$ distance of $1.8069(7) \AA$ is significantly longer than the corresponding value in $\mathrm{Cp}_{2} \mathrm{Ti}\left\{\mathrm{NB}\left(\mathrm{NAr}^{\prime} \mathrm{CH}\right)_{2}\right\}$ (py) (23), and is equal to the $\mathrm{Ti}-\mathrm{N}_{\mathrm{im}}$ distance of $1.810(1) \AA$ in Doxsee's ${ }^{42}$ very delocalized $\left\{\mathrm{Cp}_{2} \mathrm{Ti}\left(\mathrm{PMe}_{3}\right)\right\}_{2}\{\mu$-NC(Mes)C(Mes)N $\}$, which features the longest $\mathrm{Ti}-\mathrm{N}_{\mathrm{im}}$ bond reported to date. The $\mathrm{N}(1)-\mathrm{B}(1)$ distance of $1.3782(12) \AA$ is significantly shorter than in 23 or any transition metal borylimide reported herein or previously, and is comparable to the crystallographic $\mathrm{B}-\mathrm{NH}_{2}$ distance of 1.375(8) $\AA$ in $\mathrm{H}_{2} \mathrm{NBMes}_{2}$ (monomeric with trigonal planar boron). ${ }^{33}$ The $\mathrm{N}_{\mathrm{im}}-\mathrm{BMes}_{2}$ bond distances in the two previously structurally characterized examples of this type of borylimido ligand (namely, W(NMes) $)_{2}(\mathrm{NBMes})\left(\mathrm{PMe}_{3}\right)_{2}$ and $\left.\mathrm{W}\left(\mathrm{NBMes}_{2}\right)_{2} \mathrm{Cl}_{2}\left(\mathrm{PMe}_{3}\right)_{2}\right)$ were $1.39(1)$ and $1.43(1) \AA$, suggesting significantly more multiple $(\pi$-) bond character in the $\mathrm{N}_{\mathrm{im}}-\mathrm{B}$ bond of $26 .{ }^{12}$ There is no tendency in 26 toward ring-slippage of either $\mathrm{Cp}^{\prime \prime}$ ring, and the $\mathrm{Ti}(1)-\mathrm{C}$ distances lie in the relatively narrow range $2.364(1)-2.446(1) \AA$. The Ti$C \mathrm{p}_{\text {cent }}$ distances of $2.08 \AA$ in 26 are much shorter than those in 23 (av. $2.18 \pm 0.04 \AA$ ), and the $C \mathrm{p}_{\text {cent }(1)}-\mathrm{Ti}(1)-\mathrm{Cp}_{\text {cent }(2)}$ angle of $140^{\circ}$ is considerably larger than the value of $125.1^{\circ}$ in 23 .

Structural comparisons can also be made with $\mathrm{Cp}^{\prime \prime}{ }_{2} \mathrm{Ti}$ $\left(\mathrm{NSiMe}_{3}\right)$ and $\mathrm{Cp}^{*}{ }_{2} \mathrm{Ti}\left(\mathrm{NAr}^{\prime}\right)$, both of which are base-free like 26, and the former has the same cyclopentadienyl ligand substituents. The $\mathrm{Ti}-\mathrm{N}_{\mathrm{im}}$ distances are $1.722(4)$ and 1.763(1) $\AA$; the average $\mathrm{Ti}-\mathrm{Cp}_{\mathrm{cent}}$ distances are 2.15 and $2.12 \AA$; and the $\mathrm{Cp}_{\text {cent }}-\mathrm{Ti}-\mathrm{Cp}_{\text {cent }}$ angles are 128.3 and $135.3^{\circ}$, respectively. This seems to be consistent with the metric data for 26 and apparently implies that increasing $\pi$-accepting ability of the $\mathrm{N}_{\text {im }}$ substituent (anticipated to be $\mathrm{SiMe}_{3}<$ aryl $<\mathrm{BMes}_{2}$ ) drives these variations. The computational studies described below support this hypothesis.

Electronic Structure and Bonding in Bis(cyclopentadienyl)titanium Borylimido Compounds. As mentioned, bis(cyclopentadienyl) transition metal imides are interesting particularly from a bonding point of view, being socalled " $\pi$-loaded" complexes. ${ }^{3 \mathrm{~b}}$ These have more $\pi$-donor ligand orbitals than the metal has suitable acceptor orbitals of correct symmetry, resulting in one or more nonbonding ligand-based MOs. Early examples include tris(imido) $\mathrm{d}^{0}$ complexes of the type $C_{3 v}-\mathrm{M}(\mathrm{NR})_{3}(\mathrm{~L})$ and $\mathrm{D}_{3 h}-\mathrm{M}(\mathrm{NR})_{3} \cdot{ }^{3 \mathrm{a}, \mathrm{f}, 43}$ The new metallocene borylimides $\mathrm{Cp}_{2} \mathrm{Ti}\left\{\mathrm{NB}\left(\mathrm{NAr}{ }^{\prime} \mathrm{CH}\right)_{2}\right\}(\mathrm{py}) \quad(23)$ and $\mathrm{Cp}^{\prime \prime}{ }_{2} \mathrm{Ti}\left(\mathrm{NBMes}_{2}\right)$ (26) are isolobal ${ }^{44}$ analogues of these compounds.

At first sight 23 is a 20 valence electron compound, provided that the $\pi$-donor ligands are able to donate their maximum number of electrons (specifically $5 \mathrm{e}$ for $\mathrm{Cp}$ and $4 \mathrm{e}$ for the imide in the neutral electron-counting formalism ${ }^{45}$ ). Compound 26 appears to be an 18 valence electron compound, but previous theoretical, spectroscopic, and structural studies of a number of Groups 4-6 complexes of the type $\mathrm{Cp}^{\mathrm{R}}{ }_{2} \mathrm{M}(\mathrm{E})(\mathrm{L})(\mathrm{E}=\mathrm{O}$ or $N R ; L=2$ - or 1-electron donor or none $)^{3 h, 46}$ would suggest it should have a nonbonding, ligand-based MO. To gain a better understanding of the bonding in the new family of metallocene borylimides and metal-borylimide bonding in general we studied a small group of complexes $\mathrm{Cp}_{2} \mathrm{Ti}(\mathrm{NR})(\mathbf{2} \mathbf{R})$ (Figure 13) by DFT and QTAIM methods. Calculations were also carried out on pyridine adducts $\mathrm{Cp}_{2} \mathrm{Ti}(\mathrm{NR})(\mathrm{py})$. These gave analogous results but the analysis was less straightforward in the lower symmetry of these species.

The bonding in bent metallocenes $\mathrm{Cp}_{2} \mathrm{M}(\mathrm{L})$ is usually approached by considering the interactions of the frontier molecular orbitals (FMOs) of the ligands ' $L$ ' with those of a bent $\mathrm{Cp}_{2} \mathrm{M}$ moiety. The latter are well-known from previous studies. ${ }^{46,47}$ For comparison we calculated the FMOs of $\mathrm{d}^{0} C_{2 v^{-}}$ $\left[\mathrm{Cp}_{2} \mathrm{Ti}\right]^{2+}$ (Figure $\mathrm{S} 11$ ) at $\mathrm{Cp}_{\text {cent }}-\mathrm{Ti}-\mathrm{Cp}_{\text {cent }}$ angles of $128.5^{\circ}$ and $135.2^{\circ}$, these being the angles in the optimized geometries of $\mathrm{Cp}_{2} \mathrm{Ti}(\mathrm{NMe})(\mathbf{2 Q} \mathbf{M e})$ and $\mathrm{Cp}_{2} \mathrm{Ti}\left(\mathrm{NBMe}_{2}\right)\left(\mathbf{2} \mathbf{Q} \mathbf{B M e}_{2}\right)$. $\left[\mathrm{Cp}_{2} \mathrm{Ti}\right]^{2+}$ has three nonbonding, vacant FMOs, two of $\mathrm{a}_{1}(\sigma)$ and one of $b_{1}(\pi)$ symmetry (in contrast to $[\mathrm{CpTi}\{\mathrm{MeC}$ $\left.\left.(\mathrm{NMe})_{2}\right\}\right]^{2+}$ (Figure S12) which has four FMOs). It is the higher energy $2 \mathrm{a}_{1}$ FMO that interacts best with the $\sigma$-donor orbital of a ligand ' $\mathrm{L}$ ' approaching along the molecular $\mathrm{C}_{2}$ 

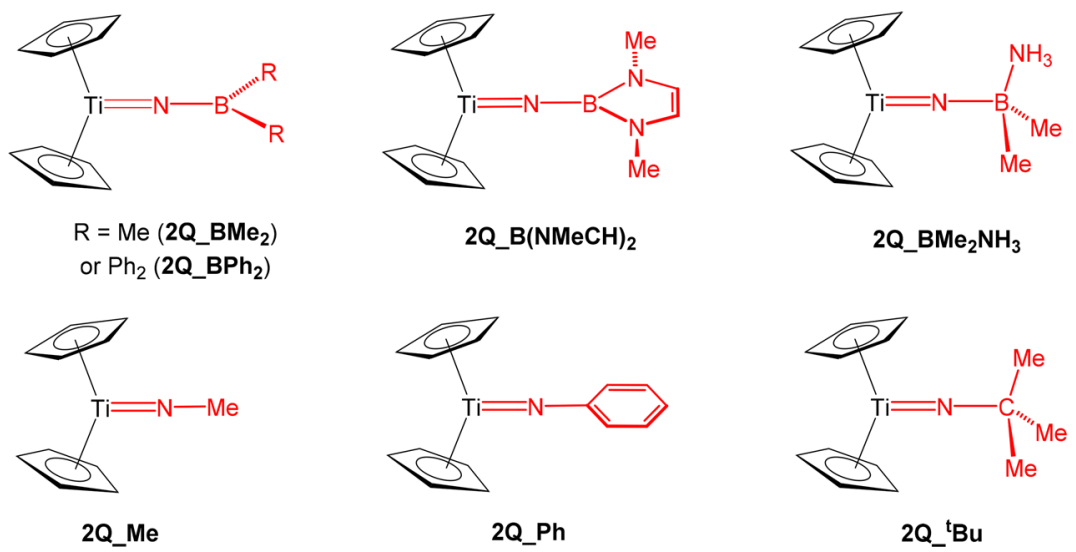

Figure 13. Model bis(cyclopentadienyl) complexes.

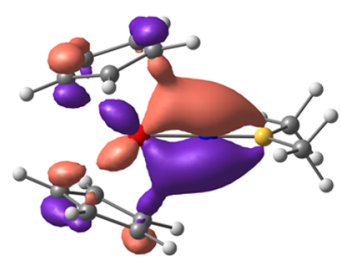

HOMO-5 $\left(\pi_{\mathrm{v}},-7.97 \mathrm{eV}\right)$

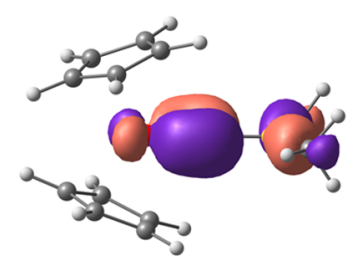

HOMO-1 $\left(\pi_{\mathrm{h}},-6.14 \mathrm{eV}\right)$

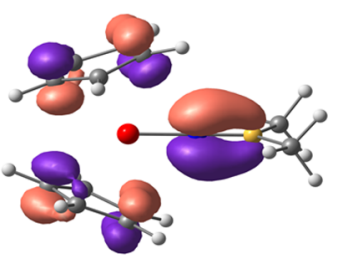

HOMO $\left(\pi_{\mathrm{nb}}-5.55 \mathrm{eV}\right)$

Figure 14. Selected molecular orbitals of $\mathrm{Cp}_{2} \mathrm{Ti}\left(\mathrm{NBMe}_{2}\right)\left(2 \mathrm{Q} \mathbf{B M e}_{2}\right)$ and their energies. Isosurfaces are drawn at the 0.063 au contour level. The LUMO is shown in Figure S13 of the Supporting Information.

axis; ${ }^{46 a, 47}$ the $2 b_{1}$ FMO lies in the horizontal mirror plane and can interact with $\pi_{\mathrm{h}}$ of an approaching $\mathrm{NBR}_{2}$ or other imido ligand (according to the geometry illustrated in Figure 13). $\left[\mathrm{Cp}_{2} \mathrm{Ti}\right]^{2+}$ has no vacant $\pi$-orbital of suitable symmetry (i.e., orientation) to interact with $\pi_{\mathrm{v}}$ of $\mathrm{NBR}_{2}$. However, it is known that an out-of-plane $\pi$-interaction can take place with the $\mathrm{LUMO}+3$ of $\mathrm{d}^{0} \quad \mathrm{Cp}_{2} \mathrm{M}\left(2 \mathrm{~b}_{2}\right.$ in Figure S11), sometimes described as the "fourth frontier orbital" of a bent metallocene. ${ }^{46 a}$ This is formally Cp-M $\pi^{*}$ antibonding and the counterpart of the Cp-M $\pi$-bonding HOMO $\left(1 b_{2}\right.$ in Figure S11). Hoffmann showed that decreasing the $\mathrm{Cp}_{\text {cent }}-\mathrm{Ti}-\mathrm{Cp}_{\text {cent }}$ angle of $\mathrm{Cp}_{2} \mathrm{M}$ stabilizes $2 \mathrm{~b}_{2}$ and destabilizes $1 \mathrm{~b}_{2}$. Therefore, strong $\pi_{\mathrm{h}}$-donation should favor a smaller angle to enhance interaction between the various FMOs involved in this interaction. ${ }^{47}$ In addition, formal $\pi_{\mathrm{v}}$-donation into $2 \mathrm{~b}_{2}$ should also lead to longer $\mathrm{M}-\mathrm{C} \mathrm{p}_{\text {cent }}$ distances ${ }^{46 \mathrm{a}}$ as is found for most metallocene-imido compounds. On the other hand, it was also found that $2 a_{1}$ and $2 b_{1}$ are destabilized with bending, ${ }^{47}$ and therefore good $\sigma$-and $\pi_{\mathrm{h}}$-donors are predicted to favor a larger $\mathrm{Cp}_{\text {cent }}-\mathrm{Ti}-\mathrm{Cp}_{\text {cent }}$ angle.

A molecular orbital analysis of $2 \mathbf{Q} \mathbf{R}$ found the bonding description expected from the results described above for $1 \mathbf{Q} \mathbf{R}$ and other studies of $\mathrm{Cp}_{2} \mathrm{M}(\mathrm{NR})$. Figure 14 shows the principal bonding and nonbonding $\pi$-type $\mathrm{Ti}-\mathrm{N}_{\mathrm{im}} \mathrm{MOs}$ of 2Q $\mathbf{B M e}_{2}$; Figure S13 of the Supporting Information illustrates the nonbonding LUMO which is based on the $2 \mathrm{a}_{1}$ FMO of $\left[\mathrm{Cp}_{2} \mathrm{Ti}\right]^{2+}$. The HOMO-1 of $\mathbf{2 Q} \mathbf{B M e}_{2}$ is the Ti- $\mathrm{N}_{\mathrm{im}} \pi_{\mathrm{h}}$ interaction. The corresponding $\pi_{\mathrm{v}}$ interaction is found in HOMO-5 which also contains significant $\mathrm{Cp}-\mathrm{Ti}$ bonding character. The HOMO $\left(\pi_{\mathrm{nb}}\right)$ of $\mathbf{2} \mathbf{Q} \mathbf{B M e} \mathbf{M}_{\mathbf{2}}$ is wholly ligandbased and $56 \% \mathrm{Cp}_{2}$ in character, the rest being contributions from $\mathrm{NBMe}_{2}$. The HOMO and HOMO-5 of $2 \mathbf{Q} \mathbf{B M e}_{2}$ arise from the three-center/four-electron-like interaction between the $\pi_{\mathrm{v}}$ donor of $\left[\mathrm{NBMe}_{2}\right]^{2-}$ and the $1 b_{2}$ (HOMO) and $2 b_{2}$
$(\mathrm{LUMO}+3)$ FMOs of $\left[\mathrm{Cp}_{2} \mathrm{Ti}\right]^{2+}$. The electronic structures of the other $2 \mathbf{Q} \mathbf{R}$ compounds resemble that of $2 \mathbf{Q} \mathbf{B M e}_{2}$ with different orbital mixing from the $\mathrm{N}_{\mathrm{im}} \mathrm{R}$-groups. There are no systematic trends in atomic contributions to $\pi_{\mathrm{nb}}$ from the $\mathrm{Cp}_{2}$ and NR fragments due to different degrees of R-group orbital mixing, and the small changes involved.

Table 3 lists the principal geometric and QTAIM data, and bond dissociation energies for $2 \mathbf{Q} \mathbf{R}$. The geometric parameters agree well with their experimental counterparts considering the rather different steric factors involved. The trends in $d\left(\mathrm{Ti}-\mathrm{N}_{\mathrm{im}}\right)$ with R-group follow closely those in $\mathrm{CpTi}\left\{\mathrm{MeC}(\mathrm{NMe})_{2}\right\}(\mathrm{NR})(\mathbf{1} \mathbf{R} \mathbf{R})$ being shortest for $\mathrm{R}=\mathrm{Me}$ or $\mathrm{B}(\mathrm{NMeCH})_{2}$ and longest for $\mathrm{R}=\mathrm{BMe}_{2}$ and $\mathrm{BPh}_{2}$. However, whereas $d\left(\mathrm{Ti}-\mathrm{N}_{\mathrm{im}}\right)$ for $\mathbf{1 Q} \mathrm{Me}$ and $2 \mathbf{Q}$ Me are very similar $(\Delta=0.002 \AA)$, the differences (av. $\Delta=0.03 \AA$ ) for $\mathbf{1 Q} \mathbf{B R}_{2}$ and $2 \mathbf{Q} \mathbf{B R}_{2}(\mathrm{R}=\mathrm{Me}$ or $\mathrm{Ph})$ are significantly larger. The $d\left(\mathrm{Ti}-\mathrm{N}_{\mathrm{im}}\right)$ and $d\left(\mathrm{Ti}-\mathrm{Cp}_{\text {cent }}\right)$ distances show a strong anticorrelation $\left(R^{2}=0.989\right)$, the longest $d\left(\mathrm{Ti}-\mathrm{Cp}_{\mathrm{cent}}\right)$ being found for the shortest $d\left(\mathrm{Ti}-\mathrm{N}_{\mathrm{im}}\right)$. The $\mathrm{Ti}-\mathrm{N}_{\mathrm{im}}$ distances and $\mathrm{C} \mathrm{p}_{\text {cent }}-\mathrm{Ti}-\mathrm{Cp}_{\text {cent }}$ angles directly correlate $\left(R^{2}=0.985\right)$ as illustrated in Figure 15a. This is clearly due to R-group electronic effects as shown by calculations on $2 Q \mathrm{Me}$ fxd (Table 3 and gray diamond point in Figure 15a). Here $d \overline{(T i-}$ $\mathrm{N}_{\text {im }}$ ) was set to $1.737 \AA$ (the same value as in $2 \mathbf{Q} \mathbf{B M e}_{2}$ ) and then fixed for an otherwise unconstrained geometry optimization. The resultant $d\left(\mathrm{Ti}-\mathrm{Cp}_{\text {cent }}\right)$ and $\mathrm{Cp}_{\text {cent }}-\mathrm{Ti}-\mathrm{Cp}_{\text {cent }}$ and QTAIM parameters changed very little from $2 \mathbf{Q}$ Me itself.

In contrast, adding $\mathrm{NH}_{3}$ to the $\pi$-accepting boron atom of $2 \mathrm{Q} \mathbf{B M e}_{2}$ to form $2 \mathrm{Q} \mathbf{B M e}_{2} \mathbf{N H}_{3}$ with a non- $\pi$-accepting boron atom led to decreased values for $d\left(\mathrm{Ti}-\mathrm{N}_{\mathrm{im}}\right)$ and $\mathrm{Cp}_{\text {cent }}-$ $\mathrm{Ti}-\mathrm{Cp}_{\text {cent }}$ and a longer $d\left(\mathrm{Ti}-\mathrm{Cp}_{\text {cent }}\right)$. The geometric features of the isosteric and isoelectronic $2 \mathbf{Q}{ }^{t} \mathbf{B u}$ were very similar to those of $2 \mathrm{Q} \mathrm{BMe}_{2} \mathrm{NH}_{3}$ implying an important role for the $\pi_{\mathrm{v}}$ $\mathrm{Ti}-\mathrm{N}_{\mathrm{im}} \mathrm{MO}$ of $2 \mathbf{Q} \mathbf{R}$ in setting the main geometric features. 


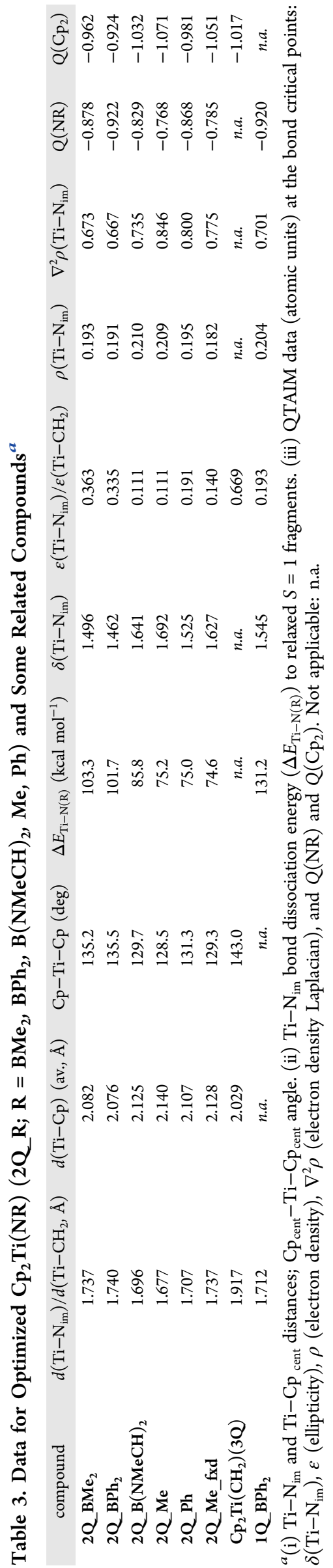

The push-pull or buffering effect between the Ti-Cp and $\mathrm{Ti}-$ $\mathrm{N}_{\text {im }}$ interactions is also confirmed by the strong anticorrelation $\left(R^{2}=0.978\right)$ between $Q\left(\mathrm{Cp}_{2}\right)$ vs $Q(\mathrm{NR})$ for $2 \mathbf{Q} \mathbf{R}$ in Figure $15 \mathrm{~b}$ (note that $Q(\mathrm{Ti})$ varies little throughout the series $2 \mathbf{Q} \mathbf{R}$, maintaining a value of ca. $+1.85 \pm 0.01$ ).

As a further test we calculated the geometry and QTAIM parameters of the hypothetical methylidene $\mathrm{Cp}_{2} \mathrm{Ti}\left(\mathrm{CH}_{2}\right)(3 \mathrm{Q})$ which forms only a $\mathrm{Ti}-\mathrm{CH}_{2} \sigma$-bond and a $\mathrm{Ti}-\mathrm{CH}_{2} \pi_{\mathrm{h}}$ bond, without any additional $\pi_{\mathrm{v}}$ interaction. The $\mathrm{Ti}-\mathrm{Cp}$ distance $(2.029 \AA)$ and $\mathrm{Cp}_{\text {cent }}-\mathrm{Ti}-\mathrm{Cp}_{\text {cent }}$ angle $\left(143.0^{\circ}\right)$ are again consistent with $\mathrm{Ti}-\mathrm{N}_{\mathrm{im}}$ bond $\pi_{\mathrm{v}}$ effects, rather than $\pi_{\mathrm{h}}$ or $\sigma$ effects, being the most important in setting the geometries of $\mathrm{Cp}_{2} \mathrm{Ti}(\mathrm{NR})$ and their real counterparts. Although a base-free titanium alkylidene analogous to $\mathbf{3 Q}$ has not been isolated and crystallographically characterized, we note that the $\mathrm{Cp}_{\text {cent }}-\mathrm{Ti}-$ $\mathrm{Cp}_{\text {cent }}$ angle of $143.2^{\circ}$ in the $\mathrm{d}^{2}$ compound $\mathrm{Cp}_{2} \mathrm{~W}(\mathrm{CHPh})^{48}$ is very similar to than in $3 Q$ while the corresponding angle in $\mathrm{d}^{2}$ $\mathrm{Cp}_{2} \mathrm{Mo}\left(\mathrm{N}^{\mathrm{t}} \mathrm{Bu}\right)^{46 \mathrm{c}}$ is $127.9^{\circ}$, very close to the $128.5^{\circ}$ value calculated for $2 \mathrm{Q} \mathrm{Me}$ and $2 \mathrm{Q}{ }^{\mathrm{t}} \mathrm{Bu}$.

The trends in the principal QTAIM parameters and bond dissociation energy with $\mathrm{N}_{\mathrm{im}}$ R-group type (Table 3) for $\mathbf{2} \mathbf{Q} \mathbf{R}$ parallel those found for $1 \mathbf{Q} \mathbf{R}$, with the Figure $15 \mathrm{c}$,d showing a strong correlation between the $\Delta E_{\mathrm{Ti}-\mathrm{N}(\mathrm{R})}$ values for $2 \mathbf{Q} \mathbf{R}$ and those for 1Q $\mathbf{R}\left(R^{2}=0.993\right)$, and an anticorrelation between $\Delta E_{\mathrm{Ti}-\mathrm{N}(\mathrm{R})}$ and $\nabla^{2} \rho\left(R^{2}=0.925\right)$. These relationships and the other QTAIM data for $2 \mathbf{Q} \mathbf{R}$ show that the underlying electronic factors controlling the bond energies in the metallocene systems are the same as in the cyclopentadienylamidinates $\mathbf{1 Q} \mathbf{R}$. Also as in the $1 \mathbf{Q} \mathbf{R}$ series, the $\mathrm{Ti}-\mathrm{N}_{\mathrm{im}}$ bond lengths in $2 \mathbf{Q} R$ are dominated by $\mathrm{Ti}-\mathrm{N}_{\mathrm{im}} \pi_{\mathrm{v}}$ bonding effects. The latter are further amplified by the $\pi$-loaded nature of these metallocene derivatives, giving disproportionately longer $\mathrm{Ti}-\mathrm{N}_{\mathrm{im}}$ bonds, smaller $\delta\left(\mathrm{Ti}-\mathrm{N}_{\mathrm{im}}\right)$ indices, and larger $\varepsilon$ values for the most $\pi$-accepting $\mathrm{BR}_{2}(\mathrm{R}=\mathrm{Me}, \mathrm{Ph})$.

\section{CONCLUSIONS}

In this contribution we have developed synthetic entry points to two classes of borylimido compounds, namely, those based on N,N-substituted boryl substituents ((L)Ti\{NB$\left.\left(\mathrm{NAr}^{\prime} \mathrm{CH}\right)_{2}\right\}$ ) and one with a diarylboryl substituent (i.e., $\left.\mathrm{Cp}_{2}{ }_{2} \mathrm{Ti}\left(\mathrm{NBMes}_{2}\right)(26)\right)$. For the former type it was possible to use either a double-deprotonation strategy starting from $\mathrm{Ti}\left(\mathrm{NMe}_{2}\right)_{2} \mathrm{Cl}_{2}$ or endergonic borylamine-tert-butylimide exchange, provided that the latter was driven in favor of the product. Neither of these protocols is thermodynamically feasible for dialkyl- or diarylborylamines. However, oxidative methods seem to be suitable for appropriate precursors, for example, reaction of $\left(\mathrm{Cp}^{\prime \prime}{ }_{2} \mathrm{Ti}\right)_{2}\left(\mu_{2}: \eta^{1}, \eta^{1}-\mathrm{N}_{2}\right)$ with $\mathrm{N}_{3} \mathrm{BMes}_{2}$ to form 26. The three synthetic methods gave access to sandwich or half-sandwich borylimido compounds, as well as the useful synthons $\mathrm{Ti}\left\{\mathrm{NB}\left(\mathrm{NAr}{ }^{\prime} \mathrm{CH}\right)_{2}\right\} \mathrm{Cl}_{2}\left(\mathrm{NHMe}_{2}\right)_{2}$ and $\mathrm{Ti}\{\mathrm{NB}-$ $\left.\left(\mathrm{NAr}^{\prime} \mathrm{CH}\right)_{2}\right\} \mathrm{Cl}_{2}(\mathrm{py})_{3}$.

With specific regard to the protonolysis methods, the main limitation is the strong $\mathrm{H}-\mathrm{N}$ bonds of the borylamines compared to the bond strengths of the product imide. Other routes for imido groups from amines are, in principle, available: for example, alkane elimination from alkyl-amide precursors of the type $(\mathrm{L}) \mathrm{M}\left\{\mathrm{N}(\mathrm{H}) \mathrm{BR}_{2}\right\} \mathrm{R}^{\prime}$ as previously demonstrated for Group 4 organoimido compounds. ${ }^{1 \mathrm{~b}, \mathrm{f}, 15,49}$ An exploration of these routes was beyond the scope of our current study.

The QTAIM and NBO studies showed that two key descriptors of the metal-nitrogen multiple bond in imido and hydrazido compounds, namely, the bond distance and the 
(a)

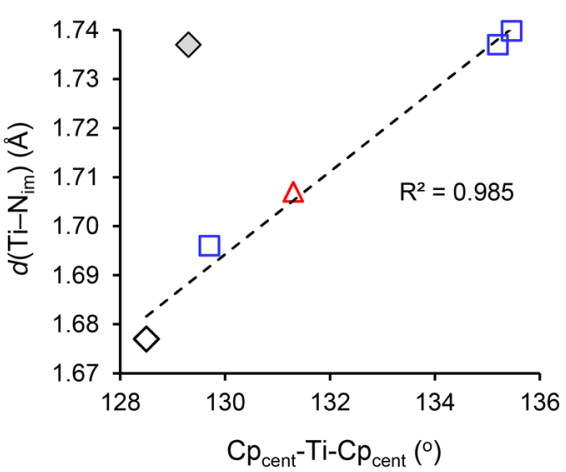

(c)

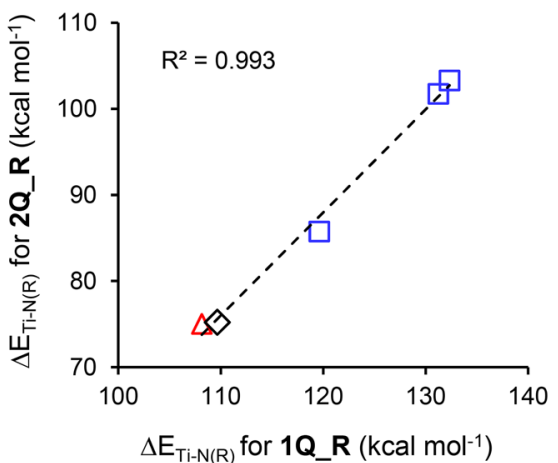

(b)

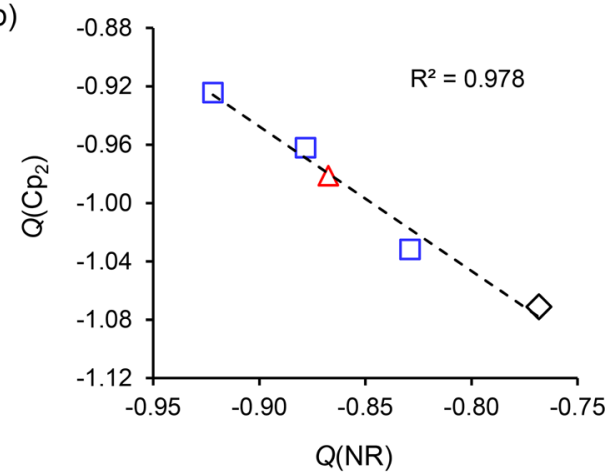

(d)

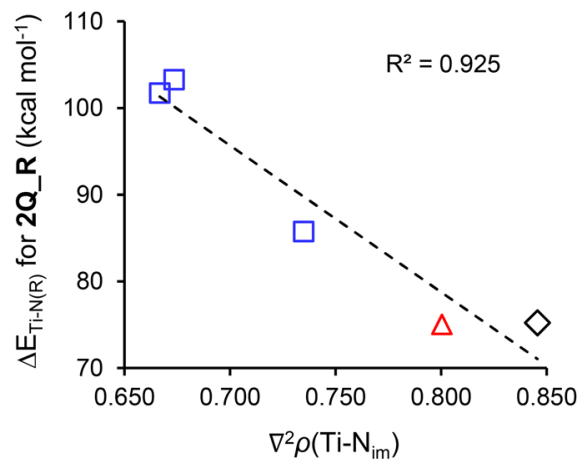

Figure 15. (a) Plot of $d\left(\mathrm{Ti}-\mathrm{N}_{\mathrm{im}}\right)$ vs. $\mathrm{Cp}_{\mathrm{cent}}-\mathrm{Ti}-\mathrm{Cp}_{\text {cent }}$ for $2 \mathrm{Q} \mathbf{R}$; the filled black diamond (not included in the linear regression) is for $2 \mathbf{Q} \mathbf{M e}$ fxd $\left(\mathrm{Ti}-\mathrm{N}_{\mathrm{im}}=1.737 \AA\right)$. (b) Plot of $Q\left(\mathrm{Cp}_{2}\right)$ vs $\mathrm{Q}(\mathrm{NR})$ for $2 \mathbf{Q} \mathbf{R}$. Plots of $\Delta E_{\mathrm{Ti}-\mathrm{N}(\mathrm{R})}$ for $\mathrm{Cp}_{2} \mathrm{Ti}(\mathrm{NR})$ (2Q $\left.\mathbf{R}\right)$ vs (c) $\Delta E_{\mathrm{Ti}-\mathrm{N}(\mathrm{R}) \text { for }}$ $\mathrm{CpTi}\left\{\mathrm{MeC}(\mathrm{NMe})_{2}\right\}(\mathrm{NR})(\mathbf{1 Q} \mathbf{R})$ and (d) $\nabla^{2} \rho$ (electron density Laplacian) for $\mathbf{2} \mathbf{Q} \mathbf{R}$. Key for all plots: blue $s q u a r e s, \mathrm{R}=\mathrm{BMe}_{2}, \mathrm{BPh}_{2}$, $\mathrm{B}(\mathrm{NMeCH})_{2}$; open black diamond, $\mathrm{R}=\mathrm{Me}$; red triangle, $\mathrm{R}=\mathrm{Ph}$.

bond dissociation energy, are separable and arise from distinct electronic factors. The variation in the $\mathrm{Ti}-\mathrm{N}_{\mathrm{im}}$ bond distance is found to be dominated by $\pi$ interactions with the substituent at the $\mathrm{N}_{\mathrm{im}}$ atom, while variation in the bond dissociation energy is found to arise primarily from the underlying $\sigma$-donor and $\pi_{\mathrm{h}}$ donor ability of the NR fragment, which in turn relates to the electronegativity of the $\mathrm{R}$ substituent. It is the latter effect which controls the favorability or otherwise of imide-amine exchange reactions, and the difficulties in forming borylimides through this methodology are found to arise from the high N$\mathrm{H}$ bond strengths in the corresponding borylamines, even though the $\mathrm{Ti}-\mathrm{N}_{\mathrm{im}}$ bonds of borylimides are the strongest of all the types of titanium imido compound $(\mathrm{L}) \mathrm{Ti}(\mathrm{NR})(\mathrm{R}=$ hydrocarbyl or $\mathrm{NR}_{2}^{\prime}$ ).

\section{EXPERIMENTAL SECTION}

Representative syntheses and characterizing data (noncyclopentadien$\mathrm{yl}$, half-sandwich and metallocene) are given below. General experimental procedures, details of starting materials, and syntheses and characterization of all the other new compounds are given in the Supporting Information.

Ti\{NB(NAr'CH) $\left.)_{2}\right\} \mathrm{Cl}_{2}\left(\mathrm{NHMe}_{2}\right)_{2}$ (8). To a solution of $\mathrm{Ti}\left(\mathrm{NMe}_{2}\right)_{2} \mathrm{Cl}_{2}$ $(1.36 \mathrm{~g}, 6.58 \mathrm{mmol})$ in toluene $(10 \mathrm{~mL})$ was slowly added a solution of $\mathrm{H}_{2} \mathrm{NB}\left(\mathrm{NAr}^{\prime} \mathrm{CH}\right)_{2}(6,2.52 \mathrm{~g}, 6.25 \mathrm{mmol})$ in toluene $(10 \mathrm{~mL})$, at $-78{ }^{\circ} \mathrm{C}$. The mixture was allowed to warm to room temperature, upon which it became a red/brown slurry. After stirring for $30 \mathrm{~min}$, all solids had dissolved, leaving a deep red solution, which was stirred at room temperature for a further $2.5 \mathrm{~h}$. The volatiles were then removed under reduced pressure to leave a red-brown, waxy solid. The product was triturated in hexane, yielding $\mathbf{8}$ as an orange-brown powder. Yield: 3.01 g (79\%). Diffraction-quality crystals were grown from a saturated hexane solution at room temperature. ${ }^{1} \mathrm{H}$ NMR $\left(\mathrm{C}_{6} \mathrm{D}_{6}, 400.1 \mathrm{MHz}\right): \delta$ $7.13\left(6 \mathrm{H}\right.$, overlapping $2 \times \mathrm{m}, m$ - and $\left.p-\mathrm{C}_{6} \underline{\mathrm{H}}_{3}{ }^{\mathrm{i}} \mathrm{Pr}_{2}\right), 5.73(2 \mathrm{H}, \mathrm{s}$, $\mathrm{NCH}), 3.53\left(4 \mathrm{H}\right.$, sept., $\left.{ }^{3} J=6.9 \mathrm{~Hz}, \mathrm{CHMeMe}\right), 2.67$ (2 H, sept., ${ }^{3} J=$

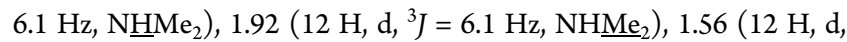
$\left.{ }^{3} J=6.9 \mathrm{~Hz}, \mathrm{CHMeMe}\right), 1.24\left(12 \mathrm{H}, \mathrm{d},{ }^{3} \mathrm{~J}=6.9 \mathrm{~Hz}, \mathrm{CHMeMe}\right) \mathrm{ppm}$. ${ }^{13} \mathrm{C}\left\{{ }^{1} \mathrm{H}\right\}$ NMR $\left(\mathrm{C}_{6} \mathrm{D}_{6}, 100.6 \mathrm{MHz}\right): \delta 146.8\left(i-\underline{\mathrm{C}}_{6} \mathrm{H}_{3}{ }^{\mathrm{i}} \mathrm{Pr}_{2}\right), 140.2(o-$ $\left.\underline{\mathrm{C}}_{6} \mathrm{H}_{3}{ }^{\mathrm{i}} \mathrm{Pr}_{2}\right), 127.2\left(p-\underline{\mathrm{C}}_{6} \mathrm{H}_{3}{ }^{\mathrm{i}} \mathrm{Pr}_{2}\right), 123.3\left(m-\underline{\mathrm{C}}_{6} \mathrm{H}_{3}{ }^{\mathrm{i}} \mathrm{Pr}_{2}\right), 115.5(\mathrm{NCH})$, $40.0\left(\mathrm{NHMe}_{2}\right), 28.4$ ( $\left.\mathrm{CHMeMe}\right), 24.2$ (CHMeMe), 24.0 (CHMeMe) ppm. ${ }^{11} \mathrm{~B}\left\{{ }^{1} \mathrm{H}\right\}$ NMR $\left(\mathrm{C}_{6} \mathrm{D}_{6}, 128.4 \mathrm{MHz}\right): \delta 14.2 \mathrm{ppm}$. IR $(\mathrm{NaCl}$ plates, Nujol mull, $\left.\mathrm{cm}^{-1}\right): 3289$ (w, nonbridging $\mathrm{N}-\mathrm{H}$ ), 3277 (w, hydrogen bonded $\mathrm{N}-\mathrm{H}), 1586(\mathrm{~m}), 1260(\mathrm{w}), 1180(\mathrm{w}), 1076(\mathrm{w})$, $1025(\mathrm{~m}), 983(\mathrm{~m}), 890(\mathrm{~m}), 798(\mathrm{~m}), 686(\mathrm{w}), 652(\mathrm{~m})$. IR (NaCl cell, $\left.\mathrm{CH}_{2} \mathrm{Cl}_{2}, \nu(\mathrm{N}-\mathrm{H}), \mathrm{cm}^{-1}\right)$ : 3288. Anal. found (calcd. for $\left.\mathrm{C}_{30} \mathrm{H}_{50} \mathrm{BCl}_{2} \mathrm{~N}_{5} \mathrm{Ti}\right)$ : C, 58.95 (59.04); $\mathrm{H}, 8.18$ (8.26); N, 11.37 (11.47)\%.

$\mathrm{Cp} * \mathrm{Ti}\left\{\mathrm{NB}\left(\mathrm{NAr}^{\prime} \mathrm{CH}\right)_{2}\right\} \mathrm{Cl}(\mathrm{py})$ (15). To a Schlenk flask were added $\mathrm{Cp} * \mathrm{Ti}\left(\mathrm{N}^{\mathrm{t}} \mathrm{Bu}\right) \mathrm{Cl}(\mathrm{py})(\mathbf{1 4}, 2.00 \mathrm{~g}, 5.42 \mathrm{mmol})$ and $\mathrm{H}_{2} \mathrm{NB}\left(\mathrm{NAr}^{\prime} \mathrm{CH}\right)_{2}$ $(6,1.97 \mathrm{~g}, 4.88 \mathrm{mmol})$. The two solids were heated with stirring to 140 ${ }^{\circ} \mathrm{C}$, at which temperature they melted to form a dark brown oil. Repeated, brief exposures to a dynamic vacuum resulted in bubbling of the oil as $\mathrm{H}_{2} \mathrm{~N}^{t} \mathrm{Bu}$ was released; the cessation of bubbling and no further diminishment of the vacuum (as measured by a Pirani gauge) indicated reaction completion. The oil was allowed to cool to room temperature, forming a deep red glassy solid, which was triturated in hexane $(10 \mathrm{~mL})$ to yield 15 as a red powder, before washing with further hexane $(2 \times 10 \mathrm{~mL})$ and drying in vacuo. Yield: $2.02 \mathrm{~g}(59 \%)$. Diffraction-quality crystals were grown from a saturated benzene/ hexane solution at room temperature. ${ }^{1} \mathrm{H}$ NMR $\left(\mathrm{C}_{6} \mathrm{D}_{6}, 400.1 \mathrm{MHz}\right): \delta$ $7.88\left(2 \mathrm{H}, \mathrm{d},{ }^{3} \mathrm{~J}=4.7 \mathrm{~Hz}, 2,6-\mathrm{py}\right), 7.25\left(2 \mathrm{H}, \mathrm{dd},{ }^{3} \mathrm{~J}=7.8 \mathrm{~Hz},{ }^{4} \mathrm{~J}=1.5\right.$ $\mathrm{Hz}, m-\mathrm{C}_{6} \underline{\mathrm{H}}_{3}{ }^{\mathrm{i}} \mathrm{Pr}_{2}$ closest to py), 7.17-7.12 $(2 \mathrm{H}, \mathrm{m}$ overlapping with residual protio solvent resonance, $\left.p-\mathrm{C}_{6} \underline{\mathrm{H}}_{3}{ }^{i} \mathrm{Pr}_{2}\right), 7.00\left(2 \mathrm{H}\right.$, dd, ${ }^{3} J=7.8$ $\mathrm{Hz},{ }^{4} \mathrm{~J}=1.5 \mathrm{~Hz}, m-\mathrm{C}_{6} \underline{\mathrm{H}}_{3}{ }^{\mathrm{i}} \mathrm{Pr}_{2}$ closest to $\left.\mathrm{Cl}\right), 6.65\left(1 \mathrm{H}, \mathrm{t},{ }^{3} \mathrm{~J}=7.8 \mathrm{~Hz}, 4-\right.$ py), $6.22\left(2 \mathrm{H}, \mathrm{m}, 3,5\right.$-py), $5.87(2 \mathrm{H}, \mathrm{s}, \mathrm{NCH}), 3.92\left(2 \mathrm{H}\right.$, sept., ${ }^{3} \mathrm{~J}=$ $6.9 \mathrm{~Hz}, \mathrm{CHMeMe}$ closest to py), $3.67\left(2 \mathrm{H}\right.$, sept., ${ }^{3} \mathrm{~J}=6.9 \mathrm{~Hz}$, ChMeMe closest to $\mathrm{Cl}), 1.71\left(15 \mathrm{H}, \mathrm{s}, \mathrm{C}_{5} \mathrm{Me}_{5}\right), 1.61\left(6 \mathrm{H}, \mathrm{d},{ }^{3} \mathrm{~J}=6.8\right.$ $\mathrm{Hz}, \mathrm{CHMeMe}$ closest to py), $1.31\left(12 \mathrm{H}\right.$, app. t, app. ${ }^{3} \mathrm{~J}=7.3 \mathrm{~Hz}$, overlapping CHMeMe closest to py and $\mathrm{CHMeMe}$ closest to $\mathrm{Cl}$ ), 1.26 $\left(6 \mathrm{H}, \mathrm{d},{ }^{3} \mathrm{~J}=6.8 \mathrm{~Hz}, \mathrm{CHMeMe}\right.$ closest to $\left.\mathrm{Cl}\right) \mathrm{ppm} .{ }^{13} \mathrm{C}\left\{{ }^{1} \mathrm{H}\right\} \mathrm{NMR}$ 
$\left(\mathrm{C}_{6} \mathrm{D}_{6}, 100.6 \mathrm{MHz}\right): \delta 150.4$ (2,6-py), $147.3\left(o-\underline{\mathrm{C}}_{6} \mathrm{H}_{3}{ }^{\mathrm{i}} \mathrm{Pr}_{2}\right.$ closest to $\mathrm{Cl}), 147.0\left(o-\underline{C}_{6} \mathrm{H}_{3}{ }^{i} \mathrm{Pr}_{2}\right.$ closest to py), $141.9\left(i-\underline{C}_{6} \mathrm{H}_{3}{ }^{\mathrm{i}} \mathrm{Pr}_{2}\right), 126.9$ (p$\left.\mathrm{C}_{6} \mathrm{H}_{3}{ }^{\mathrm{i}} \mathrm{Pr}_{2}\right), 123.8$ (3,5-py), 123.8 ( $m-\underline{\mathrm{C}}_{6} \mathrm{H}_{3}{ }^{\mathrm{i}} \mathrm{Pr}_{2}$ closest to $\left.\mathrm{Cl}\right), 123.1$ ( $m$ $\underline{\mathrm{C}}_{6} \mathrm{H}_{3}{ }^{\mathrm{i}} \mathrm{Pr}_{2}$ closest to py), $121.8\left(\underline{\mathrm{C}}_{5} \mathrm{Me}_{5}\right), 116.9(\mathrm{NCH}), 29.0$ ( CHMeMe closest to py), 28.4 ( (CHMeMe closest to $\mathrm{Cl}$ ), 24.9 (CHMeMe closest to py), 24.2 (CHMeMe closest to $\mathrm{Cl}$ ), 23.6 (CHMeMe closest to py), 12.0 $\left(\mathrm{C}_{5} \overline{\mathrm{Me}_{5}}\right)$ ppm. ${ }^{11} \mathrm{~B}\left\{{ }^{1} \mathrm{H}\right\}$ NMR $\left(\mathrm{C}_{6} \mathrm{D}_{6}, 128.4 \mathrm{MHz}\right): \delta 15.5 \mathrm{ppm}$. IR (NaCl plates, Nujol mull, $\left.\mathrm{cm}^{-1}\right): 3583(\mathrm{w}), 3064(\mathrm{~m}), 2724(\mathrm{~m}), 1936$ $(\mathrm{w}), 1868(\mathrm{w}), 1801(\mathrm{w}), 1663(\mathrm{~m}), 1606(\mathrm{~s}), 1585(\mathrm{w}), 1328(\mathrm{~m})$, $1308(\mathrm{w}), 1275(\mathrm{~m}), 1215(\mathrm{~m}), 1178(\mathrm{w}), 1154(\mathrm{~m}), 1114(\mathrm{~m}), 1070$ (m), $1046(\mathrm{~m}), 1017(\mathrm{w}), 1009(\mathrm{w}), 894(\mathrm{~m}), 883(\mathrm{w}), 803(\mathrm{~m}), 763$ (m), $755(\mathrm{~m}), 721(\mathrm{w}), 681(\mathrm{w}), 651(\mathrm{~s})$. EI-MS: $m / z=698[\mathrm{M}]^{+}$ (1\%). Anal. found (calcd. for $\mathrm{C}_{41} \mathrm{H}_{56} \mathrm{BClN}{ }_{4} \mathrm{Ti}$ ): C, 70.35 (70.45); $\mathrm{H}$, 7.95 (8.07); N, 7.95 (8.01)\%.

$\mathrm{Cp}_{2} \mathrm{Ti}\left\{\mathrm{NB}\left(\mathrm{NAr}^{\prime} \mathrm{CH}\right)_{2}\right\}$ (py) (23). To a Schlenk flask containing $\mathrm{Ti}\left\{\mathrm{NB}\left(\mathrm{NAr}{ }^{\prime} \mathrm{CH}\right)_{2}\right\} \mathrm{Cl}_{2}(\mathrm{py})_{3}(\mathbf{9}, 0.500 \mathrm{~g}, 0.660 \mathrm{mmol})$ and $\mathrm{NaCp}$ $(0.122 \mathrm{~g}, 1.39 \mathrm{mmol})$ was added toluene $(10 \mathrm{~mL})$ at $-78{ }^{\circ} \mathrm{C}$. The mixture was allowed to warm to room temperature, and then stirred for $3 \mathrm{~h}$, after which it had become a deep brown suspension. The volatiles were removed under reduced pressure, and the product extracted into pentane $(4 \times 10 \mathrm{~mL})$. The combined extracts were evaporated to dryness, giving 23 as an orange powder. Yield: $0.253 \mathrm{~g}$ (58\%). Diffraction-quality crystals were grown from a concentrated pentane solution at $5{ }^{\circ} \mathrm{C} .{ }^{1} \mathrm{H}$ NMR $\left(\mathrm{C}_{6} \mathrm{D}_{6}, 400.1 \mathrm{MHz}\right): \delta 7.96(2 \mathrm{H}$, d, $\left.{ }^{3} J=4.9 \mathrm{~Hz}, 2,6-p y\right), 7.31-7.25(6 \mathrm{H}$, overlapping $2 \times \mathrm{m}, m$ - and $p$ $\left.\mathrm{C}_{6} \underline{\mathrm{H}}_{3}{ }^{\mathrm{i}} \operatorname{Pr}_{2}\right), 6.71\left(1 \mathrm{H}, \mathrm{t},{ }^{3} \mathrm{~J}=7.7 \mathrm{~Hz}, 4-\mathrm{py}\right), 6.23$ (2 H, m, 3,5-py), 5.94 $(2 \mathrm{H}, \mathrm{s}, \mathrm{NCH}), 5.69\left(10 \mathrm{H}, \mathrm{s}, \mathrm{C}_{5} \mathrm{H}_{5}\right), 3.74\left(4 \mathrm{H}\right.$, sept., ${ }^{3} \mathrm{~J}=6.9 \mathrm{~Hz}$, C $\underline{H M e M e}), 1.49\left(12 \mathrm{H}, \mathrm{d},{ }^{3} \mathrm{~J}=6.9 \mathrm{~Hz}, \mathrm{CHMeMe}\right), 1.30\left(12 \mathrm{H}, \mathrm{d},{ }^{3} \mathrm{~J}=\right.$ $6.9 \mathrm{~Hz}, \mathrm{CHMeMe}) \mathrm{ppm} .{ }^{13} \mathrm{C}\left\{{ }^{1} \mathrm{H}\right\} \mathrm{NMR}\left(\overline{\mathrm{C}}_{6} \mathrm{D}_{6}, 100.6 \mathrm{MHz}\right): \delta 155.1$ (2,6-py), $147.5\left(o-\underline{\mathrm{C}}_{6} \mathrm{H}_{3}{ }^{\mathrm{i}} \mathrm{Pr}_{2}\right), 142.2\left({ }^{i}-\underline{\mathrm{C}}_{6} \mathrm{H}_{3}{ }^{\mathrm{i}} \mathrm{Pr}_{2}\right), 136.4$ (4-py), 127.0 $\left(m-\underline{C}_{6} \mathrm{H}_{3}{ }^{\mathrm{i}} \mathrm{Pr}_{2}\right), 123.7\left(p-\underline{\mathrm{C}}_{6} \mathrm{H}_{3}{ }^{\mathrm{i}} \mathrm{Pr}_{2}\right), 123.6$ (3,5-py), $117.2(\mathrm{NCH})$, $111.4\left(\mathrm{C}_{5} \mathrm{H}_{5}\right), 28.9$ (ㄷMㄹe), 25.7 (CHMeMe), 23.6 (CHMeMe) ppm. ${ }^{11} \mathrm{~B}\left\{{ }^{1} \mathrm{H}\right\}$ NMR $\left(\mathrm{C}_{6} \mathrm{D}_{6}, 128.4 \mathrm{MHz}\right): \delta 18.0 \mathrm{ppm}$. IR $(\mathrm{NaCl}$ plates, Nujol mull, $\left.\mathrm{cm}^{-1}\right): 1602(\mathrm{~m}), 1583(\mathrm{w}), 1543(\mathrm{~m}), 1403(\mathrm{w})$, $1215(\mathrm{~m}), 1178(\mathrm{w}), 1068(\mathrm{~m}), 1023(\mathrm{~m}), 936(\mathrm{w}), 883(\mathrm{w}), 863(\mathrm{~s})$, $763(\mathrm{w}), 699(\mathrm{~m}), 668(\mathrm{~m}), 653(\mathrm{w})$. EI-MS: $m / z=580[\mathrm{M}-\mathrm{py}]^{+}$ (4\%). Anal. found (calcd. for $\left.\mathrm{C}_{41} \mathrm{H}_{51} \mathrm{BN}_{4} \mathrm{Ti}\right)$ : C, 74.61 (74.78); $\mathrm{H}, 7.96$ (7.81); N, $8.64(8.51) \%$.

\section{ASSOCIATED CONTENT}

\section{S Supporting Information}

The Supporting Information is available free of charge on the ACS Publications website at DOI: 10.1021/acs.inorgchem.7b01831.

Details of starting materials. Remaining details of the synthesis and characterizing data for new compounds. Computational details and total SCF and other energies for DFT computed structures (PDF)

Computed Cartesian coordinates of all of the molecules reported in this study. The file may be opened as a text file to read the coordinates, or opened directly by a molecular modeling program such as Mercury (version 3.3 or later, http://www.ccdc.cam.ac.uk/pages/Home. aspx) for visualization and analysis (XYZ)

\section{Accession Codes}

CCDC 1555531-1555541 contain the supplementary crystallographic data for this paper. These data can be obtained free of charge via www.ccdc.cam.ac.uk/data_request/cif, or by emailing data_request@ccdc.cam.ac.uk, or by contacting The Cambridge Crystallographic Data Centre, 12 Union Road, Cambridge CB2 1EZ, UK; fax: +44 1223336033.

\section{AUTHOR INFORMATION}

\section{Corresponding Authors}

*(E.C.) E-mail: eric.clot@umontpellier.fr.
*(P.M.) E-mail: philip.mountford@chem.ox.ac.uk. ORCID $\odot$

Eric Clot: 0000-0001-8332-5545

Philip Mountford: 0000-0001-9869-9902

Notes

The authors declare no competing financial interest.

\section{ACKNOWLEDGMENTS}

This work was funded by the EPSRC (Grant Reference EP/ L505031/1), the University of Oxford Clarendon Fund and the University of Oxford SCG Innovation Fund. We thank the University of Oxford's Advanced Research Computing facility for access to supercomputer and other resources. The authors declare no competing financial interests.

\section{REFERENCES}

(1) (a) Wigley, D. E. Organoimido complexes of the transition metals. Prog. Inorg. Chem. 1994, 42, 239-482. (b) Duncan, A. P.; Bergman, R. G. Selective Transformations of Organic Compounds by Imidozirconocene Complexes. Chem. Rec. 2002, 2, 431-445. (c) Mountford, P. New titanium imido chemistry. Chem. Commun. 1997, 2127-2134. (d) Gade, L. H.; Mountford, P. New transition metal imido chemistry with diamido-donor ligands. Coord. Chem. Rev. 2001, 216-217, 65-97. (e) Hazari, N.; Mountford, P. Reactions and applications of titanium imido compounds. Acc. Chem. Res. 2005, 38, 839-849. (f) Fout, A. R.; Kilgore, U. J.; Mindiola, D. J. The Progression of Synthetic Strategies to Assemble Titanium Complexes Bearing the Terminal Imide Group. Chem. - Eur. J. 2007, 13, 94289440.

(2) (a) Walsh, P. J.; Hollander, F. J.; Bergman, R. G. Generation, alkyne cycloaddition, $\mathrm{C}-\mathrm{H}$ activation, $\mathrm{N}-\mathrm{H}$ activation and dative ligand trapping reactions of the first monomeric imidozirconocene complexes. J. Am. Chem. Soc. 1988, 110, 8729-8731. (b) Hill, J. E.; Profilet, R. D.; Fanwick, P. E.; Rothwell, I. P. Synthesis, structure and reactivity of aryloxo(imido)titanium complexes. Angew. Chem., Int. Ed. Engl. 1990, 29, 664-665. (c) Roesky, H. W.; Voelker, H.; Witt, M.; Noltemeyer, M. Synthesis and Structure of $\mathrm{Ph}_{2} \mathrm{P}(\mathrm{S}) \mathrm{N}=\mathrm{TiCl}_{2} \cdot 3$ py, the first imidotitanium complex. Angew. Chem., Int. Ed. Engl. 1990, 29, 669-670. (d) Cummins, C. C.; Baxter, S. M.; Wolczanski, P. T. Methane and benzene $\mathrm{C}-\mathrm{H}$ activation via transient $\left({ }^{\mathrm{t}} \mathrm{Bu}_{3} \mathrm{SiNH}\right)_{2} \mathrm{Zr}(=$ $\left.\mathrm{NSi}^{\mathrm{t}} \mathrm{Bu}_{3}\right)$. J. Am. Chem. Soc. 1988, 110, 8731-8733.

(3) (a) Cundari, T. R. Transition metal imido complexes. J. Am. Chem. Soc. 1992, 114, 7879-7888. (b) Lin, Z.; Hall, M. B. A group theoretical analysis on transition metal complexes with metal-ligand multiple bonds. Coord. Chem. Rev. 1993, 123, 149-167. (c) Mountford, P.; Swallow, D. A direct relationship between $\mathrm{E}=\mathrm{T}$-L bond angle and $\mathrm{E}=\mathrm{Ti}$ bond length can exist in $\left[\mathrm{Ti}(\mathrm{E}) \mathrm{L}_{4}\right]$ complexes $(\mathrm{E}=$ organoimido or oxo). J. Chem. Soc., Chem. Commun. 1995, 2357-2359. (d) Kaltsoyannis, N.; Mountford, P. Theoretical study of the geometric and electronic structures of pseudo-octahedral $\mathrm{d}^{0}$ imido compounds of titanium: the trans influence in mer-[Ti(NR)$\left.\mathrm{Cl}_{2}\left(\mathrm{NH}_{3}\right)_{3}\right]\left(\mathrm{R}=\mathrm{Bu}^{\mathrm{t}}, \mathrm{C}_{6} \mathrm{H}_{5}\right.$ or $\left.\mathrm{C}_{6} \mathrm{H}_{4} \mathrm{NO}_{2}-4\right)$. J. Chem. Soc., Dalton Trans. 1999, 781-789. (e) Cundari, T. R. Computational Studies of Transition Metal - Main Group Multiple Bonding. Chem. Rev. 2000, 100, 807-818. (f) Schwarz, A. D.; Nielson, A. J.; Kaltsoyannis, N.; Mountford, P. The first group 4 metal bis(imido) and tris(imido) complexes. Chem. Sci. 2012, 3, 819-824. (g) Blake, A. J.; Dunn, S. C.; Green, J. C.; Jones, N. M.; Moody, A. G.; Mountford, P.; Dunn, S. C. Synthesis and Molecular and Electronic Structure of Monomeric $\left[\mathrm{Ti}\left(\eta-\mathrm{C}_{8} \mathrm{H}_{8}\right)\left(\mathrm{N}^{\mathrm{t}} \mathrm{Bu}\right)\right]$. Chem. Commun. 1998, 1235-1236. (h) Selby, J. D.; Feliz, M.; Schwarz, A. D.; Clot, E.; Mountford, P. New Sandwich and Half-Sandwich Titanium Hydrazido Compounds. Organometallics 2011, 30, 2295-2307. (i) Boyd, C. L.; Clot, E.; Guiducci, A. E.; Mountford, P. Pendant arm functionalised benzamidinate titanium imido compounds: experimental and computational studies of their reactions with $\mathrm{CO}_{2}$. Organometallics 2005, 24, 2347-2367. 
(4) (a) Mindiola, D. J. Early Transition-Metal Hydrazido Complexes: Masked Metallanitrenes from N-N Bond Scission. Angew. Chem., Int. Ed. 2008, 47, 1557-1559. (b) Walsh, P. J.; Carney, M. J.; Bergman, R. G. Generation, Dative Ligand trapping and N-N bond cleavage reactions of the first monomeric $\eta^{1}$-hydrazido zirconocene complex, $\mathrm{Cp}_{2} \mathrm{Zr}=\mathrm{NNPh}_{2}$. A zirconium-mediated synthesis of indoles. J. Am. Chem. Soc. 1991, 113, 6343-6345. (c) Cao, C.; Shi, Y.; Odom, A. L. Intermolecular Alkyne Hydroaminations Involving 1,1-Disubstituted Hydrazines. Org. Lett. 2002, 4, 2853-2856. (d) Li, Y.; Shi, Y.; Odom, A. L. Titanium Hydrazido and Imido Complexes: Synthesis, Structure, Reactivity, and Relevance to Alkyne Hydroamination. J. Am. Chem. Soc. 2004, 126, 1794-1803. (e) Banerjee, S.; Odom, A. L. Synthesis and Structure of a Titanium Hydrazido(2-) Complex. Organometallics 2006, 25, 3099-3101. (f) Dissanayake, A. A.; Odom, A. L. Single-step synthesis of pyrazoles using titanium catalysis. Chem. Commun. 2012, 48, 440-442. (g) Herrmann, H.; Lloret Fillol, J. L.; Wadepohl, H.; Gade, L. H. A Zirconium Hydrazide as a Synthon for a Metallanitrene Equivalent: Atom-by-Atom Assembly of $\left[\mathrm{EN}_{2}\right]_{2}$ Units $(\mathrm{E}=\mathrm{S}, \mathrm{Se})$ by Chalcogen-Atom Transfer in the Coordination Sphere of a Transition Metal. Angew. Chem., Int. Ed. 2007, 46, 8426-8430. (h) Gehrmann, T.; Lloret Fillol, J. L.; Wadepohl, H.; Gade, L. H. Assembly of an $\mathrm{R}_{3} \mathrm{~N}_{5}$ Chain by Cycloaddition of a Hydrazinediide and an Azide at Zirconium and its Thermal Fragmentation. Angew. Chem., Int. Ed. 2009, 48, 2152-2156. (i) Gehrmann, T.; Kruck, M.; Wadepohl, H.; Gade, L. H. Stitching together $\mathrm{SN}_{\mathrm{x}}$ units in the coordination sphere of zirconium: assembly of a tris(imido)sulfite and a hydrazidobis(imido)sulfite. Chem. Commun. 2012, 48, 2397-2399. (j) Gehrmann, T.; Scholl, S. A.; Fillol, J. L.; Wadepohl, H.; Gade, L. H. Alternative Reaction Pathways in Domino Reactions of Hydrazinediidozirconium Complexes with Alkynes. Chem. - Eur. J. 2012, 18, 3925-3942. (k) Blake, A. J.; McInnes, J. M.; Mountford, P.; Nikonov, G. I.; Swallow, D.; Watkin, D. J. Cycloaddition Reactions of Titanium and Zirconium Imido, Oxo and Hydrazido Complexes Supported by Tetraaza Macrocyclic Ligands. J. Chem. Soc., Dalton Trans. 1999, 379392. (1) Selby, J. D.; Manley, C. D.; Feliz, M.; Schwarz, A. D.; Clot, E.; Mountford, P. New ligand platforms for developing the chemistry of the $\mathrm{Ti}=\mathrm{N}-\mathrm{NR}_{2}$ functional group and insertion of alkynes into the $\mathrm{N}$ $\mathrm{N}$ bond of a $\mathrm{Ti}=\mathrm{N}-\mathrm{NPh}_{2}$ ligand. Chem. Commun. 2007, 4937-4939. (m) Schofield, A. D.; Nova, A.; Selby, J. D.; Manley, C. D.; Schwarz, A. D.; Clot, E.; Mountford, P. $\mathrm{M}=\mathrm{N}_{\alpha}$ cycloaddition and $\mathrm{N}_{\alpha}-\mathrm{N}_{\beta}$ insertion in the reactions of titanium hydrazido compounds with alkynes: a combined experimental and computational study. J. Am. Chem. Soc. 2010, 132, 10484-10497. (n) Tiong, P. J.; Schofield, A. D.; Selby, J. D.; Nova, A.; Clot, E.; Mountford, P. Single and double substrate insertion into the $\mathrm{Ti}=\mathrm{N}_{\alpha}$ bonds of terminal titanium hydrazides. Chem. Commun. 2010, 46, 85-87. (o) Schofield, A. D.; Nova, A.; Selby, J. D.; Schwarz, A. D.; Clot, E.; Mountford, P. Reaction site diversity in the reactions of titanium hydrazides with organic nitriles, isonitriles and isocyanates: $\mathrm{Ti}=\mathrm{N}$ cycloaddition, $\mathrm{Ti}=\mathrm{N}$ insertion and N-N bond cleavage. Chem. - Eur. J. 2011, 17, 265-285. (p) Tiong, P. J.; Nova, A.; Schwarz, A. D.; Selby, J. D.; Clot, E.; Mountford, P. Site selectivity and reversibility in the reactions of titanium hydrazides with $\mathrm{Si}-\mathrm{H}, \mathrm{Si}-\mathrm{X}, \mathrm{C}-\mathrm{X}$ and $\mathrm{H}^{+}$reagents: $\mathrm{Ti}-\mathrm{N}_{\alpha}$ 1,2-silane addition, $\mathrm{N}_{\beta}$ alkylation, $\mathrm{N}_{\alpha}$ protonation and $\sigma$-bond metathesis. Dalton Trans. 2012, 41, 2277-2288. (q) Stevenson, L. C.; Mellino, S.; Clot, E.; Mountford, P. Reactions of Titanium Hydrazides with Silanes and Boranes: $\mathrm{N}-\mathrm{N}$ Bond Cleavage and $\mathrm{N}$ Atom Functionalization. J. Am. Chem. Soc. 2015, 137, 10140-10143. (r) Tiong, P. J.; Groom, L. R.; Clot, E.; Mountford, P. Synthesis, Bonding and Reactivity of a Terminal Titanium Alkylidene Hydrazido Compound. Chem. - Eur. J. 2013, 19, 4198-4216.

(5) Wiberg, N.; Haring, H.-W.; Huttner, G.; Friedrich, P. [Bis(trimethylsilyl)isodiazen](cyclopentadienyl)metall-Komplexe: Synthese und Struktur. Chem. Ber. 1978, 111, 2708-2715.

(6) (a) Schwarz, A. D.; Nova, A.; Clot, E.; Mountford, P. Titanium alkoxyimido $(\mathrm{Ti}=\mathrm{N}-\mathrm{OR})$ complexes: reductive $\mathrm{N}-\mathrm{O}$ bond cleavage at the boundary between hydrazide and peroxide ligands. Chem. Commun. 2011, 47, 4926-4928. (b) Schwarz, A. D.; Nova, A.; Clot, E.; Mountford, P. Titanium tert-Butoxyimido Compounds. Inorg.
Chem. 2011, 50, 12155-12171. (c) Groom, L. R.; Russell, A. F.; Schwarz, A. D.; Mountford, P. Reactions of a CyclopentadienylAmidinate Titanium Benzimidamido Complex. Organometallics 2014, 33, 1002-1009. (d) Groom, L. R.; Schwarz, A. D.; Nova, A.; Clot, E.; Mountford, P. Synthesis and reactions of a cyclopentadienyl-amidinate titanium tert-butoxyimido compound. Organometallics 2013, 32, $7520-7539$.

(7) Weinhold, F.; Landis, C. R.: Valency and Bonding: A Natural Bond Orbital Donor-Acceptor Perspective; Cambridge University Press: Cambridge, 2005.

(8) (a) Selby, J. D.; Manley, C. D.; Schwarz, A. D.; Clot, E.; Mountford, P. Titanium hydrazides supported by diamide-amine and related ligands: a combined experimental and DFT study. Organometallics 2008, 27, 6479-6494. (b) Tiong, P. J.; Nova, A.; Groom, L. R.; Schwarz, A. D.; Selby, J. D.; Schofield, A. D.; Clot, E.; Mountford, $\mathrm{P}$. Reactions of cyclopentadienyl-amidinate titanium hydrazides with $\mathrm{CO}_{2}, \mathrm{CS}_{2}$ and isocyanates: $\mathrm{Ti}=\mathrm{N}$ cycloaddition, cycloaddition insertion and cycloaddition- $\mathrm{NNR}_{2}$ group transfer reactions. Organometallics 2011, 30, 1182-1201.

(9) (a) Protchenko, A. V.; Saleh, L. M. A.; Vidovic, D.; Dange, D.; Jones, C.; Mountford, P.; Aldridge, S. Contrasting reactivity of anionic boron- and gallium-containing NHC analogues: $\mathrm{E}-\mathrm{C}$ vs. $\mathrm{E}-\mathrm{M}$ bond formation ( $\mathrm{E}=\mathrm{B}, \mathrm{Ga})$. Chem. Commun. 2010, 46, 8546-8548. (b) Saleh, L. M. A.; Hassomal Birjkumar, K.; Protchenko, A. V.; Schwarz, A. D.; Aldridge, S.; Jones, C.; Kaltsoyannis, N.; Mountford, P. Group 3 and Lanthanide Boryl Compounds: Syntheses, Structures, and Bonding Analyses of Sc-B, Y-B, and Lu-B $\sigma$-Coordinated NHC Analogues. J. Am. Chem. Soc. 2011, 133, 3836-3839.

(10) Thompson, R.; Chen, C.-H.; Pink, M.; Wu, G.; Mindiola, D. J. A Nitrido Salt Reagent of Titanium. J. Am. Chem. Soc. 2014, 136, 81978200.

(11) Grant, L. N.; Pinter, B.; Kurogi, T.; Carroll, M. E.; Wu, G.; Manor, B. C.; Carroll, P. J.; Mindiola, D. J. Molecular titanium nitrides: nucleophiles unleashed. Chem. Sci. 2017, 8, 1209-1224.

(12) (a) Danopoulos, A. A.; Redshaw, C.; Vaniche, A.; WIlkinson, G.; Hussain-Bates, B.; Hursthouse, M. B. Organoimido complexes of tungsten- X-ray crystal structures of $\mathrm{W}\left(\mathrm{NC}_{6} \mathrm{H}_{11}\right) \mathrm{Cl}_{2}\left(\mathrm{PMe}_{3}\right)_{3}$, [W$\left.\left(\mathrm{NC}_{6} \mathrm{H}_{11}\right) \mathrm{Cl}_{2}\left(\mathrm{PMe}_{3}\right)_{3}\right] \mathrm{O}_{3} \mathrm{SCF}_{3}, \quad\left[\mathrm{~W}\left(\mathrm{NC}_{6} \mathrm{H}_{11}\right) \mathrm{Cl}\left(\mathrm{PMe}_{3}\right)_{4}\right] \mathrm{BPh}_{4}, \mathrm{~W}-$ $\left[\mathrm{NSi}\left(\mathrm{O}-\mathrm{MeC}_{6} \mathrm{H}_{4}\right)_{3}\right] \mathrm{Cl}_{2}\left(\mathrm{PMe}_{3}\right)_{3}, \mathrm{~W}\left[\mathrm{NB}\left(\mathrm{Mes}_{2}\right)\right]_{2} \mathrm{Cl}_{2}\left(\mathrm{PMe}_{3}\right)_{2}, \quad(\mathrm{~W}-$ $\left.(\mathrm{NPh}) \mathrm{Cl}\left[\mathrm{O}_{2} \mathrm{C}_{2}\left(\mathrm{CF}_{3}\right)_{4}\right]_{2}\right) \mathrm{Li}$ and $\mathrm{WCl}_{4}\left(\mathrm{PMe}_{2} \mathrm{Ph}\right)_{3}$. Polyhedron 1993, 12, 1061-1071. (b) Weber, K.; Korn, K.; Schorm, A.; Kipke, J.; Lemke, M.; Khvorost, A.; Harms, K.; Sundermeyer, J. Recent Advances in the Synthesis of N-Heteroatom Substituted Imido Complexes Containing a Nitrido Bridge $[\mathrm{M}=\mathrm{N}-\mathrm{E}](\mathrm{M}=$ Group 4, 5 and 6 Metal, E = B, Si, Ge, P, S). Z. Anorg. Allg. Chem. 2003, 629, $744-754$.

(13) Fryzuk, M. D.; MacKay, B. A.; Johnson, S. A.; Patrick, B. O. Hydroboration of Coordinated Dinitrogen: A New Reaction for the $\mathrm{N}_{2}$ Ligand that Results in Its Functionalization and Cleavage. Angew. Chem., Int. Ed. 2002, 41, 3709-3712.

(14) Hadlington, T. J.; Abdalla, J. A. B.; Tirfoin, R.; Aldridge, S.; Jones, C. Stabilization of a two-coordinate, acyclic diaminosilylene (ADASi): completion of the series of isolable diaminotetrylenes,:E$\left(\mathrm{NR}_{2}\right)_{2}(\mathrm{E}=$ group 14 element $)$. Chem. Commun. 2016, 52, 17171720.

(15) Clough, B. A.; Mellino, S.; Clot, E.; Mountford, P. New scandium borylimido chemistry: synthesis, bonding and reactivity. J. Am. Chem. Soc. 2017, 139, 11165-11183.

(16) (a) Bettinger, H. F. Phenylborylene: Direct spectroscopic characterization in inert gas matrices. J. Am. Chem. Soc. 2006, 128, 2534-2535. (b) Bettinger, H. F.; Bornemann, H. Donor stabilized borylnitrene: A highly reactive $\mathrm{BN}$ analogue of vinylidene. J. Am. Chem. Soc. 2006, 128, 11128-11134. (c) Bettinger, H. F. BNanalogues of vinylidene transition metal complexes: The borylnitrene isomer. Inorg. Chem. 2007, 46, 5188-5195. (d) Bettinger, H. F.; Filthaus, M.; Bornemann, H.; Oppel, I. M. Metal-free conversion of methane and cycloalkanes to amines and amides by employing a borylnitrene. Angew. Chem., Int. Ed. 2008, 47, 4744-4747. (e) Bettinger, H. F.; Filthaus, M.; Neuhaus, P. Insertion into 
dihydrogen employing the nitrogen centre of a borylnitrene. Chem. Commun. 2009, 2186-2188. (f) Filthaus, M.; Schwertmann, L.; Neuhaus, P.; Seidel, R. W.; Oppel, I. M.; Bettinger, H. F. C-H bond amination by photochemically generated transient borylnitrenes at room temperature: A combined experimental and theoretical investigation of the insertion mechanism and influence of substituents. Organometallics 2012, 31, 3894-3903. (g) Müller, M.; MaichleMössmer, C.; Bettinger, H. F. C-H functionalization of tetramethylsilane employing a borylnitrene. Chem. Commun. 2013, 49, 11773-11775.

(17) (a) Blake, A. J.; Collier, P. E.; Dunn, S. C.; Li, W.-S.; Mountford, P.; Shishkin, O. V. Synthesis and imido-group exchange reactions of tert-butylimidotitanium complexes. J. Chem. Soc., Dalton Trans. 1997, 1549-1558. (b) Dunn, S. C.; Batsanov, A. S.; Mountford, P. A general route to $\mathrm{Ti}$ imido complexes: structure of $\left[\left(\mathrm{Me}_{8} \mathrm{taa}\right) \mathrm{Ti}\left(\mathrm{NBu}^{\mathrm{t}}\right)\right]$. J. Chem. Soc., Chem. Commun. 1994, 2007-2008. (c) Adams, N.; Bigmore, H. R.; Blundell, T. L.; Boyd, C. L.; Dubberley, S. R.; Sealey, A. J.; Cowley, A. R.; Skinner, M. E. G.; Mountford, P. New Titanium Imido Synthons: Syntheses and Supramolecular Structures. Inorg. Chem. 2005, 44, 2882-2894. (d) Adams, N.; Cowley, A. R; Dubberley, S. R.; Sealey, A. J.; Skinner, M. E. G.; Mountford, P. Evaluation of the Relative Importance of $\mathrm{Ti}-\mathrm{Cl} \cdots \mathrm{H}-\mathrm{N}$ Hydrogen Bonds and Supramolecular Interactions Between Perfluorophenyl Rings in the Crystal Structures of $\left[\mathrm{Ti}(\mathrm{NR}) \mathrm{Cl}_{2}\left(\mathrm{NHMe}_{2}\right)_{2}\right]\left(\mathrm{R}={ }^{\mathrm{i}} \mathrm{Pr}\right.$, $\mathrm{C}_{6} \mathrm{H}_{5}$ or $\mathrm{C}_{6} \mathrm{~F}_{5}$ ). Chem. Commun. 2001, 2738-2739.

(18) (a) Parsons, T. B.; Hazari, N.; Cowley, A. R.; Green, J. C.; Mountford, P. Synthesis, Structures, and DFT Bonding Analysis of New Titanium Hydrazido(2-) Complexes. Inorg. Chem. 2005, 44, 8442-8458. (b) Clulow, A. J.; Selby, J. D.; Cushion, M. G.; Schwarz, A. D.; Mountford, P. Synthesis, structures and reactivity of Group 4 hydrazido complexes supported by calix[4]arene ligands. Inorg. Chem. 2008, 47, 12049-12062.

(19) Fletcher, D. A.; McMeeking, R. F.; Parkin, D. The United Kingdom Chemical Database Service. J. Chem. Inf. Comput. Sci. 1996, 36, 746-759 (The UK Chemical Database Service: CSD version 745.738 updated May 2017)..

(20) Lorber, C.; Choukroun, R; Vendier, L. A General and Facile One-Step Synthesis of Imido-Titanium(IV) Complexes: Application to the Synthesis of Compounds Containing Functionalized or Chiral Imido Ligands and Bimetallic Diimido Architectures. Eur. J. Inorg. Chem. 2006, 2006, 4503-4518.

(21) Addison, A. W.; Rao, T. N.; Reedijk, J.; van Rijn, J.; Verschoor, G. C. Synthesis, structure, and spectroscopic properties of copper(II) compounds containing nitrogen-sulphur donor ligands; the crystal and molecular structure of aqua[1,7-bis(N-methylbenzimidazol-2'-yl)2,6-dithiaheptane]copper(II). J. Chem. Soc., Dalton Trans. 1984, 13491356.

(22) Aullón, G.; Bellamy, D.; Brammer, L.; Bruton, E. A.; Orpen, A. G. Metal-bound chlorine often accepts hydrogen bonds. Chem. Commun. 1998, 653-654.

(23) Komorowski, L.; Meller, A.; Niedenzu, K. Boron nitrogencompounds. 124. Pyrazole derivatives of 9-borabicyclo[3.3.1]nonane. Inorg. Chem. 1990, 29, 538-541.

(24) (a) Owen, C. T.; Bolton, P. D.; Cowley, A. R.; Mountford, P. Cyclopentadienyl Titanium Imido Compounds and Their Ethylene Polymerization Capability: Control of Molecular Weight Distributions by Imido N-Substituents. Organometallics 2007, 26, 83-92. (b) Carmalt, C. J.; Newport, A. C.; Parkin, I. P.; White, A. J. P.; Williams, D. J. Titanium Imido complexes as precursors to titanium nitride. J. Chem. Soc., Dalton Trans. 2002, 4055-4059.

(25) Lyne, P. D.; Mingos, D. M. P. Investigation of the trans influence in transition metal nitride complexes. J. Chem. Soc., Dalton Trans. 1995, 1635-1643.

(26) Collier, P. E.; Dunn, S. C.; Mountford, P.; Shishkin, O. V.; Swallow, D. Exchange of Organoimido Groups at a Mononuclear Titanium Centre and a Crystallographic Evaluation of the Relative Structural Influences of the $\mathrm{NBu}^{t}, \mathrm{NC}_{6} \mathrm{H}_{4} \mathrm{Me}-4$ and $\mathrm{NC}_{6} \mathrm{H}_{4} \mathrm{NO}_{2}-4$ Ligands. J. Chem. Soc., Dalton Trans. 1995, 3743-3745.
(27) (a) Odom, A. L. New C-N and C-C bond forming reactions catalyzed by titanium complexes. Dalton Trans. 2005, 225-233. (b) Ciszewski, J. T.; Harrison, J. F.; Odom, A. L. Investigation of transition metal-imido bonding in $\mathrm{M}\left(\mathrm{NBu}^{\mathrm{t}}\right)_{2}$ (dpma). Inorg. Chem. 2004, 43, 3605-3617. (c) Patel, S.; Li, Y.; Odom, A. L. Synthesis, Structure, and LLCT Transitions in Terminal Hydrazido(2-) Bipyridine Complexes of Titanium. Inorg. Chem. 2007, 46, 63736381.

(28) Guiducci, A. E.; Cowley, A. R.; Skinner, M. E. G.; Mountford, P. Novel double substrate insertion versus isocyante extrusion in reactions of imidotitanium complexes with $\mathrm{CO}_{2}$ : critical dependence on imido N-substituents. J. Chem. Soc., Dalton Trans. 2001, 13921934.

(29) Bai, Y.; Noltemeyer, M.; Roesky, H. W. Synthesis and structures of monoalkylamides and monoalkylimides of titanium. Z. Naturforsch., B: J. Chem. Sci. 1991, 46, 1357-1363.

(30) (a) Guiducci, A. E.; Boyd, C. L.; Mountford, P. Reactions of cyclopentadienyl-amidinate titanium imido compounds with $\mathrm{CS}_{2}$, $\mathrm{COS}$, isocyanates and other unsaturated organic substrates. Organometallics 2006, 25, 1167-1187. (b) Guiducci, A. E.; Boyd, C. L.; Clot, E.; Mountford, P. Reactions of cyclopentadienyl-amidinate titanium imido compounds with $\mathrm{CO}_{2}$ : cycloaddition-extrusion vs. cycloaddition-insertion. Dalton Trans. 2009, 5960-5979.

(31) Coles, M. P.; Hitchcock, P. B. Exploration of the Suitability of Bicyclic Guanidinates as Ligands in Catalytic Chemistry Mediated by Titanium. Organometallics 2003, 22, 5201-5211.

(32) (a) Li, Y.; Banerjee, S.; Odom, A. L. Synthesis and Structure of (Triphenylsilyl)imido Complexes of Titanium and Zirconium. Organometallics 2005, 24, 3272-3278. (b) Majumder, S.; Gipson, K. R.; Staples, R. J.; Odom, A. L. Pyrazole Synthesis Using a TitaniumCatalyzed Multicomponent Coupling Reaction and Synthesis of Withasomnine. Adv. Synth. Catal. 2009, 351, 2013-2023.

(33) Bartlett, R. A.; Chen, H.; Rasika Dias, H. V.; Olmstead, M. M.; Power, P. P. Synthesis and Spectroscopic and Structural Characterization of the Novel Lithium Borylamide Salts trans-[ $\left[\mathrm{Li}\left(\mathrm{Et}_{2} \mathrm{O}\right)\right.$ $\left.\mathrm{NHBMes}_{2}\right]_{2}$, a Dimer, and the Ion Pair $\left[\mathrm{Li}\left(\mathrm{Et}_{2} \mathrm{O}\right)_{3}\right]\left[\mathrm{Mes}_{2} \mathrm{BNBMes}_{2}\right]$ with a Linear Allene-like, $\left[\mathrm{R}_{2} \mathrm{~B}=\mathrm{N}=\mathrm{BR}_{2}\right]^{-}$, Moiety. J. Am. Chem. Soc. 1988, 110, 446-449.

(34) Bader, R. F. W. Atoms in Molecules: A Quantum Theory; Oxford University Press: Oxford, 1990.

(35) Swallow, D.; McInnes, J. M.; Mountford, P. Titanium Imido Complexes with Tetraaza Macrocyclic Ligands. J. Chem. Soc., Dalton Trans. 1998, 2253-2259.

(36) Reed, A. E.; Curtiss, L. A.; Weinhold, F. Natural Bonding Orbital analysis. Chem. Rev. 1988, 88, 899-926.

(37) Bent, H. A. An Appraisal of Valence-bond Structures and Hybridization in Compounds of the First-row elements. Chem. Rev. 1961, 61, 275-311.

(38) (a) Dunn, S. C.; Mountford, P.; Robson, D. A. Cyclopentadienyl, indenyl and bis(cyclopentadienyl) titanium Imido compounds. J. Chem. Soc., Dalton Trans. 1997, 293-304. (b) Smith, M. R.; Matsunaga, P. T.; Andersen, R. A. Preparation of Monomeric $\left(\mathrm{Me}_{5} \mathrm{C}_{5}\right)_{2} \mathrm{VO}$ and $\left(\mathrm{Me}_{5} \mathrm{C}_{5}\right)_{2} \mathrm{Ti}(\mathrm{O})(\mathrm{L})$ and their decomposition to $\left(\mathrm{Me}_{5} \mathrm{C}_{5}\right)_{4} \mathrm{M}_{4}(\mu-\mathrm{O})_{6}$. J. Am. Chem. Soc. 1993, 115, 7049-7050. (c) Sweeney, Z. K.; Polse, J. L.; Andersen, R. A.; Bergman, R. G.; Kubinec, M. G. Synthesis, structure and reactivity of monomeric titanocene sulfido and disulfido complexes. Reaction of $\mathrm{H}_{2}$ with a terminal $\mathrm{Ti}=\mathrm{S}$ bond. J. Am. Chem. Soc. 1997, 119, 4543-4544. (d) Doxsee, K. M.; Farahi, J. B. Synthesis and reactivity of vinylimido complexes of titanocene. J. Chem. Soc., Chem. Commun. 1990, 14521454. (e) Howard, W. A.; Parkin, G. Multiple bonds between hafnium and the chalcogens: synthesis and structures of the termonal chalcogenido complexes $\left(\eta-\mathrm{C}_{5} \mathrm{Me}_{4} \mathrm{R}\right)_{2} \mathrm{Hf}(\mathrm{E})\left(\mathrm{NC}_{5} \mathrm{H}_{5}\right)(\mathrm{E}=\mathrm{O}, \mathrm{S}, \mathrm{Se}$, Te). J. Organomet. Chem. 1994, 472, C1-C4. (f) Zuckerman, R. L.; Bergman, R. G. Structural factors that influence the course of overall $[2+2]$ cycloaddition reactions between $\mathrm{Cp}_{2} \mathrm{Zr}=\mathrm{NR}$ and heterocumulenes. Organometallics 2000, 19, 4795-4809. (g) Carney, M. J.; Walsh, P. J.; Bergman, R. G. The generation of reactive intermediates $\mathrm{Cp}^{*}{ }_{2} \mathrm{Zr}=\mathrm{S}$, $\mathrm{O}$ : trapping reactions with unsaturated organic molecules 
and dative ligands. J. Am. Chem. Soc. 1990, 112, 6426-6428. (h) Walsh, P. J.; Baranger, A. M.; Bergman, R. G. Stoichiometric and catalytic hydroammination of alkynes and allene by zirconium $\mathrm{Cp}_{2} \mathrm{Zr}(\mathrm{NHR})_{2}$. J. Am. Chem. Soc. 1992, 114, 1708-1719. (i) Hou, Z.; Breen, T. L.; Stephan, D. W. Formation and reactivity of the early metal phosphides and phosphinidenes $\mathrm{Cp}^{*}{ }_{2} \mathrm{Zr}=\mathrm{PR}, \mathrm{Cp}^{*}{ }_{2} \mathrm{Zr}(\mathrm{PR})_{2}$ and $\mathrm{Cp}_{2}{ }_{2} \mathrm{Zr}(\mathrm{PR})_{3}$. Organometallics 1993, 12, 3158-3167. (j) Baranger, A. M.; Walsh, P. J.; Bergman, R. G. Variable regiochemistry in the stoichiometric and catalytic hydroamination of alkynes by imidozirconium complexes caused by an unusual dependence of the rate law on alkyne structure and temperature. J. Am. Chem. Soc. 1993, 115, 27532763. (k) Howard, W. A.; Waters, M.; Parkin, G. Terminal zirconium oxo complexes: synthesis, structure and reactivity of $\left(\mathrm{C}_{5} \mathrm{Me}_{4} \mathrm{R}\right)_{2} \mathrm{Zr}$ (O) $\left(\mathrm{NC}_{5} \mathrm{H}_{4} \mathrm{R}^{\prime}\right)$. J. Am. Chem. Soc. 1993, 115, 4917-4918. (1) Howard, W. A.; Parkin, G. Terminal oxo, sulfido, selenido and tellurido complexes of zirconium, $\left(\eta-\mathrm{C}_{5} \mathrm{Me}_{4} \mathrm{R}\right){ }_{2} \mathrm{Zr}(\mathrm{E})\left(\mathrm{NC}_{5} \mathrm{H}_{5}\right)$ : Comparison of $\mathrm{Zr}-\mathrm{E}$ single and $\mathrm{Zr}$ :E double bond lengths. J. Am. Chem. Soc. 1994, 116, 606-615. (m) Sweeney, Z. K.; Polse, J. L.; Bergman, R. G.; Andersen, R. A. Dihydrogen Activation by Titanium Sulfide Complexes. Organometallics 1999, 18, 5502-5510.

(39) Polse, J. L.; Andersen, R. A.; Bergman, R. G. Reactivity of a terminal $\mathrm{Ti}(\mathrm{IV})$ imido complex towards alkenes and alkynes: cycloaddition vs C-H activation. J. Am. Chem. Soc. 1998, 120, 13405-13414.

(40) Haehnel, M.; Ruhmann, M.; Theilmann, O.; Roy, S.; Beweries, T.; Arndt, P.; Spannenberg, A.; Villinger, A.; Jemmis, E. D.; Schulz, A.; Rosenthal, U. Reactions of Titanocene Bis(trimethylsilyl)acetylene Complexes with Carbodiimides: An Experimental and Theoretical Study of Complexation versus C-N Bond Activation. J. Am. Chem. Soc. 2012, 134, 15979-15991.

(41) Hermanek, S. ${ }^{11}$ B NMR Spectra of Boranes, Main-Group Heteroboranes, and Substituted Derivatives. Factors Influencing Chemical Shifts of Skeletal Atoms. Chem. Rev. 1992, 92, 325-362.

(42) Doxsee, K. M.; Garner, L. C.; Juliette, J. J. J.; Mouser, J. K. M.; Weakley, J. R.; Hope, H. Titanocene Imido Complexes: Generation as Reactive Intermediates, Isolation, and Structural Characterization. Tetrahedron 1995, 51, 4321-4332.

(43) (a) Anhaus, J. T.; Kee, T. P.; Schofield, M. H.; Schrock, R. R. Planar "20-electron" osmium imido complexes. A linear imido ligand does not necessarily donate its lone pair of electrons to the metal. $J$. Am. Chem. Soc. 1990, 112, 1642-1643. (b) Schofield, M. H.; Kee, T. P.; Anhaus, J. T.; Schrock, R. R.; Johnson, K. H.; Davis, W. M. Osmium imido complexes: synthesis, reactivity, and SCF-X $\alpha$-SW electronic structure. Inorg. Chem. 1991, 30, 3595-3604. (c) Benson, M. T.; Bryan, J. C.; Burrell, A. K.; Cundari, T. R. Bonding and structure of heavily $\pi$-loaded complexes. Inorg. Chem. 1995, 34, 23482355. (d) Morrison, D. L.; Wigley, D. E. Multiple-imido complexes of molybdenum: synthesis and reactivity of the $\mathrm{d}^{0} \mathrm{Mo}(=\mathrm{NR})_{3}$ functional group. Inorg. Chem. 1995, 34, 2610-2616. (e) Benson, M. T.; Cundari, T. R.; Moody, E. W. Methane activations by tris(imido) complexes: the effect of metal, ligand and d orbital occupation. J. Organomet. Chem. 1995, 504, 1-3.

(44) (a) Glueck, D. S.; Green, J. C.; Michelman, R. I.; Wright, I. N. Study of Metal-Ligand Multiple Bonding in Osmium and Iridium Imido Complexes: Evidence for the Cyclopentadienyl-Imido Analogy. Organometallics 1992, 11, 4221-4225. (b) Williams, D. S.; Schofield, M. H.; Anhaus, J. T.; Schrock, R. R. Synthesis and reactions of tungsten(IV) bis(imido) complexes: relatives of bent metallocenes. J. Am. Chem. Soc. 1990, 112, 6728-6729.

(45) Crabtree, R. H.: The Organometallic Chemistry of the Transition Metals, 4th ed.; Wiley Blackwell: London, 2005.

(46) (a) Green, J. C. Bent metallocenes revisted. Chem. Soc. Rev. 1998, 27, 263-271. (b) Silavwe, N. D.; Bruce, M. R. M.; Philbin, C. E.; Tyler, D. R. Descriptive Photochemistry and Electronic Structure of the $\mathrm{Cp}_{2} \mathrm{MoO}$ and $(\mathrm{MeCp})_{2} \mathrm{MoO}$ Complexes $\left(\mathrm{Cp}=\eta^{5}-\mathrm{C}_{5} \mathrm{H}_{5} ; \mathrm{MeCp}\right.$ $\left.=\eta^{5}-\mathrm{CH}_{3} \mathrm{C}_{5} \mathrm{H}_{4}\right)$. Inorg. Chem. 1988, 27, 4669-4676. (c) Green, J. C.; Green, M. L. H.; James, J. T.; Konidaris, P. C.; Maunder, G. H.; Mountford, P. Bis $(\eta$-cyclopentadienyl)-molybdenum and -tungsten lmido Complexes: X-Ray Structures of $\left[\mathrm{Mo}\left(\eta-\mathrm{C}_{5} \mathrm{H}_{5}\right)_{2}\left(\mathrm{NBu}^{\mathrm{t}}\right)\right]$ and
$\left[\mathrm{Mo}\left(\eta \mathrm{C}_{5} \mathrm{H}_{4} \mathrm{Me}\right)_{2}\left(\mathrm{NBu}^{\mathrm{t}}\right) \mathrm{Me}\right] \mathrm{I}$. J. Chem. Soc., Chem. Commun. 1992, 1361-1365. (d) Jorgensen, K. A. MO explanation of the "unexpected" structure of $\left(\eta^{5}-\mathrm{C}_{5} \mathrm{Me}_{5}\right)_{2} \mathrm{Ta}\left(=\mathrm{NC}_{6} \mathrm{H}_{5}\right) \mathrm{H}$. Inorg. Chem. 1993, 32, 1521-1522. (e) Hanna, T. E.; Keresztes, I.; Lobkovsky, E.; Bernskoetter, W. H.; Chirik, P. J. Synthesis of a Base-Free Titanium Imido and a Transient Alkylidene from a Titanocene Dinitrogen Complex. Organometallics 2004, 23, 3448-3458. (f) Bridgeman, A. J.; Davis, L.; Dixon, S. J.; Green, J. C.; Wright, I. N. Electronic Structure of 20-electron bis(cyclopentadienyl)-metal oxo compounds of group 6: Investigation by photoelectron spectroscopy. J. Chem. Soc., Dalton Trans. 1995, 1023-1027. (g) Hanna, T. E.; Lobkovsky, E.; Chirik, P. J. Dihydrogen and Silane Addition to Base-Free, Monomeric Bis(cyclopentadienyl)titanium Oxides. Inorg. Chem. 2007, 46, 23592361. (h) Luo, L.; Lanza, G.; Fragaia, I. L.; Stern, C. L.; Marks, T. J. Energetics of metal-ligand multiple bonds. A combined solution and thermochemical and $a b$ initio quantum chemical study of $M=O$ bonding in group 6 metallocene oxo complexes. J. Am. Chem. Soc. 1998, 120, 3111-3122.

(47) Lauher, J. W.; Hoffmann, R. Structure and chemistry of bis(cyclopentadienyl)-ML ${ }_{n}$ complexes. J. Am. Chem. Soc. 1976, 98, $1729-1742$

(48) Marsella, J. A.; Folting, K.; Huffman, J. C.; Caulton, K. G. Transition-Metal-Mediated Hydrogenation of $\mathrm{CO}$ to Olefins: Intermediacy of Coordinated Carbenes. J. Am. Chem. Soc. 1981, 103, 5596-5598.

(49) (a) Lu, E.; Li, Y.; Chen, Y. A scandium terminal imido complex: synthesis, structure and DFT studies. Chem. Commun. 2010, 46, 4469-4471. (b) Scott, J.; Basuli, F.; Fout, A. R.; Huffman, J. C.; Mindiola, D. J. Evidence for the existence of a terminal imidoscandium compound: Intermolecular $\mathrm{C}-\mathrm{H}$ activation and complexation reactions with the transient $\mathrm{Sc}=\mathrm{NAr}$ species. Angew. Chem., Int. Ed. 2008, 47, 8502-8505. (c) Mountford, P.; Ward, B. D. Recent developments in the non-cyclopentadienyl organometallic and related chemistry of scandium. Chem. Commun. 2003, 1797-1803. 